Isabella França Ferreira

Perspectivas maternas sobre separar ou não gêmeos na escola: uma abordagem psicoetológica das causas e consequências 



\section{Isabella França Ferreira}

\section{Perspectivas maternas sobre separar ou não gêmeos na escola: uma abordagem psicoetológica das causas e consequências}

\section{Versão Original}

Dissertação apresentada ao Instituto de Psicologia da Universidade de São Paulo para a obter o título de Mestre em Ciências

Área de concentração: Psicologia Experimental

Orientadora: Profa. Dra. Emma Otta

São Paulo

2020 
AUTORIZO A REPRODUÇÃO E DIVULGAÇÃO TOTAL OU PARCIAL DESTE TRABALHO, POR QUALQUER MEIO CONVENCIONAL OU ELETRÔNICO, PARA FINS DE ESTUDO E PESQUISA, DESDE QUE CITADA A FONTE.

Catalogação na publicação Biblioteca Dante Moreira Leite

Instituto de Psicologia da Universidade de São Paulo

Dados fornecidos pelo(a) autor(a)

França Ferreira, Isabella

Perspectivas maternas sobre separar ou não gêmeos na escola: uma abordagem psicoetológica das causas e consequências / Isabella França Ferreira; orientadora Emma Otta. -- São Paulo, 2020.

$112 \mathrm{f}$.

Dissertação (Mestrado - Programa de Pós-Graduação em Psicologia Experimental) -- Instituto de Psicologia, Universidade de São Paulo, 2020.

1. gêmeos na escola. 2. separação de gêmeos. 3. relacionamento entre gêmeos. 4. criação de gêmeos. 5. educação. I. Otta, Emma, orient. II. Título. 
Nome: Ferreira, Isabella França

Título: Perspectivas maternas sobre separar ou não gêmeos na escola: uma abordagem psicoetológica das causas e consequências

Dissertação apresentada ao Instituto de Psicologia da Universidade de São Paulo para obtenção do título de Mestre em Psicologia

Aprovada em:

Banca examinadora

Prof. Dr.

Instituição:

Julgamento:

Prof. Dr.

Instituição:

Julgamento:

Prof. Dr.

Instituição:

Julgamento: 



\section{Agradecimentos}

Agradeço a minha mãe, Andrea Cristina Souza França, minha fortaleza e porto seguro, pelo amor, cuidado e apoio imensuráveis, pelo coração incansável, por sempre acreditar e incentivar os meus sonhos e por ser o exemplo da mulher que busco ser. Agradeço meu pai, Fabio da Silva Ferreira, por todo o amor e suporte, por ser exemplo de determinação e por me inspirar a ser uma profissional competente, sem perder de vista as minhas origens. Vocês são a melhor parte de mim, sou eternamente grata a vocês!

Aos meus irmãos, Daniel, Luana e Manuela, meus grandes amores, que iluminam minha vida e me ensinam tanto desde que nasceram.

Às minhas avós, Idalina e Nilza, e meu avô, Nelson (in memoriam), por serem exemplos de pessoas fortes, guerreiras e integras, que eu amo demais. Aos grandes presentes que a vida me deu: meu "paidrasto", Gilberto, por ser essa pessoa tão benevolente, incrível e presente e Bruna, minha irmã de coração, por toda a cumplicidade e por compartilhar comigo o sonho da vida acadêmica. A todos os meus tios, tias, primos e primas que sempre acreditaram em mim. Aos meus sogros, Vanessa e todos os familiares que estiveram ao meu lado.

Ao meu namorado, Rodolfo, que acompanhou de perto todo o processo de construção e realização desse trabalho, por discutir horas e horas sobre minhas ideias, por revisar minha escrita e ser tão paciente e incrível. Obrigada por trilhar essa caminhada ao meu lado e por sempre incentivar os meus sonhos!

Aos meus queridos amigos Ana Ruiz, Jacu, Jacques, Santos, Moto, Lídia, Luís, Caio, Ingrid, Thay, Gurgi, Preto, Meme e tantos outros, que de longe ou de perto, contribuíram para a minha trajetória.

À minha orientadora, Profa. Dra. Emma Otta, pessoa de extrema importância na minha formação, por ter me recebido tão bem na USP, por ter apresentado os estudos com etologia humana e gêmeos, pela sua confiança no meu trabalho e por ter proporcionado ótimas oportunidades durante o mestrado que me ensinaram e amadureceram muito como profissional e cientista.

À Profa. Dra. Briseida Dôgo Resende por ter feito excelentes contribuições em minha qualificação, por ter me apresentado novas teorias e perspectivas, sempre tão solicita e atenciosa, e por ter ministrado, junto com a Profa. Dra. Ronara Ferreira-Châline, a disciplina de Motivação e Emoção na qual participei como bolsista PAE e que foi uma das experiências mais especiais e gratificantes que vivenciei no mestrado. À Dra. Ana Carla Crispim, pela 
amizade, pelas contribuições em minha qualificação, pelo suporte em minhas análises e por ter despertado em mim o interesse por aprender estatística.

A todos os colegas de laboratório que proporcionaram momentos inesquecíveis de cafés, almoços, eventos, karaokês, reuniões e risadas, que ajudaram e ensinaram tanto: Eloísa, por sua parceria e apoio de todas as horas; Paulinha, por sua postura e inteligência interpessoal; Tania, por sua paciência e prontidão; Renata, por sua vontade de fazer diferente; Matheus, por sua sagacidade; Lucas, por sua companhia desde que ingressamos juntos; todos os alunos de Iniciação Científica, Vinícius, Ricardo e Andreia.

À todas as mães que se dispuseram a participar e viabilizaram a realização desta pesquisa. Agradeço a MeTwo (antiga Confraria de Mães de Gêmeos do Rio Grande do Sul) pela divulgação e parceria. Agradeço também ao CNPq pelo financiamento da minha pesquisa. 


\section{RESUMO}

Ferreira, I.F. (2020) Perspectivas maternas sobre separar ou não gêmeos na escola: uma abordagem psicoetológica das causas e consequências (Dissertação de Mestrado). Instituto de Psicologia, Universidade de São Paulo, São Paulo.

Esta dissertação objetivou verificar as causas e consequências da decisão de manter ou separar gêmeos em diferentes salas de aula, segundo a perspectiva materna. Foram realizados três estudos com abordagens quantitativas e qualitativas e os resultados foram interpretados com base na perspectiva psicoetológica. O Estudo 1 visou obter um panorama geral da situação escolar dos gêmeos e das crenças e práticas maternas sobre gêmeos na escola. Participaram deste estudo 287 mães de gêmeos, de 2 a 10 anos de idade, que responderam ao Questionário de Zigosidade e de Gêmeos na Escola. Como resultado, 65\% dos gêmeos estudavam na mesma sala e a maioria das mães reportaram ter participado da decisão de separar ou não seus filhos, especialmente em escolas particulares. Em relação a prática, mães que moravam em cidades grandes optavam mais pela separação, assim como as de alta renda. Além disso, gêmeos mais novos eram menos separados do que os mais velhos. Em relação às crenças maternas, o relacionamento e a idade das crianças foram considerados fatores importantes para a decisão de separar ou não. Desenvolvimento da individualidade e personalidade, imposição escolar, dominância, conflito e dependência entre gêmeos foram descritos como os principais motivos a favor da separação. Não encontramos relação entre zigosidade e a prática de separação. $\mathrm{O}$ Estudo 2 buscou compreender a influência da zigosidade, idade e situação escolar no relacionamento entre gêmeos e as reações deles à separação. Foram analisadas 422 respostas de mães de gêmeos, de 4 a 12 anos, ao Questionário de Relacionamento entre Gêmeos. Pares monozigóticos (MZ) foram considerados mais dependentes do que pares dizigóticos (DZ), resultado que vai ao encontro de estudos anteriores. Pares de 4 a 6 anos que estudavam separados apresentavam mais rivalidade do que aqueles que estudavam juntos. Ainda, MZ entre 6 e 9 anos que estudavam separados eram mais dominantes do que os que estudavam juntos nesta mesma idade. Foi hipotetizado que a rivalidade e dominância já existiam previamente e, como uma maneira de reduzi-las, as mães optaram pela separação. Elas também reportaram que, dentro de um mesmo par, um gêmeo pode gostar ou querer ficar separado, enquanto o outro pode não aceitar, o que ajuda a desconstruir estereótipos de que gêmeos são uma unidade com gostos e vontades iguais. Por fim, o Estudo 3 objetivou comparar a opinião das mães quanto às consequências de se estudar junto ou separado. Para isso, comparamos as respostas de quatro grupos de mães de gêmeos: $M Z$ que estudam juntos $(n=81)$, MZ que estudavam separados $(n=45)$, DZ que estudavam juntos $(n=104)$ e DZ que estudavam separados $(n=55)$. Os que estudavam juntos apresentaram maior bem-estar, melhor relação entre eles e maior satisfação do que os que estudavam separados, independentemente da zigosidade. A presença do irmão parece fornecer suporte emocional e um porto seguro para as crianças explorarem o ambiente. Por sua vez, gêmeos que estudavam separados apresentaram maior individualidade. Não encontramos diferenças em relação a relatos das mães sobre desempenho escolar e sociabilidade. Em conclusão, a decisão frente à situação escolar é um reflexo das crenças parentais sobre a criação de gêmeos que são influenciadas pela cultura, características das mães, dos filhos e do relacionamento entre gêmeos. Este estudo foi um primeiro passo para conhecer o tema na realidade brasileira. É necessário atenção e sensibilidade por parte das escolas em relação a este público, considerando as consequências psicológicas e educacionais que práticas pouco embasadas podem acarretar.

Palavras-chave: gêmeos na escola, separação de gêmeos, relacionamento entre gêmeos, criação de gêmeos, educação 



\begin{abstract}
This dissertation aimed to verify the causes and consequences of the decision of keeping or separating twins in different classrooms, according to their mother's perspective. Three studies were carried out using quantitative and qualitative approaches and the results were interpreted according to the psychoethological perspective. The First Study focused to obtain an overview of the twins' classroom placement and the maternal's practices and beliefs about twins at school. two hundred and eighty-seven mothers of twins, from 2 to 10 years old, participated in this study and answered the Zygosity and Twins at School Questionnaire. We found that 65\% of twins studied in the same classroom and the majority of mothers reported to have participated in the decision of separating or not their children, especially in private schools. Focusing on parental practices, mothers that lived in big cities chose more often for the separation, as well as mothers with high income. Besides that, younger twins were less separated than older ones. Regarding maternal beliefs, the relationship and age of the children were considered important factor for the decision of separating or not. Individuality and personality's development, school imposition, dominance, conflict and dependency between twins were reported as being the main reasons for separation. The Second Study investigated the influence of zygosity, age and classroom placement on the twins' relationship and their reaction towards separation. The answers of 422 mothers of twins, from 4 to 12 years old, to the Twin Relationship Questionnaire were analyzed. Monozygotic pairs (MZ) were considered more dependent than dizygotic pairs (DZ), a result that is in line with findings of previous studies. Separated 4 to 6 years old pairs presented more rivalry than the ones that studied together. Furthermore, 6 to 9 years old separated MZ twins were more dominant than the ones that studied together in this age range. It was hypothesized that rivalry and dominance already existed and, as a way to minimize them, the mothers chose to separate the siblings. They also reported that, on the same pair, one twin could want to stay separated while the other could not accept it, which helps to question stereotypes of twins being one unity with the same tastes and wills. Finally, the Third Study aimed to compare the opinions of mothers in relation to the consequences of studying together or separated. For this, we compared the answers of four groups of twins' mothers: MZ that studied together $(n=81), M Z$ that studied separated $(n=45), D Z$ that studied together $(n=104)$ and DZ that studied separated $(n=55)$. Those that studied together presented greater well-being, better relationship with each other and were more satisfied than those that studied separated, independently of their zygosity. The presence of the sibling seems to offer emotional support and a safe place for the individuals to explore the environment. However, twins that studied separated presented more individuality. We did not find differences in the mothers' reports for school performance and sociability. In conclusion, the decision towards classroom placement is a reflection of parental beliefs about raising twins that are influenced by culture, characteristics of mothers, children and the twins' relationship. This study was a first step to understand the theme in Brazil. Attention and sensibility from schools is necessary towards this public, considering the psychological and educational consequences that poorly grounded practices can cause.
\end{abstract}

Key-words: twins at school, twins separation, twins relationship, twins raising, education 



\section{Lista de Figuras}

Figura 1. Práticas escolares sobre separação de gêmeos na escola

Figura 2. Fatores que influenciam a decisão de separar ou não os gêmeos em salas distintas 50

Figura 3. Porcentagem de gêmeos que estudam juntos e separados em cidades de pequeno, médio e grande porte

Figura 4. Escores médios de dominância para gêmeos MZ que estudam juntos e separados de acordo com a faixa-etária

Figura 5. Análise de similitude da reação à separação e ao reencontro de gêmeos que estudam juntos

Figura 6. Análise de similitude da reação à separação e ao reencontro de gêmeos que estudam separados

Figura 7. Percepção das mães quanto ao bem-estar de gêmeos $\mathrm{MZ}$ e $\mathrm{DZ}$ que estudam juntos e separados

Figura 8. Percepção das mães quanto ao desenvolvimento da personalidade de gêmeos MZ e DZ que estudam juntos e separados

Figura 9. Análise de similitude dos pontos positivos e negativos de se estudar junto segundo a percepção materna .81

Figura 10. Análise de similitude dos pontos positivos e negativos de se estudar separado segundo a percepção materna 



\section{Lista de Tabelas}

Tabela 1. Coeficientes de parentesco

Tabela 2. Dados sociodemográficos das respondentes do Estudo 1

Tabela 3. Características dos pares de gêmeos do Estudo 1 45

Tabela 4. Média, mediana e desvio padrão dos fatores que influenciam a decisão materna de separar ou não os gêmeos em salas distintas

Tabela 5. Número de pares na mesma sala e em salas diferentes de acordo com a zigosidade, sexo e ano escolar....

Tabela 6. Dados sociodemográficos das respondentes do Estudo 2

Tabela 7. Dados sociodemográficos das respondentes do Estudo 3

Tabela 8. Características dos pares de gêmeos do Estudo 3 



\section{Sumário}

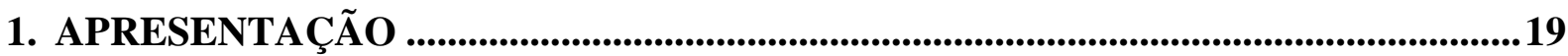

2. INTRODUÇÃO GERAL ............................................................................................................21

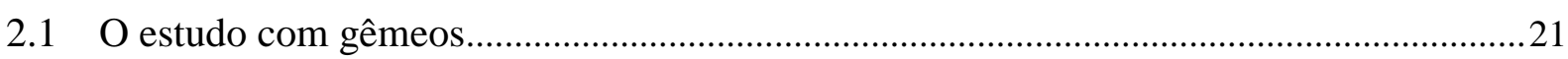

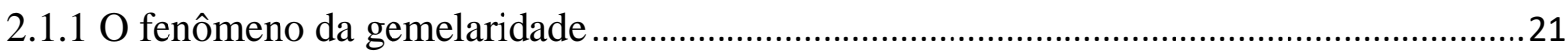

2.1.2 Tipos de estudos com gêmeos e sua importância..............................................................23

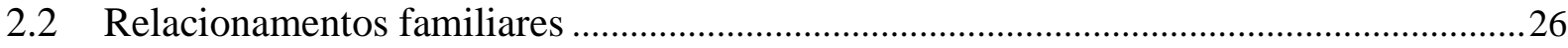

2.2.1 Perspectiva evolucionista dos relacionamentos familiares ..............................................26

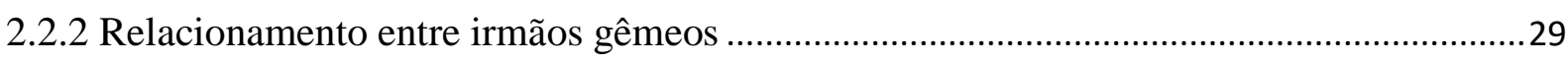

2.2.3 Crenças e práticas maternas de criação em gêmeos ............................................................31

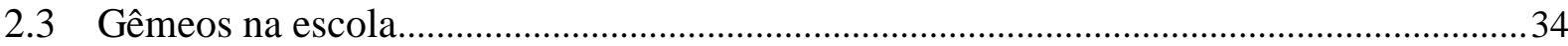

2.3.1 Importância da escola para o desenvolvimento e bem-estar infantil..................................34

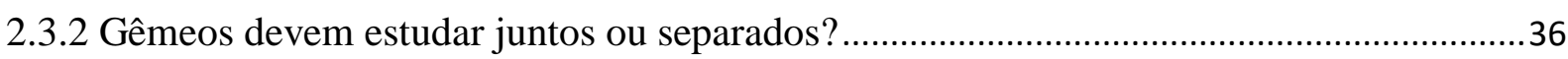

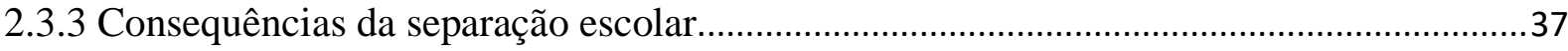

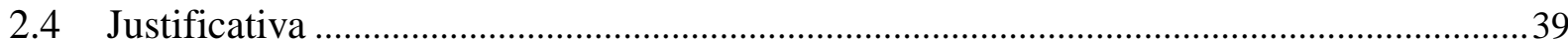

3. ESTUDO 1 - Crenças e práticas maternas sobre gêmeos na escola .............................41

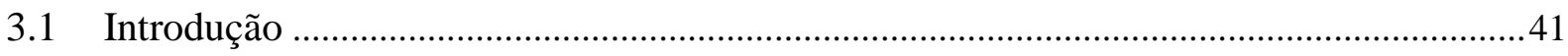

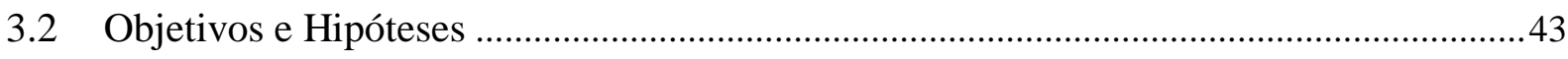

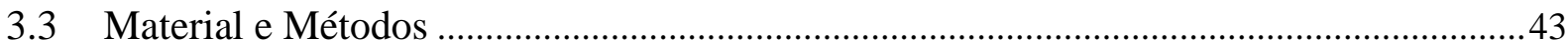

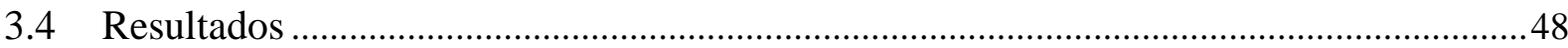

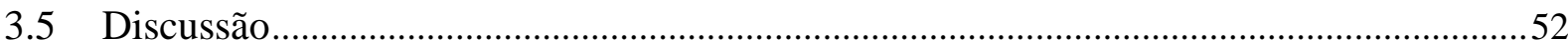

4. ESTUDO 2 - Relacionamento entre gêmeos e sua interface com a separação escolar ... 56

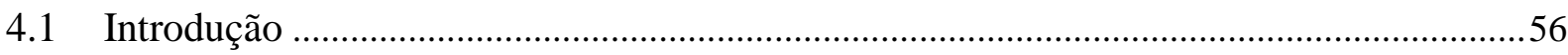

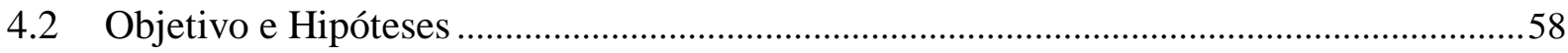

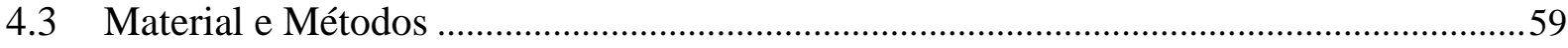

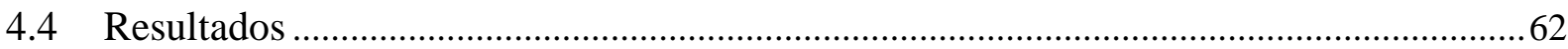

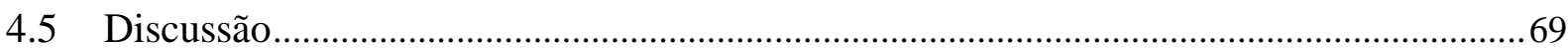

5. ESTUDO 3 - Consequências da separação de gêmeos na escola sob a perspectiva

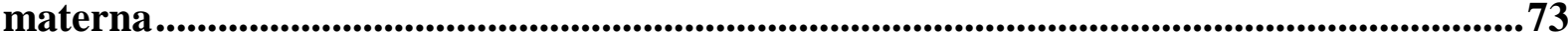

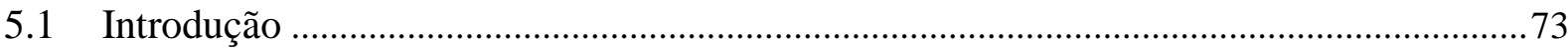

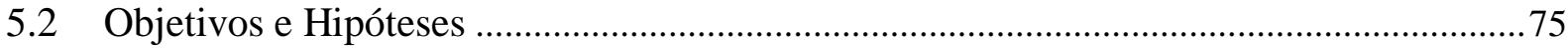




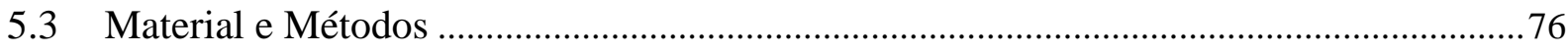

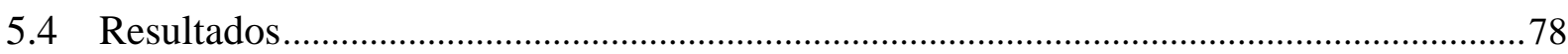

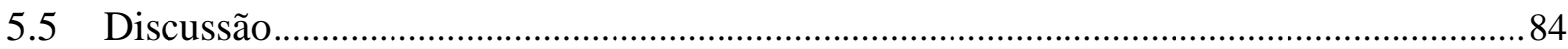

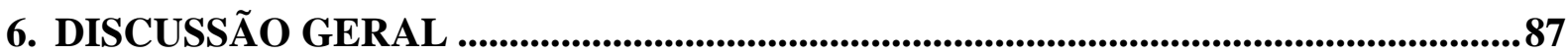

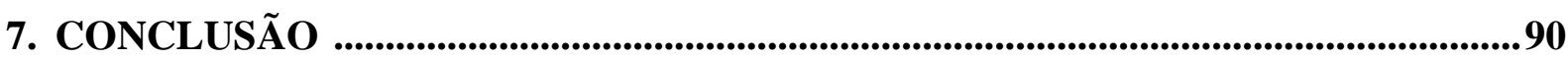

REFERÊNCIAS BIBLIOGRÁFICAS ........................................................................92

APÊNDICE A - Questionário de zigosidade adaptado para responsáveis de gêmeos baseado

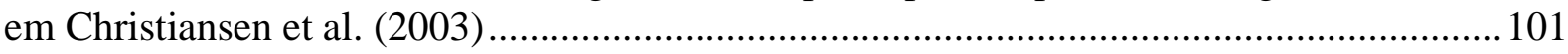

APÊNDICE B - Questionário de gêmeos na escola para responsáveis ................................. 102

APÊNDICE C - Twin Relationship Questionnaire criado por Fortuna, Goldner e Knafo (2010), traduzido e adaptado para o português...................................................................... 106

ANEXO A - Parecer Consubstanciado do CEP (Gêmeos na escola) .................................... 107

ANEXO B - Parecer consubstanciado do CEP (Relacionamento entre gêmeos e reações à separação) 


\section{APRESENTAÇÃO}

Este estudo é parte do Painel USP de Gêmeos, fundado em 2017 sob coordenação da Profa. Dra. Emma Otta do Instituto de Psicologia da Universidade de São Paulo. O Painel USP de Gêmeos é um cadastro de participação facultativa que objetiva pesquisar o comportamento, processos psicológicos em gêmeos e questões de interesse desse grupo. Atualmente o Painel tem diversas parcerias, destacando-se a Dra. Nancy Segal, professora e pesquisadora da California State University, em Fullerton, diretora do Twin Studies Center, e uma das principais referências em pesquisa com gêmeos e o Dr. Ariel Knafo-Noam professor e pesquisador da Hebrew University of Jerusalem, em Israel, que tem extensa experiência com temas como desenvolvimento infantil e estudos sobre família.

Além da produção científica, o Painel procura engajar-se com seu público através das redes sociais ( site $^{1}$, Facebook $^{2}$ e Instagram ${ }^{3}$ ) e promove encontros anuais de gêmeos desde 2016. Nestes eventos há a divulgação das pesquisas realizadas e também atividades recreativas como: shows circenses e musicais, brincadeiras para as crianças e rodas de conversa de gêmeos e mães e pais de gêmeos. As rodas de conversa permitem que o grupo de pesquisa conheça as curiosidades, preocupações, peculiaridades e demandas dos gêmeos e de suas famílias e é uma atividade muito esperada por eles. Ainda, o Painel conta com o braço clínico coordenado pela Professora Maria Lívia Tourinho Moretto do Instituo de Psicologia da USP onde é oferecido atendimento clínico psicológico aos interessados no Centro Escola de Psicologia.

A ideia do presente projeto partiu do interesse de estudar as peculiaridades de ser gêmeo, tanto para os próprios gêmeos, quanto para as famílias e instituições que os recebem. Além disso, através dos eventos e redes sociais do Painel USP de Gêmeos, frequentemente recebemos dúvidas e preocupações acerca da criação dos gêmeos, tais como a prática de separar ou não os filhos nos anos escolares iniciais, uma vez que as decisões apresentam pouco embasamento científico e são fundamentadas em mitos e senso comum, inclusive por parte de profissionais como médicos, psicólogos e professores. Tendo essa demanda como ponto de partida, fizemos uma extensa revisão da literatura e percebemos que o tema não é muito estudado no Brasil e que há falta de estudos atuais.

\footnotetext{
${ }^{1}$ Disponível em: https://www.paineluspdegemeos.com.br

${ }^{2}$ Disponível em: https://www.facebook.com/PainelUSPdeGemeos/

${ }^{3}$ Disponível em: https://www.instagram.com/paineluspgemeos/
} 
Dessa forma, tal estudo torna-se fundamental, especialmente considerando-se o aumento crescente da taxa de natalidade de gêmeos no Brasil (Cardoso-dos-Santos et al., 2018; Otta et al., 2016; Varella et al., 2018) e, portanto, a presença cada vez mais frequente deste público nas escolas brasileiras. Não pretendemos generalizar se os pais devem separar seus gêmeos ou não, uma vez que estudos apontam que esta escolha deve ser realizada considerando cada caso em particular (e.g. Hay \& Preedy, 2006; Tully et al., 2004; van Leeuwen et al., 2005). Nossa real pretensão é entender como esta decisão está sendo tomada no Brasil, suas motivações e consequências para os gêmeos, para a família e para a escola.

Seguindo as diretrizes de apresentação de dissertações e teses da USP e as normas do programa de pós-graduação em Psicologia Experimental do Instituto de Psicologia desta universidade, a dissertação foi estruturada em três capítulos em formato de periódicos científicos, aliados à introdução e discussão geral. Na introdução geral, descrevemos o panorama teórico no qual nos embasamos, inicialmente falando sobre o fenômeno da gemelaridade e os estudos realizados com gêmeos, seguido pela perspectiva etológica dos relacionamentos familiares em gêmeos e pelos trabalhos realizados sobre esse público na escola e, por último, apresentamos a justificativa e o objetivo geral da pesquisa.

Os três capítulos seguintes correspondem aos estudos realizados e têm suas próprias introduções, objetivos, métodos, resultados e discussões. São eles:

Estudo 1 - Crenças e práticas maternas sobre gêmeos na escola

Estudo 2 - Relacionamento entre gêmeos e sua interface com a separação escolar

Estudo 3 - Consequências da separação dos gêmeos na escola sob a perspectiva materna

Por fim, realizaremos uma discussão geral interligando os três estudos e realizando uma reflexão integrativa. 


\section{INTRODUÇÃO GERAL}

\subsection{O estudo com gêmeos}

\subsubsection{O fenômeno da gemelaridade}

Gêmeos dizigóticos (DZ), também conhecidos como bivitelinos ou fraternos, são formados quando, durante a ovulação, dois ovócitos ou mais são expelidos, fecundados e gerados juntos. Por serem derivados de ovócitos e espermatozoides distintos, podem ser tanto do mesmo sexo como de sexos diferentes e a sua semelhança genética não é maior do que a de irmãos não-gêmeos. Na maioria das vezes, os pares DZ apresentam diferentes placentas e anexos embrionários (Beiguelman, 2008).

Já os gêmeos idênticos ou monozigóticos (MZ) são formados de 1 a 14 dias após a fecundação de um único ovócito e espermatozoide, quando o zigoto sofre um desenvolvimento irregular. Por isso são como clones naturais, $100 \%$ idênticos na combinação genética única herdada dos pais e serão sempre do mesmo sexo. Entretanto, o ambiente de desenvolvimento intrauterino não é necessariamente tão semelhante assim. Cerca de $30 \%$ destes pares se originam aproximadamente três dias após a fecundação, quando o zigoto ainda não foi implantado no útero, por isso a diferenciação celular é maior, sendo mais provável a formação de anexos embrionários distintos e placentas também distintas. Os outros $70 \%$ dos pares serão resultado de alterações do $4^{\circ}$ ao $14^{\circ}$ dia após a fecundação. Quanto mais tardias forem estas alterações, maior a probabilidade de formação de apenas uma placenta e um conjunto em comum de anexos embrionários para ambos os gêmeos (Beiguelman, 2008).

Apesar de pouco frequente, há casos de gemelaridade em primatas como chimpanzés (Pan troglodytes) (Ely et al., 2006), macacos japoneses (Macaca Fuscata) (Sugiyama, Kurita, Matsui \& Shimomura, 2011), orangotangos (Pongo pygmaeus) (Goossens, Kapar, Kahar \& Ancrenaz, 2012) e gorilas (Gorilla gorila) (Rosen, 1972). Já em calitriquídeos, a gemelaridade é extremamente comum. Características como tamanho do indivíduo, período de gestação, cuidado paterno, maturação da ninhada e tipo de dieta influenciam na gestação múltipla. Os saguis (Callithrix jacchus) atendem a maioria destas características: são pequenos, tem um 
período gestacional curto, sua ninhada é desmamada rapidamente, adotam uma dieta diversificada (frutas e insetos) e contam com o cuidado paterno, resultando em altas taxas gemelares nesta espécie (Chapman et al., 1990).

O nascimento de dois filhotes ao mesmo tempo é mais incomum para os seres humanos e, por causa dessa raridade, algumas culturas desenvolveram diferentes rituais e mitos em relação aos gêmeos. Enquanto algumas sociedades matavam um ou ambos os gêmeos, em outras eles eram considerados "sagrados" (Bacon, 2010). Por exemplo, os Yamba de Camarões, na África, acreditam que quando os gêmeos choram muito ou um gêmeo ganha mais peso do que o outro, isso significa que eles estão presos em um estado de rivalidade. A tribo acredita que à medida que os gêmeos envelhecem nesta rivalidade, o gêmeo mais fraco pode sucumbir e morrer. Por isso, um especialista é chamado para "curar" os gêmeos, a fim de proporcionar uma vida em harmonia para ambos (Guffler, 1996). Já os Lele, do antigo Congo, acreditam que os pais de gêmeos foram especialmente homenageados por gerarem dois filhos ao mesmo tempo. Por isso, desfrutam de um elevado status social dentro das comunidades (Douglas, 1957). Atualmente no Ocidente, gêmeos são uma fonte de interesse público e celebração. Clubes, festivais, agências e instituições voltados para este público revelam a grande admiração e curiosidade por parte da população (Bacon, 2010). O maior festival de gêmeos, Twins Days Festival, ocorre na cidade de Twinsburg, em Ohio (EUA) e já está em sua $40^{a}$ edição ${ }^{4}$.

Com a finalidade de quantificar a taxa de nascimento gemelar, Smits e Monden (2009) analisaram informações de 76 países de baixa e média renda reunidas entre 1987 e 2010 e verificaram que há em média 13,1 partos duplos a cada 1000 nascimentos (\%). Estudos mostram que as maiores taxas são encontradas no continente africano (majoritariamente acima de 18\%o) e as mais baixas no continente asiático e na América Latina (majoritariamente abaixo de 9\%o), enquanto nos EUA e na Europa esta taxa é considerada intermediária (10-20\%o) (Pison \& D’addato, 2006; Reynolds, Schieve, Martin, Jeng \& Macaluso, 2003). A mesma proporção está presente em grupos étnicos que vivem nos EUA: afrodescendentes apresentam as maiores taxas de nascimento de gêmeos (13-15\%), seguido por brancos (10\%) e asiáticos (7\%o) (Pollard, 1995). No Brasil, a ocorrência média é de 9,41\%o nascimentos gemelares (Cardosodos-Santos et al., 2018).

A taxa de nascimento gemelar aumentou consideravelmente desde 1980 nos países desenvolvidos. Esse aumento parece estar ligado à maior idade das gestantes e ao maior uso de técnicas de reprodução assistida e métodos para estimular a ovulação (Pison, Monden \& Smits,

\footnotetext{
${ }^{4}$ Disponível em: https://twinsdays.org/
} 
2015). Com o aumento do status socioeconômico e a popularização das técnicas de reprodução assistida nos países em desenvolvimento, espera-se observar este mesmo padrão e, de fato, houve no Brasil um aumento de 17,34\% na taxa gemelar (Cardoso-dos-Santos et al., 2018), sendo que regiões mais desenvolvidas como Sul e Sudeste têm maiores taxas do que regiões como Norte e Nordeste (Varella et al., 2018). Na cidade de São Paulo a ocorrência média é de 11,96\% nascimentos gemelares, sendo que entre 2003 e 2014 houve um aumento de 30,82\% de partos duplos (Otta et al., 2016).

O aumento da taxa gemelar parece ser contraditório, uma vez que a gravidez múltipla apresenta grande risco para a mãe e para a prole. Algumas hipóteses foram criadas para explicar a ocorrência natural deste fenômeno em humanos. A primeira é a insurance ova hypothesis que considera o nascimento de gêmeos dizigóticos um subproduto da poliovulação. A poliovulação aumentaria a probabilidade de gravidez e diminuiria os custos de defeitos embrionários e abortos espontâneos decorrentes do avanço da idade (Anderson, 1990). Já a relaxed-screening hypothesis propõe que, com a idade, o útero materno se torna menos seletivo em relação à qualidade e quantidade da prole (Forbes, 1997), podendo resultar na formação de gêmeos DZ e MZ. Sear e colaboradores (2001) analisaram dados de 3136 nascimentos da Gambia rural, país do continente africano, que não decorreram de técnicas de reprodução assistida. Os resultados mostraram que mães de gêmeos apresentaram maior fertilidade, intervalos mais curtos entre gestações e idade mais avançada na última gestação do que mães de filhos únicos. A maior fertilidade das mães de gêmeos parece superar o alto risco de mortalidade na gestação múltipla, garantindo um maior fitness em comparação às mães de não gêmeos.

\subsubsection{Tipos de estudos com gêmeos e sua importância}

Nancy Segal (2017) diferencia duas grandes categorias de abordagens em pesquisas com gêmeos: "abordagem comparativa" e "gêmeos pelos gêmeos". A abordagem comparativa explora os fatores que influenciam a variação individual de traços físicos, psicológicos e comportamentais. O delineamento experimental clássico consiste na comparação de gêmeos MZ, que compartilham $100 \%$ dos genes que variam na população, com gêmeos DZ que compartilham, em média, 50\% dos genes. Devido a isto, as diferenças dos traços físicos, comportamentais e psicológicos em irmãos gêmeos $\mathrm{MZ}$ podem ser explicadas pelas diferenças ambientais a que os gêmeos foram submetidos, desde o período pré-natal até o resto da vida. 
Segundo esta abordagem, quanto maior a semelhança de gêmeos MZ para um determinado traço investigado, em comparação aos DZ, maior a influência genética que esse traço sofre (Knafo-Noam, Vertsbergez \& Israel, 2018; N. Segal,1990).

Além do delineamento clássico, outros nove tipos de delineamentos experimentais podem ser usados, sendo alguns deles (N. Segal, 1990):

a) estudos longitudinais: permitem observar determinados traços ao longo de períodos selecionados do desenvolvimento;

b) estudos de comparação entre irmãos gêmeos e não-gêmeos: facilita a compreensão de influências genéticas e ambientais no comportamento em questão, quando gêmeos são comparados a irmãos não-gêmeos da mesma idade. Além disso, este tipo de estudo permite observar os efeitos psicológicos e físicos que a dinâmica de uma relação gemelar acarreta;

c) gêmeos criados separados: é o delineamento mais potente para estudar influências genéticas e ambientais, uma vez que os gêmeos são separados na infância e criados em ambientes não relacionados.

Apesar do grande objetivo da pesquisa com gêmeos ser, como vimos, entender melhor a variabilidade de traços individuais na população, uma outra abordagem igualmente importante é a chamada "gêmeos pelos gêmeos". Os estudos realizados nesta perspectiva têm grupos amostrais menores e incluem análises qualitativas das relações e situações que irmãos (ãs) gêmeos (as) vivenciam em suas constelações familiares diversas (N. Segal, 2017). Além disso, parece ser fundamental estudar como fatores sociais (pais, família e instituições) afetam e são afetados pelo desenvolvimento da personalidade, pela relação e pelo comportamento dos gêmeos, e suas implicações para o bem-estar deste grupo (Bacon, 2010).

Verifica-se um aumento de centros de pesquisa e registros de gêmeos ao redor do mundo, por exemplo, em países como Estados Unidos (Gatz et al., 2015), Austrália (Murphy et al., 2019), Holanda (Ligthart et al., 2019), Nigéria (Yoon-Mi-Hur et al., 2019) e China (Huang et al., 2019) ${ }^{5}$, indicando um crescente interesse de pesquisadores de diferentes áreas por este público. A metanálise mais recente realizada com estudos de gêmeos reuniu 2748 estudos realizados entre 1958 e 2012, sendo metade destes publicados depois de 2004. A maior parte dos estudos foram realizados com gêmeos vivendo nos EUA (34\%), seguido por Reino Unido e Austrália, enquanto a Ásia (5\%), América do Sul (0,5\%) e a África $(0,2 \%)$ aparecem subrepresentadas. Nesta metanálise apenas cinco estudos coordenados por pesquisadores

\footnotetext{
${ }^{5}$ Para outros registros de gêmeos ao redor do mundo acesse o site da revista Twins Research and Human Genetics: https://www.cambridge.org/core/journals/twin-research-and-human-genetics
} 
brasileiros estão incluídos e nenhum deles é da área da psicologia, embora temas psicológicos estivessem entre os mais representados nesta metanálise (Polderman et al., 2015). No Brasil, os estudos com gêmeos e voltados à investigação de características psicológicas e comportamentais são raros. Por isso, é importante que este grupo receba mais atenção da psicologia, considerando abordagens qualitativas e quantitativas, uma vez que a gemelaridade tem muito a ser explorada e a oferecer teórica e empiricamente.

Visando suprir a lacuna brasileira e incentivar pesquisas de qualidade sobre comportamentos e processos psicológicos de gêmeos, surge o Painel USP de Gêmeos. O Painel conta com $4826^{6}$ indivíduos registrados, sendo $98 \%$ gêmeos e $2 \%$ múltiplos. A maioria dos cadastrados moram na região Sudeste $(\mathrm{N}=3568)$, seguido pelo Sul $(\mathrm{N}=725)$, Nordeste $(\mathrm{N}=$ 220), Centro-oeste $(\mathrm{N}=179)$ e Norte $(\mathrm{N}=75)$. Considerando-se o público infantil, $47,3 \%$ dos cadastrados são pais de gêmeos na faixa etária de $0-5$ anos; $17,4 \%$ são pais de gêmeos na faixa etária de 6-11; e 6,7\% são pais de gêmeos entre 12-17 anos. Já entre adultos, a faixa-etária de 18 a 30 anos representa a maior porcentagem de cadastrados $(18,2 \%)$, seguida pela faixa de 31 $40(6 \%)$ e decaindo conforme o aumento da idade (Otta et al., 2019).

O Painel tem desenvolvido estudos com gêmeos nas áreas de bem-estar, personalidade, relacionamentos familiares, desenvolvimento humano e psicometria (elaboração e validação de questionários). Dentro do contexto dos objetivos do Painel e igualmente buscando suprir a lacuna de estudos já citada, o presente trabalho usa o referencial etológico para compreender as práticas de separação ou manutenção dos gêmeos na mesma sala de aula, considerando que essas práticas são uma manifestação das crenças e práticas parentais sobre o relacionamento gemelar.

\footnotetext{
${ }^{6}$ Atualmente o número de indivíduos registrados no Painel USP de Gêmeos é de 5159
} 


\subsection{Relacionamentos familiares}

\subsubsection{Perspectiva evolucionista dos relacionamentos familiares}

A Etologia é uma área do conhecimento que nos auxilia a compreender o comportamento animal (inclusive o da nossa própria espécie) e foi a primeira disciplina a formalizar o estudo do comportamento sob a perspectiva da teoria evolucionista darwiniana (Izar, 2018). Niko Tinbergen (1963) afirmou que essa compreensão ocorre por meio das respostas à quatro questões norteadoras que permeiam o tempo e o espaço: qual a causa proximal do comportamento? (Causa imediata); como o comportamento se desenvolve ao longo do tempo? (Ontogênese); o comportamento promove a sobrevivência e o sucesso reprodutivo do animal? (Valor adaptativo); e como o comportamento se originou e foi modificado ao longo do tempo evolutivo? (Filogênese ou História evolutiva).

As duas primeiras questões referem-se ao nível proximal, ou seja, consideram o comportamento do indivíduo/população em menores unidades de tempo. A causa imediata investiga quais motivos, sejam eles fisiológicos ou externos, que levam um indivíduo a apresentar um determinado comportamento. A segunda pergunta, chamada explicação ontogenética, procura entender o desenvolvimento do comportamento ao longo da vida do indivíduo e como ele é afetado pela genética e pelo ambiente (Izar, 2018; Tinbergen, 1963).

Já as duas últimas questões referem-se à explicação distal do comportamento, considerando-o sob uma perspectiva transgeracional em unidades de tempo mais amplas (de séculos a milhões de anos). A terceira questão, chamada de valor adaptativo, objetiva entender como um determinado comportamento garante maior sobrevivência e sucesso reprodutivo para aqueles indivíduos que o apresentam. Por fim, a quarta, denominada filogênese, busca a origem do comportamento, explorando sua história evolutiva através da comparação com outras espécies (Tinbergen, 1963; Izar, 2018). No caso dos seres humanos, é importante considerar adicionalmente as causas mediais, que são os fatores sócio históricos que permeiam o comportamento (Varella et al., 2018).

As quatro perguntas podem ser complementares e ajudam a explicar melhor a origem e perpetuação dos comportamentos. A partir disso, adotamos como referencial teórico duas teorias para compreender melhor os relacionamentos familiares, especialmente a relação entre 
irmãos gêmeos. Para interpretar a causa distal utilizamos a Teoria de Seleção de Parentesco e para o nível proximal, a Teoria de Apego. Nesta seção iremos compreendê-las de forma geral para, na próxima, aplicarmos aos gêmeos.

A Teoria de Seleção de Parentesco, proposta por Hamilton em 1964, surge como alternativa distal para explicar o valor adaptativo dos comportamentos pró-sociais entre indivíduos aparentados. Esses comportamentos trouxeram um grande desafio para os pesquisadores da época, uma vez que ajudar o próximo pode implicar em um custo muito grande para o emissor do comportamento, além de parecer não trazer benefício algum para ele. Hamilton sugeriu que a probabilidade de um indivíduo se comportar de forma altruísta em relação a outro aumentava com a semelhança genética, pois ele estaria investindo na perpetuação de seus próprios genes ao facilitar a reprodução e sobrevivência de seu semelhante. Esse investimento poderia ocorrer na sobrevivência da própria prole ou na de seus familiares (Hamilton, 1964).

Pensando nisso, o sucesso reprodutivo não só é medido diretamente, quando o indivíduo reproduz e tem proles viáveis, como também indiretamente, através da reprodução e sobrevivência dos filhos de seus parentes, resultando no que é chamado de "aptidão abrangente" (Yamamoto, Alencar \& Lacerda, 2018). O modelo de Hamilton possui uma regra básica representada pela equação "rb > c", sendo " $r$ " o coeficiente de parentesco entre os indivíduos envolvidos na cooperação, "b" o benefício para o alvo e "c" o custo para o emissor do comportamento. A Tabela 1 mostra os tipos de coeficiente de parentesco. De acordo com essa regra, mesmo partilhando genes, só é vantajoso cooperar quando os benefícios em ajudar um parente próximo superam os custos dessa ajuda (Hamilton, 1964). Ainda, considerando o mesmo tipo de benefício e custo, quanto maior o coeficiente de parentesco, mais vantajoso é cooperar.

Tabela 1. Coeficientes de parentesco

\begin{tabular}{lr}
\hline Parentesco & (r) \\
\hline Filho & 0,5 \\
Irmão & 0,5 \\
Meio-irmão & 0,25 \\
Gêmeos idênticos & 1,0 \\
Primos & 0,25 \\
Netos & 0,25 \\
Cônjuge & 0,0 \\
\hline Fonte: Yamamoto, Alencar \& Lacerda, 2018, pp. 469.
\end{tabular}


Já para compreendermos as causas proximais dos vínculos familiares é fundamental discutir sobre a Teoria de Apego proposta por John Bowlby. Com o surgimento dos mamíferos há cerca de 200 milhões de anos atrás, os bebês nasceram dependentes de sua mãe para receber alimentação (Hrdy, 2011) e, por isso, acreditava-se que o forte laço que existia entre a mãe e sua prole era decorrente dessa necessidade fisiológica primária (Resende, Riparo \& Oliva, 2018). Para testar isso, Harry Harlow realizou um experimento com macacos rhesus, onde demonstrou que ao dispor protótipos de mãe de pelúcia e de arame associados à uma mamadeira de leite, os bebês rhesus preferiam à mãe de pelúcia. Caso recorressem a mãe de arame, era apenas o tempo necessário para se alimentar, antes de voltar para o conforto da mãe de pelúcia (Harlow, 1959). Inspirado nesse experimento e tendo como guia Robert Hinde, Bowlby propôs que, na verdade, o vínculo afetivo entre mãe-bebê era primário e se dava pela segurança que a cuidadora proporcionava.

O comportamento de apego pode ser entendido como um sistema que, ao ser ativado, faz com que a criança procure seu cuidador principal para obter cuidado e proteção. Ele foi decisivo evolutivamente na sobrevivência e adaptação de espécies que nascem fisicamente imaturas, com capacidade limitada de locomoção e alimentação, necessitando de cuidados para sua sobrevivência (Bowlby, 1969). Além disso, um dos principais componentes fisiológicos associados ao apego e responsável por promover e manter os vínculos afetivos é o hormônio ocitocina que, ao ser liberado, causa uma sensação de bem-estar nos indivíduos envolvidos (Campbell, 2008). Por fim, as relações de apego têm quatro características principais (Ainsworth, 1991):

a) Busca por proximidade;

b) Ansiedade de separação;

c) Base de segurança na exploração do ambiente;

d) Porto seguro em situações de perigo ou estresse.

De todas as relações existentes em mamíferos, nenhuma é mais intensa e duradoura do que a das mães primatas e seus bebês, sendo essas mães extremamente confiáveis, responsivas e possessivas (Hrdy, 2011). Por isso, o apego entre mãe e bebê é tão estudado e citado. Entretanto, ele pode ocorrer em diversas outras relações como, por exemplo, entre amigos (Fraley \& Davis, 1997), entre parceiros românticos (Sharpsteen \& Kirkpatrick, 1996) e entre irmãos (Ainsworth, 1991; Tancredy \& Fraley, 2006). 


\subsubsection{Relacionamento entre irmãos gêmeos}

Diversas pesquisas têm indicado que o relacionamento entre irmãos influencia o desenvolvimento social, o desenvolvimento cognitivo e o bem-estar psicológico dos envolvidos (Dunn, 2018). As características desta relação - se é agressiva, dependente ou empática, por exemplo - parecem ter implicações importantes para as crianças envolvidas, inclusive para a competência social, como a capacidade de gerenciar e manter relacionamentos futuros (Volling \& Blandon, 2003).

A relação entre irmãos proporciona um grau de tolerância social que cria um contexto favorável para a expressão de sentimentos positivos e negativos (Dunn, Stocker \& Plomin, 1990). Adolescentes com relações afetivas calorosas e de apoio com irmãos durante a infância relataram ter maior autoestima e maior sociabilidade com colegas quando comparados a adolescentes que tiveram pouco apoio de seus irmãos (Caya \& Liem, 1998). Crianças préescolares eram mais populares quando havia companheirismo e identificação com um irmão mais velho e aquelas que vivenciaram tanto apoio quanto um grau moderado de conflito com irmãos apresentaram maior regulação emocional e eram atentas na escola (Mendelson, Aboud \& Lanthier, 1994). Um contexto geral de relacionamento íntimo e caloroso, ainda que envolvendo conflito moderado, está associado com expressão emocional, entendimento dos sentimentos dos outros e elaboração de estratégias para resolução de conflitos (Volling \& Blandon, 2003).

A gemelaridade constitui um tipo singular de relacionamento entre irmãos. No caso de irmãos gêmeos, a codependência e a proximidade são as características mais destacadas e as pessoas, em geral, esperam que gêmeos tenham sempre uma conexão estreita e especial. Este aspecto é bastante proeminente, porque os gêmeos têm a mesma idade, vivem no mesmo ambiente e, no caso dos MZ, por compartilharem 100\% dos genes, são mais propensos a apresentar características físicas e psicológicas semelhantes (Tancredy \& Fraley, 2006).

Estudos realizados com irmãos gêmeos na pré-escola mostraram que eles gostam e procuram mais proximidade com seus irmãos, quando comparados a irmãos não gêmeos. Além disso, gêmeos que preferem permanecer próximos ficam menos apreensivos e mais confortáveis no contexto social. Portanto, essa relação parece fornece uma base de segurança para ambos (N. Segal, 1999). Se separados, apresentam indicadores de ansiedade e angústia e, caso ocorra a morte de um deles a experiência é mais intensa do que a perda de qualquer outro parente, incluindo os pais, sendo essa perda mais severa para gêmeos monozigóticos (N. Segal, 
et al., 2001; Woodward, 1988). Todas essas características - busca por proximidade, base de segurança na exploração do ambiente e ansiedade de separação - tornam evidente o apego entre irmãos gêmeos. O apego ajuda a compreender e investigar o forte vínculo característico deste grupo.

A explicação distal para este forte laço e proximidade seria decorrente da Teoria de Seleção de Parentesco (Hamilton, 1964), especialmente para MZ que, ao serem mais pró-sociais com seus irmãos, estariam beneficiando a sobrevivência e perpetuação de seus próprios genes devido ao alto coeficiente de parentesco que possuem $(\mathrm{r}=1)$, portanto "geneticamente falando, ajudar um gêmeo idêntico é como ajudar a si mesmo" (N. Segal, 1999, p. 101). Nessa direção, um estudo foi realizado para comparar o comportamento pró-social entre MZ e DZ através da realização da seguinte tarefa: eles eram incentivados a terminar um quebra-cabeças juntos o mais rápido possível, enquanto eram filmados. Posteriormente, a frequência e duração dos comportamentos cooperativos e competitivos foram mensuradas. O resultado desse estudo foi de que MZ eram mais cooperativos entre si do que DZ e resolveram mais rapidamente o problema, o que vai ao encontro com a Teoria de Seleção de Parentesco (N. Segal, 1984). Recentemente, um estudo encontrou que a relação gemelar pode ter um efeito positivo na longevidade dos gêmeos e também na longevidade do casamento (Sharrow \& Anderson, 2016).

Entretanto, a relação gemelar não pode ser simplificada e generalizada como sendo de dependência e proximidade extrema, já que tais relacionamentos variam e apresentam dinâmicas diferentes, desde proximidade excessiva à competição e conflito frequentes (Ainslie, 1997). Para Hay e Preedy (2006), três tipos principais de relacionamento entre gêmeos podem ser diferenciados. Os "gêmeos com dependência madura" mantêm uma relação próxima e funcionam bem como unidade e como indivíduos, não competem e compreendem os gostos semelhantes que possuem. Os "gêmeos em oposição" têm pouca proximidade e negam seu nascimento múltiplo, aparentemente como uma forma de afirmar a sua individualidade. Por fim, os "gêmeos que funcionam como uma unidade" são extremamente próximos, podem responder aos dois nomes e não reconhecem sua própria imagem no espelho. Além disso, têm pouca ou nenhuma amizade fora da relação.

Inspirado nas categorias de Hay e Preedy (2006) e em outros questionários sobre relacionamento entre irmãos (Dunn, Deater-Deckard \& Pickerin, 1999; Volling \& Blandon, 2003) pesquisadores israelenses elaboraram o Twin Relationship Questionnaire (Fortuna, Goldner \& Knafo, 2010). Os itens do questionário visavam captar comportamentos indicativos de proximidade, conflito, rivalidade e dependência a partir do relato materno. Participaram da pesquisa 272 mães de gêmeos MZ e 1009 mães de DZ, a idade média dos gêmeos foi de 37,6 
meses ( 3 anos). Em geral, as avaliações maternas em relação a proximidade foram muito altas, sendo que gêmeos MZ foram considerados como mais próximos e dependentes do que gêmeos DZ do mesmo sexo. As mães também relataram maior rivalidade para gêmeos DZ do mesmo sexo ao comparar com gêmeos do sexo oposto, o que atribuíram ao fato de pares do mesmo sexo terem necessidades mais semelhantes e, portanto, competirem pelos mesmos recursos. Além disso, a comparação feita pelos pais pode ser maior quando os filhos são do mesmo sexo, o que também contribui para uma maior competitividade. Entre os DZ, pares masculinos e pares femininos mostraram níveis similares de dependência, enquanto entre os $\mathrm{MZ}$ os pares masculinos foram descritos como mais codependentes, contrariando pesquisas anteriores (e.g. Penninkilampi-Kerola, Moilanen \& Kaprio, 2005). Os autores sugerem que o relato materno pode ter contribuído para contornar a relutância dos meninos em admitir dependência em pesquisas por auto relato, ajudando a superar preconceitos de gênero que podem enviesar as pesquisas.

Desde o nascimento os gêmeos estão envolvidos em uma relação triádica: mãe-gêmeo1, mãe-gêmeo2 e gêmeo1-gêmeo2. Dessa forma, o irmão desempenha uma parte importante no desenvolvimento psíquico do indivíduo em uma idade precoce, tanto quanto a mãe (Dorneles \& Schimdt, 2015). Assim, é importante levantar questões sobre a criação de gêmeos, considerando o desenvolvimento da individualidade, fusão e rivalidade entre os irmãos.

\subsubsection{Crenças e práticas maternas de criação em gêmeos}

A relação entre a mãe e seu filho propicia a primeira educação de um indivíduo sobre o seu mundo (Hrdy, 2011). O cuidado parental, além de garantir condições mínimas de sobrevivência e desenvolvimento à prole, ajuda a inserir os novos indivíduos ao ambiente ecológico e social específico ao qual eles pertencem (Keller, 2007). Portanto, as mães podem ser consideradas os primeiros agentes socializadores do bebê, comunicando-o formas de ser e agir valorizadas em seu ambiente cultural, auxiliando sua adaptação nesse contexto (Oliva, Vieira, Mendes \& Martins, 2017)

Para Harkness e Super (1986) a criança cresce no que é chamado de nicho de desenvolvimento, composto por três subsistemas: 1) ambiente físico e social no qual a criança vive; 2) costumes de cuidado e criação que são propostos através da cultura; e 3) crenças 
parentais ou etnoteorias (conjunto organizado de ideias que permeiam as atividades, as decisões e ações dos pais). Por isso, cada vez mais tem sido destacada a relevância de se analisar a criação levando-se em conta as crenças parentais. As crenças incluem metas de socialização dos filhos e práticas que os pais julgam importantes para atingi-las (Keller \& Kartner, 2013). Contudo, as crenças parentais nem sempre têm efeitos diretos nas práticas, ou seja, o que as pessoas pensam pode não corresponder ao que fazem (Westphal, Vieira, Vieira \& Prado, 2010).

As metas de socialização que os pais têm para seus filhos são importantes, pois se relacionar com o outro é essencial para a sobrevivência humana, tanto física quanto psicológica. Todo ser humano precisa de um senso de controle sobre sua vida, suas ações e o meio onde vive, bem como um senso de relacionamento e pertencimento a outras pessoas e grupos (Keller, 2018). Por isso, a autonomia e a interdependência são consideradas propensões humanas básicas que tangem o desenvolvimento do self.

Kağitçibași (2005, 2007), em sua Teoria da Mudança Familiar, argumenta que autonomia e interdependência não são dimensões opostas. Ela propõe duas dimensões para pensar o self: agência (variando entre autonomia, em que o indivíduo é orientado pelas próprias regras, e heteronomia, em que o indivíduo é orientado pelas regras dos outros) e distância interpessoal (variando de um eu "separado dos outros" e um eu "em conexão com outros"). Ainda, Kağitçibași $(2005,2007)$ demonstra que o self emerge em um determinado contexto e aponta para a necessidade de examinar as interfaces entre cultura e família. As variáveis de contexto, representadas pela cultura na qual a pessoa está inserida (individualismo ou coletivismo) e as condições de vida (i.e. urbanização, economia, renda), interagem com as variáveis familiares que compreendem o tipo de família, suas características psicológicas e o status socioeconômico. A partir disso, os tipos de self podem se derivar de três modelos de família (Kağitçibași, 2007):

a) Modelo familiar de independência: geralmente ocorre em famílias de classe média ocidental que realizam alto investimento nos filhos, valorizam a independência e autonomia da criança e priorizam a autoconfiança;

b) Modelo familiar de interdependência: geralmente ocorre em famílias rurais tradicionais onde a obediência é valorizada e a criança têm um papel fundamental no bem-estar de seus pais através de cuidado e proximidade e, por vezes, ajudando no sustento econômico familiar;

c) Modelo familiar envolvendo independência material e interdependência psicológica entre gerações: famílias em contextos tradicionalmente rurais, mas que passaram por um processo de desenvolvimento econômico. Neste modelo, o envolvimento dos filhos na 
subsistência familiar não é mais necessário e a obediência deixa de ser valorizada. Entretanto, a proximidade física e emocional com seus familiares ainda é priorizada.

É importante ressaltar que esses modelos são representações ideais e não descrições de famílias reais e sua principal contribuição é no sentido de entender como diferentes variáveis podem interagir com as crenças e práticas parentais (Oliva et al., 2017).

Além desses aspectos gerais que permeiam a criação de qualquer criança, no caso dos gêmeos existem algumas peculiaridades. A primeira é que estudos têm apontado para o impacto que os pais de gêmeos, especialmente mães, sofrem ao lidar simultaneamente com as necessidades de dois filhos da mesma idade, podendo ocorrer estafa e depressão materna (Andrade et al., 2014). Esse impacto inicia antes mesmo do nascimento dos gêmeos: um estudo feito com 51 gestantes mostrou que 33\% delas foram diagnosticadas com depressão maior (Benute et al., 2013). De forma geral, estima-se que 50 a $70 \%$ das mães de gêmeos desenvolvem depressão transitória, sendo a privação de sono e o isolamento dentro de casa os principais fatores associados a esta condição (Thorpe, Golding, Macgilivray \& Greenwood, 1991). A segunda corresponde ao desafio de formar relacionamentos únicos com cada criança. Algumas mães podem responder individualmente às necessidades de seus filhos, considerando as individualidades de cada um, enquanto outras respondem coletivamente por meio da tentativa de promover atenção e cuidados iguais para os dois gêmeos. Mães de filhos únicos têm mais momentos de interação ininterrupta com seus filhos do que mães de gêmeos. Além disso, mães de gêmeos falam menos com cada filho especificamente e podem deixar um dos gêmeos mais sozinho (i.e., falando, olhando ou segurando menos) (Rutter \& Redshaw, 1991), o que por vezes pode ocasionar atrasos no desenvolvimento da linguagem (Lytton, 1977).

Por isso, os pais de gêmeos podem se deparar com o seguinte dilema: Como distribuir os recursos entre os filhos de forma justa e igualitária, correspondendo às necessidades e características únicas e desenvolvendo a individualidade de cada um deles? (Klein, 2003). A forma como a cultura enxerga a relação gemelar influencia as crenças e práticas parentais e estas, por sua vez, irão impactar o desenvolvimento dos gêmeos.

A percepção dos pais é influenciada pela zigosidade dos gêmeos, tendo em vista que pais de MZ enxergam mais similaridades no aspecto físico, na personalidade e na habilidade dos gêmeos quando comparados a pais de DZ que tendem a ressaltar os contrastes. Esse comportamento é chamado de efeito de assimilação (Saudino, Cherny \& Plomin, 2000; Plomin, Chipuer \& Loehlin et al, 1990). MZ tendem a ser tratados como uma unidade e podem ter dificuldades em desenvolver identidade própria, sendo difícil sentirem que são únicos devido à semelhança em suas aparências e na maneira como os outros os tratam. Como resultado, em 
alguns casos, $\mathrm{MZ}$ podem adotar uma identidade única ou querer se diferenciar a todo custo do irmão (Noble, Bradley, Parr \& Duemer, 2017). Além disso, frequentemente os pais comparam os gêmeos, especialmente se houver diferenças de peso ao nascer, tempo de alta hospitalar ou diferenças nítidas de temperamento. Essa comparação, onde um é considerado "melhor” do que o outro, pode prejudicar a autoestima das crianças, reforçar estereótipos e influenciar a relação, contribuindo para uma maior rivalidade e competição direta (Hay \& Preedy, 2006).

A verdade é que existem mais perguntas do que respostas quando o assunto é criação de gêmeos. Na vida cotidiana, esse dilema descrito anteriormente pode refletir em algumas práticas, como por exemplo: usar a mesma roupa ou roupas diferentes, ter um momento a sós com um dos gêmeos ou não e separar ou mantê-los na mesma sala. Por isso, os diferentes tipos de relações entre gêmeos precisam ser levados em conta no contexto familiar e escolar, visando o seu bem-estar e ponderando as possibilidades e limitações de práticas como esta.

\subsection{Gêmeos na escola}

\subsubsection{Importância da escola para o desenvolvimento e bem-estar infantil}

A escola é fundamental para a socialização durante a infância, principalmente considerando que é nesse espaço que a criança passa a maior parte do tempo e aprende a se relacionar com outras pessoas diferentes de sua família. Além disso, a escola ajuda a construir valores, crenças, conceitos e molda a maneira de conhecer o mundo, contribuindo para a formação de indivíduos críticos, criativos e conscientes. Ela também interfere na qualidade de vida infantil e pode ser considerada como um elemento essencial para uma boa aprendizagem e o desenvolvimento integral da criança (Campos, 2018). Os ciclos escolares iniciais (Educação Infantil e Ensino Fundamental I) são muito importantes, pois são onde as crianças desenvolvem suas habilidades de leitura e escrita e iniciam seu crescimento escolar (Caniato et al., 2010).

A qualidade de vida infantil necessita ser refletida no meio escolar. Podemos considerar quatro domínios: bem-estar emocional (BE), relações interpessoais (RI), desenvolvimento pessoal e atividades (DPA) e bem-estar físico (BF) (Verdugo \& Sabeh, 2002). O BE está 
relacionado aos estados emocionais (afeto positivo/negativo) experienciados pela criança, à visão de futuro e à autoestima/autoconhecimento (e.g. como se vê e como valoriza a si mesma e como acredita que as pessoas a veem de modo geral). A RI compreende frequência, qualidade de afeto, interações positivas ou negativas, comunicação e aceitação da família, qualidade e satisfação com as relações de amizade em meio escolar e extraescolar, percepção e expectativa da imagem que os professores têm sobre ela, entre outros. O DPA está relacionado com o grau de desempenho, progresso, resultados e satisfação pessoal com as atividades escolares de aprendizagem e percepção que as crianças têm de suas habilidades cognitivas e oportunidades de desenvolvê-las. Por fim, o BF engloba o estado de saúde física da criança no que diz respeito a doenças, nível de nutrição e higiene. Pensar nestes outros fatores significa compreender as crianças como indivíduos biopsicossociais e não apenas como indivíduos cognitivos.

No caso dos gêmeos, uma implicação escolar que causa dúvidas e que pode afetar a qualidade de suas vidas diz respeito a separá-los ou mantê-los na mesma sala de aula. É na escola que eles podem ser separados pela primeira vez e, por terem uma relação única e diferenciada, essa escolha tem que ser realizada com cuidado. Portanto, uma decisão baseada em achismos sobre separá-los ou não em salas distintas pode prejudicar a jornada escolar, o desenvolvimento, o bem-estar e a qualidade de vida dos gêmeos. Sobre essa questão, compartilhamos a preocupação de Preedy (1999, p. 71, tradução própria) ${ }^{7}$ :

Eu estava particularmente preocupada porque [...] Muitas das pesquisas disponíveis têm um viés médico e científico focado em fertilização, gestação e nascimento, enquanto o desenvolvimento psicológico e a dimensão educacional são negligenciados. Como uma educadora, era uma preocupação particular para mim sobre como o desenvolvimento social e emocional dos múltiplos pode afetar seus respectivos progressos na escola e como os pais e profissionais podem ser informados com conteúdos que permitam as crianças múltiplas aproveitarem ao máximo suas oportunidades educacionais

\footnotetext{
${ }^{7}$ Trecho Original: I was particularly concerned that [...] much of the research available had a medical and scientific bias focusing upon fertilisation, gestation and birth while neglecting psychological development and educational provision. As an educator, it was of particular concern to me how the social and emotional development of multiples might affect their progress in school and how parents and professionals might be provided with information that would enable multiple children to make the most of their educational opportunities (Preedy, 1999, page 71).
} 


\subsubsection{Gêmeos devem estudar juntos ou separados?}

A decisão sobre a separação deve ser discutida cuidadosamente entre os representantes da escola, os responsáveis pelas crianças e, quando possível, com os próprios gêmeos (Hay \& Preedy, 2006), sendo que a relação que os gêmeos estabelecem entre si, bem como alguns estereótipos construídos popularmente, podem enviesar a decisão e comprometer o bem-estar deles. Após 1980, instituições escolares de diversos países renovaram documentos oficiais detalhando suas abordagens e seus currículos. Contudo, Preedy (1999) constatou que a questão gemelar não é sequer considerada pelas escolas, sendo que na Inglaterra menos de 1\% das escolas apresentaram políticas escolares oficiais sobre a questão.

Uma pesquisa realizada na Austrália com 1264 professores e 784 responsáveis verificou que $10 \%$ dos professores relataram ser conduta oficial das escolas em que trabalhavam separar todos os gêmeos, sem exceção. Eles reportaram que 29,3\% das crianças eram separadas ao entrar na escola, sendo que essa porcentagem aumentava para 50\% no segundo ano e estabilizava em $60 \%$ durante os quatro anos seguintes (Gleeson, Hay, Johnston \& Theobald, 1990). Essa pesquisa também descobriu que $25 \%$ dos pais relataram que não foram consultados pela escola quanto a decisão e um adicional de $40 \%$ dos pais se sentiram inadequadamente consultados, revelando a falta de interação e parceria entre escola e pais.

Outro estudo realizado na Inglaterra, recolheu dados de 3000 escolas e mostrou que $20 \%$ delas tinham uma abordagem flexível quanto a separar os gêmeos, $8 \%$ sempre separavam e $21 \%$ sempre os mantinham juntos, as demais não souberam reportar o tipo de abordagem. Os principais motivos relatados para a separação eram desenvolver independência e diminuir a dominância de um gêmeo em relação ao outro. Por sua vez, os motivos para mantê-los juntos eram o suporte que a relação gemelar fornecia e, principalmente, o pedido dos responsáveis (Preedy, 1999). Até onde temos conhecimento, não há nenhum estudo que tenha verificado as políticas ou condutas das escolas brasileiras frente a separar ou não os gêmeos em salas de aula distintas.

Analisando o ponto de vista das mães, um estudo com a população americana realizado por Nancy Segal e Russell em 1992, aplicou um questionário a 63 mães de gêmeos para verificar a satisfação perante políticas escolares e as razões para apoiarem ou rejeitarem a separação de gêmeos em salas de aula. Desta amostra, 84\% dos gêmeos estudavam em classes diferentes e $57 \%$ das mães eram a favor da separação nos primeiros anos escolares, e o motivo mais citado 
para tal ação é que a separação contribui para a individualidade e independência dos filhos. $\mathrm{O}$ trabalho apontou que mães de gêmeos $\mathrm{MZ}$ eram mais a favor de mantê-los juntos quando comparadas a mães de DZ.

Gordon (2014) comparou as opiniões de 131 diretores, 54 professores de jardim de infância, 201 responsáveis de gêmeos e 112 gêmeos americanos sobre a separação escolar ao entrar no jardim de infância. Ele encontrou que a maioria dos diretores (71\%) favoreciam a separação, os ideais do individualismo e, destes, 27\% admitiam separá-los mesmo contra a vontade dos pais. Entre os professores, $90 \%$ relatou não se importar de lecionar com os gêmeos na mesma sala, mas $49 \%$ eram a favor da separação. Nesta pesquisa chama atenção que $62 \%$ dos pais favoreciam mantê-los estudando na mesma sala, isso porque os pais não acreditavam que a separação beneficiasse seus filhos, nem que trouxesse sucesso acadêmico ou na aprendizagem. Além disso os pais achavam que a fase do jardim de infância era muito cedo para a separação. Quanto aos gêmeos de 3 a 5 anos, $81 \%$ gostaria de estudar na mesma sala, sendo a afiliação emocional e a falta que sentiriam um do outro os motivos mais citados. Embora a maioria dos gêmeos tenham solicitado a colocação conjunta, 19\% relatou querer ser separado devido ao comportamento dominante do(a) irmão(ã) e para ter a oportunidade de fazer amizade com outras crianças. Com o aumento da idade, os gêmeos foram um pouco mais propensos a favorecer a separação.

Com o interesse de explorar a percepção dos gêmeos quanto a separação escolar, um estudo qualitativo com 20 pares de gêmeos brasileiros entre 18 a 30 anos foi realizado. Tanto os gêmeos que estudaram juntos quanto aqueles que estudaram separados apontaram aspectos positivos e negativos de cada uma destas práticas. Contudo, grande parte das duplas apontaram que estudar junto traz mais experiências positivas do que negativas. Destacou-se a importância de serem realizados estudos que explorem diferenças de relação e personalidade entre gêmeos e que explorem também por quem a decisão foi tomada. Além disso, este estudo não verificou as perspectivas de responsáveis e educadores sobre o tema (Rodrigues, 2014).

\subsubsection{Consequências da separação escolar}

De forma geral, acredita-se que colocar os gêmeos em salas de aulas distintas seria interessante para estimular a individualidade e independência (Gleeson et al., 1990; Koch, 1966), ao passo que mantê-los na mesma sala de aula evitaria a angústia da separação e 
possíveis problemas emocionais (N. Segal \& Russell, 1992). Entretanto, não há conclusão científica se, de fato, a separação é necessariamente melhor ou pior do ponto de vista do desenvolvimento, bem-estar e comportamento (Hay \& Preedy, 2006).

As consequências da separação escolar de gêmeos começaram a ser estudadas pela primeira vez por Helen Koch em 1966. A sua pesquisa encontrou que gêmeos separados tinham maior QI e linguagem mais desenvolvida quando comparados aos que não foram separados. Entretanto diversas limitações metodológicas foram encontradas, dificultando a interpretação dos resultados (Tully et al., 2004).

Um estudo longitudinal realizado no Reino Unido analisou o comportamento na escola e o progresso de leitura de 878 pares de gêmeos em dois momentos: quando tinham cinco anos e após 18 meses. Três grupos foram avaliados: 1) crianças separadas em salas diferentes em ambas as idades; 2) crianças mantidas na mesma sala em ambas as idades; e 3) crianças que estudavam juntas aos cinco anos e foram separadas posteriormente. Este estudo mostrou que gêmeos que foram separados logo quando ingressaram na escola (5 anos), independente da zigosidade, apresentaram mais problemas internalizantes (isolamento, ansiedade e depressão) quando comparados aos que não foram separados. Em MZ esses problemas ainda persistiam na segunda análise. Os MZ separados posteriormente (terceiro grupo) pontuaram menos em habilidades de leitura quando comparados aos que foram mantidos juntos (Tully et al., 2004).

Ainda sobre este estudo, considerando-se apenas DZ, aqueles que foram separados aos cinco anos foram descritos como mais empenhados na escola quando comparados aos gêmeos DZ não separados. Não houve diferenças entre os grupos em relação a problemas externalizantes (agressividade e dificuldade em seguir regras), Transtorno do Déficit de Atenção com Hiperatividade e comportamentos sociais. Importante ressaltar que todos os achados deste estudo tiveram um tamanho de efeito pequeno. Os autores sugerem que muitos gêmeos podem se beneficiar de permanecer na mesma classe, pelo menos nos primeiros anos escolares. A separação escolar pode ser um evento estressante para eles e embora seja considerado normal e apropriado para o desenvolvimento vivenciarem um curto período de ansiedade, os resultados sugerem que essa ansiedade inicial não é temporária, pelo menos para os MZ (Tully et al., 2004).

Pesquisadores holandeses decidiram replicar o estudo de Tully e colaboradores (2004) em seu país, através do Netherlands Twin Register. Neste estudo foram incluídas avaliações comportamentais aplicadas para responsáveis de gêmeos, uma vez que no estudo inglês as avaliações foram respondidas apenas por professores. O objetivo era avaliar efeitos de curto prazo (efeitos comportamentais aos sete anos de gêmeos que foram separados aos 5 anos) e 
efeitos de longo prazo (efeitos comportamentais aos 12 anos de gêmeos que foram separados aos 5 anos), controlando diferenças comportamentais já existentes antes da entrada na escola. Para isso, os responsáveis responderam o Child Behavior Checklist quando os gêmeos completaram 3, 7 e 12 anos de idade e os professores responderam o Teacher Report Form quando os gêmeos tinham 7, 10 e 12 anos. Desta forma, pôde-se verificar se havia algum problema comportamental anterior à separação escolar (van Leeuwen et al., 2005).

Os resultados do estudo realizado na Holanda indicaram que grande parte dos gêmeos que foram separados com 5 anos já tinham problemas externalizantes aos 3 anos e tais problemas continuaram presentes posteriormente. Assim como na população inglesa, os gêmeos separados aos 5 anos apresentaram mais problemas internalizantes aos sete anos, independente da zigosidade, mas este efeito não continuou aos doze. Devido ao fato deste estudo também ter apresentado um tamanho de efeito pequeno e pelos problemas internalizantes estarem presentes por um curto período de tempo, os autores argumentam que a decisão sobre separar ou não deve ser feita com base no que os pais pensam ser melhor para si e para os gêmeos (van Leeuwen et al., 2005).

Tais resultados nos levam a indagar sobre as consequências que a separação escolar pode acarretar para os gêmeos e verificar como isso se manifesta na cultura brasileira. É necessário que pesquisadores, educadores, responsáveis e os próprios gêmeos trabalhem em equipe para tomar decisões melhor embasadas frente ao tema, além de monitorar seu progresso na escola e intervir se problemas forem identificados. Também é essencial que pesquisas continuem a investigar as causas e efeitos da separação de gêmeos na escola, bem como examinar estratégias para ajudar ajuda-los a se separar de forma mais saudável, se necessário (Tully et al., 2004).

\section{$2.4 \quad$ Justificativa}

A maioria dos estudos com gêmeos são feitos a fim de compreender melhor as influências genéticas e ambientais de uma determinada característica. A parentalidade, desenvolvimento e singularidades dos gêmeos são menos estudados e têm muito a serem explorados, especialmente considerando o aumento da taxa de nascimento deste grupo ao redor do mundo. Vários mitos e estereótipos sobre gemelaridade são perpetuados e utilizados no cotidiano podendo prejudicar a saúde, educação e o bem-estar desse grupo. 
Uma das principais práticas que sofre influência desses mitos e estereótipos é a separação ou não de gêmeos em salas distintas. Pais, psicólogos e educadores precisam refletir e se preocupar com diversas questões na educação de gêmeos que não estão presentes na educação de singulares. Há necessidade de pesquisas científicas para que as decisões sejam melhores embasadas. Pesquisadores dos Estados Unidos, Austrália e Europa (Inglaterra, Holanda e França) abordaram esse tema seja sob a perspectiva dos educadores, dos pais ou dos próprios gêmeos. Estes resultados são inspiradores para nós, contudo precisamos realizar pesquisas que se apliquem ao contexto escolar brasileiro, ao invés de apenas importar conhecimento produzido em um contexto distinto.

Considerando que 1) a relação entre irmãos gêmeos é uma relação diferenciada; 2) é nos anos iniciais escolares que os gêmeos podem ser separados pela primeira vez; 3) a importância das percepções, crenças e práticas maternas na criação de gêmeos; 4) existe uma lacuna temporal e geográfica nas pesquisas sobre o tema; e 5) a etologia pode trazer contribuições únicas para o entendimento da criação e comportamento gemelar, o principal objetivo que norteou todos os estudos foi verificar as causas e consequências da decisão de separar ou não os gêmeos em salas de aula distintas, sob a perspectiva materna. 


\section{ESTUDO 1 - Crenças e práticas maternas sobre gêmeos na escola}

\subsection{Introdução}

Os cuidados parentais cumprem duas funções importantes. A primeira é a de garantir condições mínimas de sobrevivência à prole, através de alimentação e proteção, e a segunda é a de inserir os indivíduos ao ambiente ecológico e social específico (Keller, 2007), comunicando a eles formas de ser e agir valorizadas no contexto em que vivem (Oliva et al., 2017). As crenças parentais modulam a criação parental, pois permeiam as atividades, decisões e, por vezes, ações dos pais (Harkness \& Super, 1986).

As crenças traduzem valores culturais mais amplos e sofrem influência do contexto em que as famílias estão inseridas (Kağitçibași, 2007). Através de estudos transculturais, foram identificados três tipos de orientações gerais que compõem as crenças e valores: 1) self autônomo: percepção do indivíduo como separado e autônomo e estabelecimento de estratégias de socialização focadas em qualidades pessoais; 2) self interdependente: percepção do indivíduo estando inter-relacionado com outros a sua volta, valorização da heteronomia e adoção de estratégias de socialização que valorizam a harmonia e proximidade da família; e 3) self autônomo-relacional: valorização da autonomia e auto realização, aliada a relações estreitas com a família e grupo social (Keller, 2007). Tais orientações são moldadas por variáveis como tipo de cultura, status socioeconômicos, tamanho da cidade, entre outros. Estudos têm mostrado que o tamanho populacional é um possível indicador de grau de urbanização. Cidades com altas taxas populacionais apresentam características típicas de sociedades complexas pós-industriais, onde a autonomia e a competição são mais valorizadas (Triandis, 1989; Seidl-de-Moura et al., 2008). Além disso, quanto maior a escolaridade e a renda da familia, maior a probabilidade de se valorizar essas mesmas características (Keller, 2007).

Somado aos fatores citados acima, a criação de gêmeos apresenta peculiaridades únicas em comparação a criação de filhos únicos. Os gêmeos compartilham a idade e as mesmas necessidades de desenvolvimento e os pais têm que dividir seus recursos e atenção entre duas crianças (Noble et al., 2017). Além disso, o relacionamento gemelar pode provocar preocupações sobre o desenvolvimento da individualidade, dependência e dominância extrema 
entre os filhos (Klein, 2003). Essas preocupações levantam ainda questões educacionais, como por exemplo, se os gêmeos deveriam estudar juntos ou em salas distintas, que geralmente é abordado de duas formas.

A primeira abordagem é realizada por um nível organizacional, no qual os educadores decidem uma prática geral que é aplicada para todos os gêmeos, independente das necessidades, personalidades, reações e desejos de cada par (Staton, Thorpe, Thompson \& Danby, 2012). Logo, nesses casos, a parceria da escola com os pais de gêmeos é mínima. Um estudo australiano mostrou que as mães raramente $(40 \%)$ ou nunca $(35 \%)$ eram consultadas (Gleeson et al., 1990) e, na Inglaterra, $75 \%$ das escolas primárias reportaram nunca consultar os pais ao decidir manter os gêmeos separados (Preedy, 1999).

A segunda maneira é realizada considerando-se a dimensão individual, em que as peculiaridades são levadas em conta e a decisão é realizada de forma personalizada para cada dupla (Staton et al., 2012). Esta última abordagem vem sendo considerada a mais coerente pelos estudos nos últimos anos, onde o envolvimento dos pais é mais valorizado (Beauchamp \& Brooks, 2003; Hay \& Preedy, 2006).

Ainda, algumas características como zigosidade e idade da dupla podem influenciar a decisão de separação. Um estudo mostrou que MZ são menos separados do que DZ, provavelmente porquê a proximidade mais intensa entre $\mathrm{MZ}$ causa hesitação nos responsáveis em realizar a separação e faz com que os próprios gêmeos não queiram se separar (N. Segal \& Russell, 1992). Além disso, as mães preferem que, nos anos escolares iniciais, os gêmeos estudem juntos para fornecerem apoio e segurança ao irmão nesse novo ambiente (Gordon, 2014; Grime, 2008).

Nessa direção, considerando que a mãe geralmente é a pessoa que mais conhece o relacionamento e as particularidades dos filhos, é fundamental conhecer sua percepção acerca do assunto (Staton et al., 2012). Assumindo que a decisão sobre a separação escolar, quando protagonizada pela figura materna, é reflexo de suas crenças e práticas, fatores como cultura, status socioeconômico e as características da dupla se tornam importantes objetos de estudo, pois podem interferir na probabilidade de separar ou não os gêmeos. 


\subsection{Objetivos e Hipóteses}

Os objetivos foram:

a) caracterizar a situação escolar dos gêmeos (se estudam juntos ou separados), as práticas escolares de separação e os autores desta decisão;

b) verificar quais fatores as mães acreditam ser importantes para a tomada de decisão;

c) relacionar características sociodemográficas das mães, a zigosidade, o sexo e a idade da dupla com a prática de separação;

As Hipóteses foram:

a) gêmeos brasileiros serão menos separados em salas distintas quando comparados a taxas de países como os EUA;

b) mães que moram em cidades grandes separarão mais seus filhos;

c) mães que têm maior renda e escolaridade separarão mais seus filhos;

d) $\mathrm{MZ}$, por serem mais próximos e dependentes, estudarão mais juntos quando comparados a DZ;

e) quanto maior o ano escolar em que os gêmeos se encontrarem, maior a frequência de separação.

\subsection{Material e Métodos}

\subsubsection{Participantes}

Ao todo foram obtidas 380 respostas. O primeiro passo foi selecionar os dados de acordo com os critérios de inclusão a seguir: a) a participante deveria ser mãe de gêmeos; b) residir no Brasil; e c) os filhos deveriam estudar em creche, na pré-escola ou no Ensino Fundamental I. Foram excluídas sete respostas de mães de trigêmeos, 10 de mães que residiam fora do Brasil, 63 que não atenderam ao critério de idade escolar e 13 respostas de pais. No total, a amostra foi composta por 287 mães 
Dessas 287 mães, a maioria residia na região Sudeste do Brasil. A idade média das mães foi de 37,11 anos ( $\mathrm{DP}=5,69$; mín. = 22; máx. = 50). O perfil sociodemográfico está detalhado na Tabela 2.

Tabela 2. Dados sociodemográficos das respondentes do Estudo 1

\begin{tabular}{|c|c|c|c|}
\hline Variável & Categoria & $\mathbf{N}$ & $\%$ \\
\hline \multirow{4}{*}{$\begin{array}{l}\text { Nível de } \\
\text { Educação } \\
(\mathbf{N}=287)\end{array}$} & Ensino Fundamental Completo & 10 & 3,5 \\
\hline & Ensino Médio Completo & 84 & 29,3 \\
\hline & Ensino Superior Completo & 73 & 25,4 \\
\hline & Pós-graduação & 120 & 41,8 \\
\hline \multirow{7}{*}{$\begin{array}{l}\text { Renda* } \\
(\mathbf{N}=\mathbf{2 8 7})\end{array}$} & Até 1 salário mínimo & 12 & 4,2 \\
\hline & $1-3$ & 58 & 20,2 \\
\hline & $3-6$ & 66 & 23,0 \\
\hline & $6-9$ & 48 & 16,7 \\
\hline & $9-12$ & 33 & 11,5 \\
\hline & +13 & 50 & 17,4 \\
\hline & Não responderam & 20 & 7,0 \\
\hline \multirow{5}{*}{$\begin{array}{l}\text { Região } \\
(\mathbf{N}=\mathbf{2 8 7})\end{array}$} & Sudeste & 201 & 70,0 \\
\hline & Sul & 63 & 22,0 \\
\hline & Centro-Oeste & 12 & 4,2 \\
\hline & Nordeste & 9 & 3,1 \\
\hline & Norte & 2 & 0,7 \\
\hline
\end{tabular}

A idade média das 287 duplas de gêmeos foi de 5,67 anos $(\mathrm{DP}=2,11$; mín = 1; máx = 11), totalizando 574 gêmeos, sendo que $\mathrm{N}=60$ pares estudavam em creche, $\mathrm{N}=123$ na préescola e N = 104 no Fundamental I. Quanto ao tipo de escola, 155 pares estudavam em escolas particulares e 132 estudavam em escolas públicas. As informações de zigosidade e sexo estão descritas na Tabela 3. 
Tabela 3. Características dos pares de gêmeos do Estudo 1

\begin{tabular}{|c|c|c|c|}
\hline Variável & Categoria & $\mathbf{N}$ & $\%$ \\
\hline \multirow{3}{*}{$\begin{array}{l}\text { Zigosidade relatada } \\
\text { pelas mães } \\
(\mathbf{N}=287)\end{array}$} & Monozigóticos & 91 & 31,7 \\
\hline & Dizigóticos & 148 & 51,6 \\
\hline & Não relatado & 48 & 16,7 \\
\hline \multirow{3}{*}{$\begin{array}{l}\text { Zigosidade } \\
\text { diagnosticada } \\
\text { pelo questionário } \\
(\mathbf{N}=\mathbf{2 8 7})\end{array}$} & Monozigóticos & 126 & 43,9 \\
\hline & Dizigóticos & 159 & 55,4 \\
\hline & Não diagnosticados & 2 & 0,7 \\
\hline \multirow{3}{*}{$\begin{array}{l}\text { Sexo das duplas } \\
(\mathbf{N}=\mathbf{2 8 7})\end{array}$} & Feminino & 110 & 38,3 \\
\hline & Masculino & 105 & 36,6 \\
\hline & Oposto & 72 & 25,1 \\
\hline
\end{tabular}

\subsubsection{Instrumentos}

Questionário de Diagnóstico de Zigosidade

Utilizamos o questionário de zigosidade de Christiansen et al. (2003), que é composto por quatro questões e é adotado pelo Registro de Gêmeos da Dinamarca há mais de 50 anos, apresentando confiabilidade acima de $90 \%$ neste país. Entretanto, ele foi criado para ser respondido pelos próprios gêmeos. Por isso, o Painel USP de Gêmeos traduziu e adaptou o questionário para ser respondido pelos responsáveis de gêmeos (Apêndice A).

Os gêmeos foram classificados como MZ quando: a) a mãe os descrevia como "a cara de um, focinho do outro"8 e relatava que pessoas próximas aos gêmeos tinham dificuldade em diferenciá-los; e b) a mãe não os achava tão parecidos, mas relatava que eles eram confundidos por professores e familiares. É importante ressaltar que, para serem classificados como MZ, os gêmeos tinham que ser de mesmo sexo e ter as mesmas cores de olhos e de cabelos.

Os pares de gêmeos foram classificados como DZ quando: a) os sexos eram diferentes; b) a mãe os descrevia como "nada parecidos" e tinham o mesmo sexo; c) a mães os descrevia como "parecidos como dois irmãos que não são gêmeos", tinham o mesmo sexo e não tinham as mesmas cores de olhos e de cabelos; e c) tinham o mesmo sexo, a mãe os descrevia como

\footnotetext{
${ }^{8}$ Usamos o ditado brasileiro como tradução do inglês "two peas in a pod", que significa "tão parecidos quanto ervilhas numa vagem
} 
“cara de um, focinho do outro", mas não eram confundidos por familiares e professores, além de não terem as mesmas cores de olhos e de cabelos.

Por fim, não foi possível identificar a zigosidade em dois casos: a) em que gêmeos eram do mesmo sexo, eram classificados por sua mãe como "a cara de um, focinho do outro", tinham as mesmas cores de olhos e de cabelos, mas não eram confundidos por professores e familiares; e b) em que gêmeos eram do mesmo sexo, eram classificados por sua mãe como "a cara de um, focinho do outro", eram confundidos, mas tinham cor de olhos e cabelos diferentes.

Para fins de comparação, utilizamos também a zigosidade relatada pelas mães de gêmeos.

\section{Questionário Gêmeos na Escola (QGE)}

É um survey elaborado para verificar quais as práticas e crenças das mães sobre o tema de gêmeos na escola, bem como as consequências dessas práticas (Apêndice B). O questionário incluía questões sociodemográficas, bem como perguntas fechadas e abertas sobre as práticas de separação (e.g. se os gêmeos estudavam juntos ou separados, quem tomou esta decisão, os motivos e se a escola em que os gêmeos estudavam adotava políticas de separação).

Para avaliar as crenças maternas, perguntamos o quanto as mães achavam que o sexo, a idade, a zigosidade e o relacionamento influenciavam na decisão de separar ou não os gêmeos. Para responder, as mães usavam uma escala Likert de 7 pontos (de 1= não tem influência nenhuma a $7=$ influencia totalmente). As mães também foram questionadas se achavam que os gêmeos, de modo geral, deveriam ser separados.

Como complemento, as mães foram questionadas quanto às consequências da decisão de separar ou não, em termos de: desempenho escolar, sociabilidade, individualidade, desenvolvimento da personalidade, bem-estar, satisfação (materna e dos próprios gêmeos) e melhora no relacionamento da dupla. Aqui, novamente, as mães responderam através da escala Likert de 7 pontos (de 1= não contribuiu nada a $7=$ contribuiu totalmente).

\subsubsection{Procedimentos}

Todas as mães que participaram da pesquisa assinaram o Termo de Consentimento Livre e Esclarecido aprovado pelo Comitê de Ética em Pesquisa com Seres Humanos ( $\mathrm{n}^{\circ}$ 2.606.770) (Anexo A). 
Para coleta de dados foi feita divulgação do QGE através das redes sociais e convite por e-mail às integrantes do Painel USP de Gêmeos.

\subsubsection{Análise de dados}

Para verificar as crenças maternas em relação a separação escolar e os fatores que as influenciavam, usamos a amostra como um todo $(\mathrm{N}=287)$ e realizamos estatísticas descritivas. Para examinar os fatores relacionados com a prática de separação, a análise foi feita apenas com a amostra de mães que decidiram a situação escolar dos gêmeos $(\mathrm{N}=188)$, ou seja, foram excluídas desta análise as mães que não foram autoras da decisão.

A independência entre as variáveis categóricas foi averiguada usando-se a tabela de referência cruzada com o teste de qui-quadrado de associação. Os resíduos ajustados padronizados ajudaram a entender as relações em tabelas maiores que 2x2. Se o valor do resíduo é igual ou superior a 2, por convenção, indica que o número de casos nessa célula é maior do que o esperado, já se for igual ou inferior a -2 indica que o número de casos nessa célula é inferior ao esperado pelo modelo. As análises estatísticas foram feitas com o software SPSS versão 24.

Por fim, realizamos uma análise textual das respostas às perguntas abertas através do programa IRAMUTEQ, versão 0,7, alpha 2. Este software possibilita que se quantifiquem dados qualitativos, trazendo um enfoque diferenciado às interpretações dos textos e complementando nossas análises estatísticas. O corpus textual foi antecipadamente preparado, sendo retirado o conteúdo não relacionado à pergunta de interesse, e os erros de digitação foram corrigidos. O recurso usado foi a nuvem de palavras que agrupa e organiza graficamente as palavras de acordo com sua frequência. Assim, palavras visualmente maiores indicam maior frequência de ocorrência (Camargo \& Justo, 2013). Realizamos a parametragem do corpus textual selecionando adjetivos, formas não reconhecidas e substantivos para compor a nuvem de palavras, a fim de trabalhar com os elementos plenos da linguagem. Além disso, para ilustrar, selecionamos algumas respostas que melhor exemplificam cada categoria destacada. 


\subsection{Resultados}

\section{Como é a situação escolar dos gêmeos no Brasil?}

A maioria $(65,2 \%)$ dos pares de gêmeos de nossa amostra estudavam juntos e 34,8\% separados. As mães participaram, majoritariamente, da decisão sobre separar ou não os gêmeos (65,5\%), mas em $24 \%$ dos casos as escolas decidiram sem consultar os pais e $10,5 \%$ das mães não puderam participar da decisão, pois só havia uma sala disponível por série. Em escolas particulares as mães participaram mais ativamente da decisão do que em escolas públicas [X² $=29,427 ; d f=1 ; \mathrm{p}<0,001]$.

Quanto à prática escolar, 60\% das mães reportaram que a escola era flexível quanto à alocação dos gêmeos na sala de aula e $26,5 \%$ disseram que a escola insistiu que eles deviam estudar separados (Figura 1). Realizamos um teste de qui-quadrado para verificar se havia associação entre o tipo de escola (pública ou particular) e a prática de separação, e não encontramos diferença entre os grupos $\left[\mathrm{X}^{2}=1,650 ; d f=1 ; \mathrm{p}=0,19\right]$.

Figura 1. Práticas escolares sobre separação de gêmeos na escola

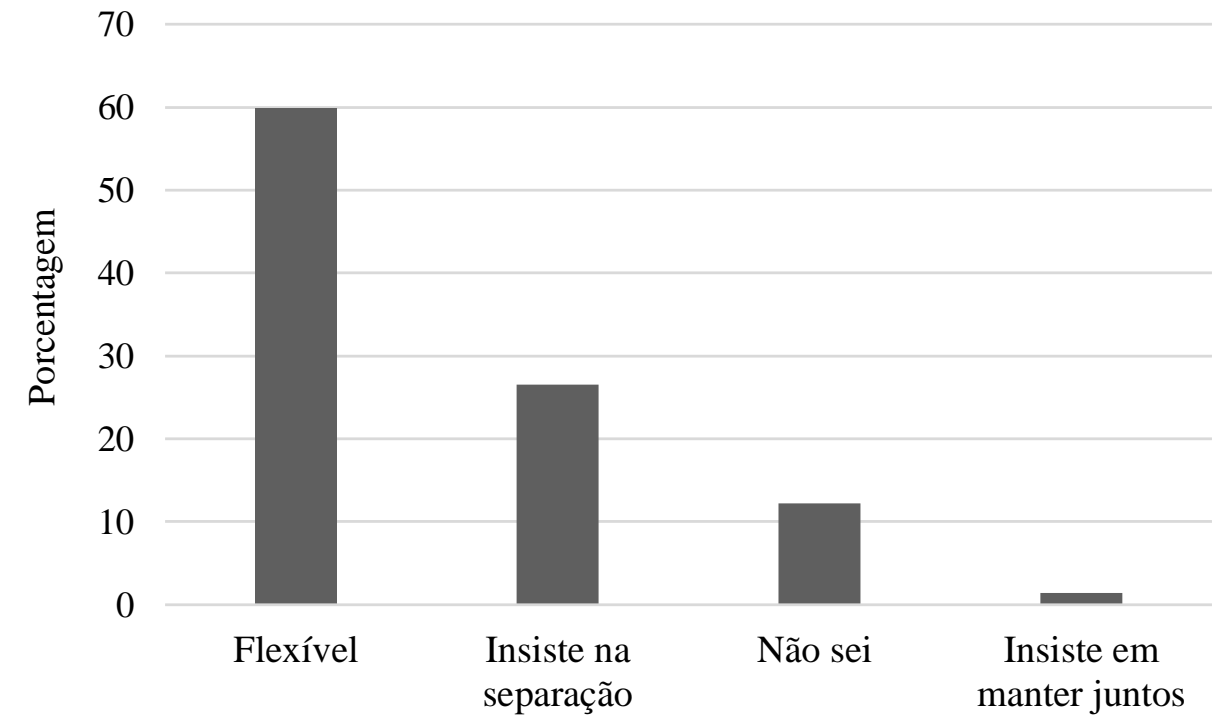

Fonte: elaboração própria. 


\section{Quais são as crenças maternas sobre a separação escolar?}

Para avaliar as crenças perante a decisão perguntamos se, de forma geral, as mães achavam que gêmeos deveriam estudar juntos ou separados. Em resposta, 33,1\% disseram que deveriam estudar juntos, 29,3\% disseram que depende da situação, 25,4\% disseram que deveriam estudar separados e 12,2\% disseram que eram indiferentes.

As mães responderam, em uma escala de sete pontos, o quanto achavam que o sexo, idade, zigosidade e relacionamento influenciavam na decisão (Tabela 4). O relacionamento foi indicado como o fator de maior influência, seguido por idade, zigosidade e sexo.

Tabela 4. Média, mediana e desvio padrão dos fatores que influenciam a decisão materna de separar ou não os gêmeos em salas distintas

\begin{tabular}{lrrrr}
\hline & Sexo & Zigosidade & Idade & Relacionamento \\
\hline Média & 2,49 & 3,51 & 4,05 & 5,23 \\
Mediana & 1,00 & 3,00 & 4,00 & 6,00 \\
Desvio padrão & 2,087 & 2,386 & 2,379 & 2,039 \\
\hline \multicolumn{2}{l}{ Fonte: Elaboração própria } & & &
\end{tabular}

Parte das mães $(\mathrm{N}=110)$ também responderam à seguinte pergunta aberta "Na sua opinião, existe algum outro fator que influencia na decisão de separar ou não os gêmeos em salas distintas?". Pode-se perceber, através da nuvem de palavras (Figura 2), que o desenvolvimento da individualidade foi o fator mais citado nas respostas, seguido pela personalidade. As mães relataram que seria melhor separar os gêmeos caso eles não tenham suas individualidades ou personalidades próprias. Muitas mães citaram que, para uma decisão bem embasada, é necessário monitoramento para verificar se estar junto com o irmão(ã) atrapalha no desenvolvimento de um dos gêmeos. 
Figura 2. Fatores que influenciam a decisão de separar ou não os gêmeos em salas distintas

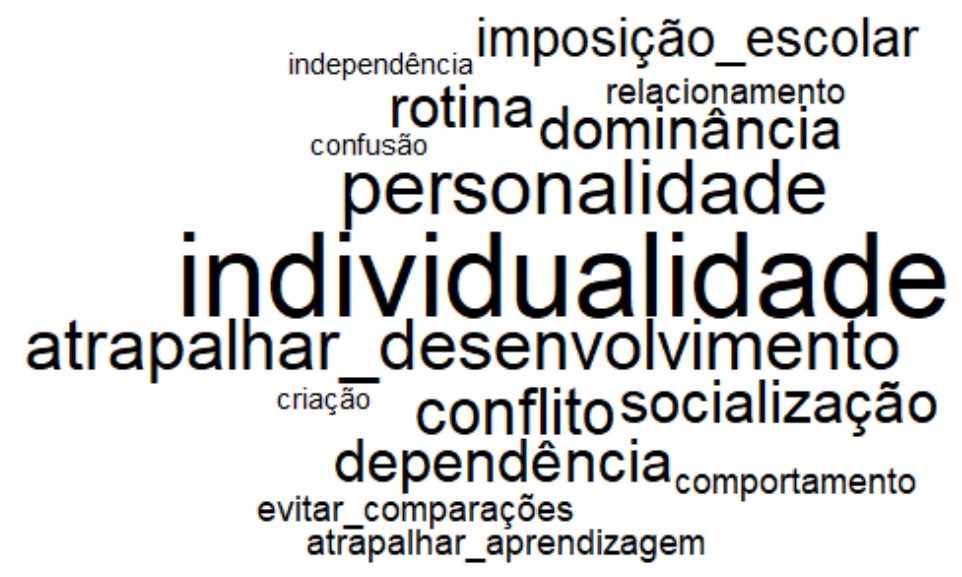

Fonte: elaboração própria

Outros fatores frequentes foram a dominância e o conflito, dimensões do relacionamento que parecem ser importantes para a decisão a favor da separação. Os trechos abaixo ilustram duas respostas que foram categorizadas neste sentido:

[..] Sabemos que há sempre o gêmeo dominante, aquele que "dita" as regras [...], e nesse caso, acho importante separar as crianças para que o gêmeo não dominante possa fazer suas escolhas sem a influência do irmão (ã) dominante (Respondente 1730).

O motivo que mais me influenciou foi por serem bem diferentes de personalidade e isso causava muitas brigas entre eles e, ao menos na escola, não tem isso, cada um se cuida.... Podem mostrar todo potencial sem o outro interferir (Respondente 1107).

Alguns fatores não se referiam ao desenvolvimento dos gêmeos em si, mas sim a questões externas como rotina familiar e imposição escolar, por exemplo.

Eles juntos ajuda bastante as mães que já estão exaustas do dia e em salas separadas o trabalho é bem mais difícil, principalmente para as mães que trabalham e são sozinhas. A correria é grande na hora de levar as crianças na escola (Respondente 1580)

Acho que a necessidade de separação é muito mais da escola do que dos gêmeos ou da família. Escuto coisas do tipo: 'para evitar comparações' e me pergunto quem irá comparar? A professora? Porque na minha realidade não é natural compará-las (Respondente 1343). 


\section{Que fatores influenciam nas práticas maternas de separação escolar?}

Para verificar que fatores estão associados com a prática de separação, realizamos o teste de qui-quadrado com a amostra de mães que participaram da decisão de separar ou manter os gêmeos na mesma sala de aula $(\mathrm{N}=188)$. As porcentagens de gêmeos mantidos juntos e separados em função da zigosidade, sexo da dupla e período escolar estão descritas na Tabela 5. Encontramos uma associação entre a faixa etária dos gêmeos e as práticas $\left[X^{2}=6,500 ; p=\right.$ $0,039 ; d f=2]$, o resíduo ajustado mostrou que gêmeos que estudavam em creches eram menos separados do que o esperado.

Tabela 5. Número de pares na mesma sala e em salas diferentes de acordo com a zigosidade, sexo e ano escolar

\begin{tabular}{|c|c|c|}
\hline & Mesma sala & Salas diferentes \\
\hline Total & $130(68,8 \%)$ & $58(31,2 \%)$ \\
\hline \multicolumn{3}{|c|}{ Zigosidade Diagnosticada $^{a}$} \\
\hline Monozigóticos & $55(69,6 \%)$ & $24(30,4 \%)$ \\
\hline Dizigóticos & $73(68,2 \%)$ & $34(31,8 \%)$ \\
\hline \multicolumn{3}{|l|}{ Zigosidade Relatada $^{b}$} \\
\hline Monozigóticos & $41(68,3 \%)$ & $19(31,7 \%)$ \\
\hline Dizigóticos & $68(69,0 \%)$ & $32(32,0 \%)$ \\
\hline \multicolumn{3}{|l|}{ Sexo da Dupla } \\
\hline Masculino & $46(63,9 \%)$ & $26(36,1 \%)$ \\
\hline Feminino & $52(72,2 \%)$ & $20(27,8 \%)$ \\
\hline Oposto & $32(72,7 \%)$ & $12(27,3 \%)$ \\
\hline \multicolumn{3}{|l|}{ Ano escolar } \\
\hline Creche & $35(85,4 \%)$ & $6(14,6 \%)$ \\
\hline Pré-escola & $49(65,9 \%)$ & $26(34,1 \%)$ \\
\hline Fundamental I & $46(63,9 \%)$ & $26(36,1 \%)$ \\
\hline
\end{tabular}

Para verificar se havia associação entre o local em que as mães residiam e a prática de separação, dividimos as cidades em três grupos segundo as características demográficas: cidades grandes (acima de 500 mil habitantes; $\mathrm{N}=89$ ); cidades médias (de 100 mil a 500 mil habitantes; $\mathrm{N}=59$ ); e cidades pequenas (abaixo de 100 mil habitantes; $\mathrm{N}=40$ ). Foi encontrada associação entre esses dois fatores $\left[\mathrm{X}^{2}=7,262 ; d f=2 ; \mathrm{p}=0,026\right]$, sendo que mães que residiam em cidades grandes separavam mais os gêmeos do que o esperado e o oposto ocorria com mães de cidades pequenas (Figura 3 ).

Também foi encontrada relação entre a renda das mães e a prática de separação $\left[X^{2}=\right.$ $15,949 ; d f=5 ; \mathrm{p}=0,007]$, mães de alta renda (acima de 13 salários mínimos) separaram mais 
os seus filhos do que o esperado. Porém, não encontramos associação com a escolaridade das mães $\left[\mathrm{X}^{2}=2,982 ; d f=2 ; \mathrm{p}>0,05\right]$.

Figura 3. Porcentagem de gêmeos que estudam juntos e separados em cidades de pequeno, médio e grande porte

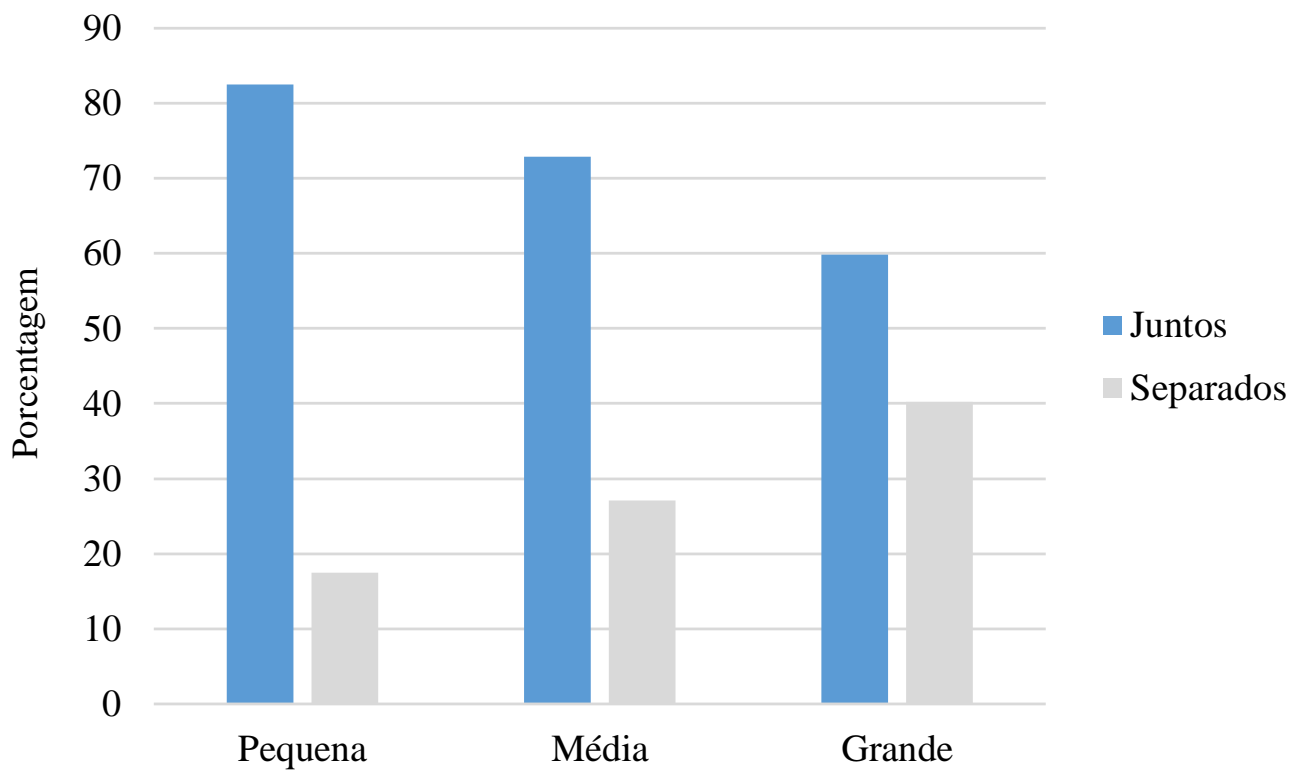

Fonte: elaboração própria

Não houve relação entre a zigosidade (diagnosticada e relatada) e a prática de separação [respectivamente, $\mathrm{X}^{2}=0,041 ; d f=1 ; \mathrm{p}=0,839$ e $\mathrm{X}^{2}=0,286 ; d f=1 ; \mathrm{p}=0,867$ ], contrariando nossa hipótese inicial. Assim como não houve relação com o sexo da dupla $\left[\mathrm{X}^{2}=1,517 ; d f=2\right.$; $\mathrm{p}=0,468]$.

\subsection{Discussão}

No presente estudo, $34,8 \%$ dos gêmeos estudavam separados, taxa semelhante a encontrada em alguns estudos holandeses (e.g. Polderman et al., 2010; Van Leeuwen et al, 2005) e australianos (e.g. Staton et al., 2012). Entretanto, esta taxa foi muito inferior a encontrada nos Estados Unidos onde a separação alcança 80 a $84 \%$ dos casos (Nilsson, Leonard, Barazanji \& Simone, 2010; N. Segal \& Russell, 1992). Os EUA têm uma cultura em que a autonomia e a individualidade são priorizadas (Kağitçibași, 1996). Os brasileiros, assim como outros povos latino-americanos, valorizam mais a conexão com a família através da 
proximidade física e psicológica em interações sociais frequentes (Carlo et al., 2007), um contexto cultural que pode explicar as menores taxas de separação gemelar no Brasil, corroborando nossa hipótese.

Em relação a atitude escolar, $60 \%$ das mães reportaram que a escola era flexível, enquanto $26,5 \%$ relataram que a escola era bem rígida quanto a sua posição em separar os gêmeos. Esta porcentagem ainda é preocupante, uma vez que as escolas deveriam considerar as peculiaridades de cada dupla ao invés de adotar regras intransigentes, seja elas favorecendo a separação ou a manutenção dos gêmeos na mesma sala (Hay \& Preedy, 2006; Tully et al., 2004; Van Leeuwen et al., 2006). Além disso, quando a atitude escolar é rígida a favor da separação, normalmente, os envolvidos estão focados nos riscos e não nas potenciais vantagens de ser gêmeos (Thorpe \& Danby, 2006). A mãe é, geralmente, a pessoa que mais conhece seus filhos e a dinâmica do relacionamento entre eles, por isso é importante que suas crenças e práticas sejam ouvidas e levadas em conta no contexto escolar.

Em nossa amostra, as mães majoritariamente participaram da decisão sobre separar ou não os gêmeos e esta participação ocorria de forma mais ativa em escolas particulares. Considerando as crenças maternas, o fator que elas acreditam ser de maior influência para a tomada de decisão foi o relacionamento dos gêmeos, seguido da idade, zigosidade e sexo. É importante ressaltar que não sabemos a direção dessa influência, por exemplo, se as mães acreditam que pares de meninas devem ser mais separadas do que de meninos ou se as mães acreditam que pares $\mathrm{MZ}$ devem estudar mais juntos do que $\mathrm{DZ}$, apenas temos uma visão geral e descritiva dos fatores que as mães acreditam que mais importam.

Uma contribuição do presente estudo em relação aos anteriores, foi a inclusão e valorização das respostas abertas das mães no survey, possibilitando uma compreensão das crenças parentais de forma qualitativa. Pode-se perceber que grande parte das respostas enfatizaram que a falta de individualidade e de personalidade própria são importantes fatores na decisão a favor da separação gemelar, sendo que estes mesmos argumentos foram apresentados em estudos anteriores (Gordon, 2014; N. Segal \& Russell, 1992). As mães também acreditam que a dominância de um(a) irmão(ã) sobre o outro e o conflito entre irmãos são fatores que justificam a separação gemelar. Um survey realizado com os próprios gêmeos descobriu que, apesar da maioria dos gêmeos de 3 a 5 anos preferirem estudar juntos, os 19\% que gostariam de estudar separados justificaram sua preferência com base na dominância do irmão (Gordon, 2014). Portanto, a dominância de um irmão em relação ao outro parece preocupar os pais e incomodar os próprios gêmeos a ponto de favorecer a separação. 
Considerando as práticas maternas, encontramos uma relação entre a idade dos gêmeos e a separação, sendo que quanto mais novos, menor a frequência de separação. Tal achado corrobora nossa hipótese e vai ao encontro de estudos anteriores (e. g. Gordon, 2014; Staton et al., 2012). Isso pode ocorrer devido aos pais acreditarem que o relacionamento gemelar proporciona suporte emocional e familiaridade e, por isso, mantê-los juntos ao entrar na escola pode auxiliar na adaptação a este novo ambiente (Staton et al., 2012). De fato, estudos têm mostrado que a separação escolar precoce dos gêmeos pode causar sentimentos como tristeza, raiva e solidão, aumentar a ansiedade de separação (Grime, 2008) e aumentar efeitos emocionais adversos (i. e. problemas externalizantes e internalizantes) (Tully et al., 2004; van Leeuwen et al., 2005). Estes efeitos podem ser ainda mais desfavoráveis para MZ em creches, uma vez que a idade de 1 a 3 anos é um período de bastante proximidade entre eles (Ferreira et al., no prelo).

Apesar da maioria dos gêmeos estudarem juntos, o Brasil é muito diferente em termos de ambientes, culturas e realidades socioeconômicas e, por isso, esperamos que as taxas de separação gemelar, decorrentes das crenças e práticas de criação parental, variem de região para região. A literatura tem encontrado que o tamanho da população das cidades onde as mães vivem influencia o tipo de parentalidade (Seidl-de-Moura et al., 2008). Cidades grandes criam um contexto de valorização da autonomia, individualidade, competição e mais isolamento (Seidl-de-Moura et al., 2008; Triandis, 1989). No presente estudo não foi diferente, pois encontramos que mães que moravam em cidades grandes separavam mais os seus filhos do que mães de cidades pequenas, provavelmente em uma tentativa para garantir maior individualidade e autonomia das crianças.

Além disso, outros estudos encontraram que famílias com maior status socioeconômico têm maior probabilidade de separar seus gêmeos ao entrarem na escola (Polderman et al., 2010; van Leuween, 2005) e nossos resultados de renda vão ao encontro desses achados. Mas, diferente do que esperávamos, não encontramos influência da escolaridade. Vale destacar a baixa variação de escolaridade em nossa amostra. De forma geral, as mães do estudo eram altamente escolarizadas, o que pode enviesar a análise.

Segal \& Russeall (1992) mostraram que pares MZ eram menos separados do que pares DZ. Não encontramos em nosso estudo relação entre a frequência de separação e a zigosidade, seja ela diagnosticada ou relatada. As proporções de separação eram bem semelhantes entre os grupos de zigosidade. Também não encontramos associação significativa entre frequência de separação e o sexo da dupla. Interessante mencionar que as mães desse estudo acreditavam que a zigosidade e o sexo são fatores de menor relevância para a decisão e, como vimos, não foram 
fatores que influenciaram nas práticas dentro de nossas análises, indicando uma possível coerência entre crenças e práticas, nesse aspecto.

O presente estudo traz uma contribuição importante para a literatura ao analisar as decisões como reflexos das crenças e práticas parentais. A partir disso, podemos ter um melhor parâmetro de como a situação escolar dos gêmeos no Brasil é tratada pelas escolas e pelas mães e uma compreensão mais profunda de quais as principais motivações e influências para as práticas de separação. 


\section{ESTUDO 2 - Relacionamento entre gêmeos e sua interface com a separação escolar}

\subsection{Introdução}

Diversas visões sobre o relacionamento entre gêmeos são baseadas em estereótipos populares e mitos que são usados para direcionar práticas de criação e práticas escolares (Beauchamp \& Brooks, 2003). A codependência e a proximidade são as características mais destacadas do relacionamento entre gêmeos e as pessoas, em geral, esperam que eles tenham sempre uma conexão estreita e especial. Entretanto, a relação gemelar não pode ser simplificada e generalizada como dependente e extremamente próxima, já que relacionamentos gemelares variam e apresentam dinâmicas diferentes, desde proximidade excessiva à competição e conflito frequentes (Ainslie, 1997).

Pesquisadores vêm tentando compreender o relacionamento entre gêmeos de diversas formas, seja através de estudos observacionais (e.g. N. Segal, 1984; N. Segal \& Hershberger, 1999), questionários e entrevistas com os próprios gêmeos (e.g. Ainslie, 1997; Tancredy \& Fraley, 2006), estudos naturalísticos com os gêmeos em casa (e.g. Lytton, 1977) e questionários e entrevistas com os seus responsáveis (e.g. H. Segal \& Knafo-Noam, 2019; Mark, Pike, Latham, \& Oliver, 2017). Nesta última abordagem, as respostas podem ser enviesadas pela perspectiva pessoal do responsável, entretanto há uma grande vantagem em acessar a percepção de quem mais convive e observa os gêmeos no cotidiano. Os questionários para pais de gêmeos podem mudar de acordo com o objetivo e embasamento teórico. Com a finalidade de avaliar comportamentos positivos e negativos é possível usar o Maternal Interview of Siblings Relationship (Mark et al., 2017). Já para entender melhor os diferentes aspectos do relacionamento entre gêmeos, o Twin Relationship Questionnaire se faz mais coerente $(\mathrm{H}$. Segal \& Knafo-Noam, 2019).

O Twin Relationship Questionnaire foi criado por pesquisadores israelenses em 2010 e, nesta versão, era composto por quatro dimensões: dependência, proximidade, rivalidade e conflito (Fortuna et al., 2010). Anos depois, a validação foi realizada e uma dimensão foi acrescentada, a dominância (H. Segal \& Knafo-Noam, 2019). O Painel USP de Gêmeos 
traduziu e validou essa escala para a população brasileira, encontrando as mesmas cinco dimensões. A partir disso, o Painel realizou um estudo para compreender de que forma a zigosidade, o sexo e a idade influenciam no relacionamento (Ferreira et al., no prelo). Participaram desse estudo 882 mães e a amostra de gêmeos tinha em média seis anos. Assim como no estudo israelense, foi encontrado que gêmeos $\mathrm{MZ}$ eram mais próximos e mais dependentes do que DZ. Através da Teoria de Seleção de Parentesco (Hamilton, 1964) é possível fornecer uma explicação distal para este resultado: $\mathrm{MZ}$, por compartilharem mais genes herdáveis, são beneficiados ao ajudarem na sobrevivência de seu irmão, pois assim auxiliam a propagação de seus próprios genes. Enquanto isso, a Teoria de Apego pode explicar a causa proximal do comportamento, uma vez que MZ têm mais semelhanças de traços psicológicos e, por isso, apresentam bastante afinidade e vínculo entre si (Fraley \& Tancredy, 2012).

O presente estudo também verificou que na faixa etária de 1 a 3 anos os gêmeos apresentavam menos proximidade (Ferreira et al., no prelo). Isso porque as habilidades interpessoais vão sendo desenvolvidas durante a infância até a adolescência, então é esperado que crianças mais velhas sejam frequentemente descritas por suas mães como mais próximas (Dumontheil, Apperly \& Blakemore, 2010). Entretanto, Ferreira et al. (no prelo) destacam que, ao considerar a zigosidade, nessa mesma faixa etária, MZ foram descritos como mais próximos do que DZ, ressaltando o quanto a proximidade nos monozigóticos se desenvolve cedo. Os resultados apontam para a importância de se considerar a influência da zigosidade e da fase do desenvolvimento nos estudos de relacionamento entre gêmeos.

Para pais e professores, o relacionamento entre gêmeos causa dúvidas quanto a práticas de criação, especialmente a respeito da separação de gêmeos, seja em casa ou na escola (Gordon, 2014; Lytton, 1977). Diversos estudos falam brevemente da importância da relação gemelar para o contexto escolar, entretanto nenhum deles relacionou os dois tópicos sistematicamente (e.g. Fortuna et al., 2010; Tully et al., 2014). Os únicos pesquisadores que se aproximaram em abordar melhor essa relação foram Hay e Preedy (2006). Eles criaram três categorias de relacionamento entre gêmeos, conforme a intensidade da proximidade e dependência entre eles ia aumentando: "gêmeos em oposição", "gêmeos com dependência madura" e "gêmeos que funcionam como uma unidade". Gêmeos com dependência madura estariam felizes e confortáveis estudando juntos ou separados. Já aqueles que funcionavam como unidade poderiam se beneficiar da separação, mas sofrer algum tipo de trauma. Por sua vez, os gêmeos em oposição poderiam odiar estudar juntos ou só aceitar estar juntos por curtos períodos de tempo. Entretanto, não houve um levantamento quantitativo da proporção de duplas 
para cada categoria e nem o desenvolvimento de uma escala sistematizada que pudesse ser aplicada para as duplas de gêmeos na prática.

De forma geral, a dominância de um gêmeo sobre o outro e o conflito entre eles são aspectos que levam as mães a optarem pela separação (Gordon, 2014; N. Segal \& Russell, 1992; Staton et al., 2012). Além disso, MZ parecem ser menos separados do que DZ, provavelmente devido a conexão intima estabelecida entre eles (N. Segal \& Russell, 1992). Portanto, o relacionamento entre gêmeos pode ter uma grande influência na decisão de separá-los ou não. Assim, é fundamental compreender melhor quais aspectos do relacionamento (dependência, proximidade, dominância, conflito ou rivalidade) estão associados com a separação escolar (Goymour, 2017) e de que modo a zigosidade e fase de desenvolvimento influenciam essa relação.

\subsection{Objetivo e Hipóteses}

Os objetivos foram:

a) investigar a associação entre zigosidade, idade e situação escolar (estudar junto ou separado) e o relacionamento entre gêmeos, baseando-se em cinco dimensões: proximidade, dependência, rivalidade, conflito e dominância;

b) caracterizar as reações dos gêmeos quanto a separação e ao reencontro.

As hipóteses foram:

a) Pares MZ serão mais dependentes e próximos do que pares DZ;

b) MZ estudarão mais juntos do que gêmeos DZ, especialmente considerando as idades mais novas;

c) Pares que apresentarem dominância e conflito serão mais separados. 


\subsection{Material e Métodos}

\subsubsection{Participantes}

Os critérios de inclusão para participar da pesquisa foram: a) responder as questões abertas do questionário de relacionamento e b) ter gêmeos na faixa-etária de 4 a 12 anos. No total, a amostra foi composta por 422 mães de gêmeos brasileiros com idade média de 36,5 anos $(\mathrm{DP}=5,84$ anos, mín. $=23$, máx. $=53)$. A tabela 6 mostra o perfil sociodemográfico da amostra.

Tabela 6. Dados sociodemográficos das respondentes do Estudo 2

\begin{tabular}{|c|c|c|c|}
\hline Variável & Categoria & $\mathbf{N}$ & $\%$ \\
\hline \multirow{5}{*}{$\begin{array}{l}\text { Nível de Educação } \\
(\mathrm{N}=\mathbf{4 2 2})\end{array}$} & Ensino Fundamental Incompleto & 3 & 0,7 \\
\hline & Ensino Fundamental Completo & 17 & 4,1 \\
\hline & Ensino Médio Completo & 137 & 32,4 \\
\hline & Ensino Superior Completo & 107 & 25,4 \\
\hline & Pós-graduação & 158 & 37,4 \\
\hline \multirow{7}{*}{$\begin{array}{l}\text { Renda* } \\
(N=422)\end{array}$} & Até 1 salário mínimo & 23 & 5,5 \\
\hline & $1-3$ & 100 & 23,7 \\
\hline & $3-6$ & 98 & 23,2 \\
\hline & $6-9$ & 65 & 15,4 \\
\hline & $9-12$ & 51 & 12,1 \\
\hline & +13 & 70 & 16,6 \\
\hline & Não responderam & 15 & 3,5 \\
\hline \multirow{7}{*}{$\begin{array}{l}\text { Região } \\
(\mathrm{N}=422)\end{array}$} & Sudeste & 286 & 67,8 \\
\hline & Sul & 97 & 23,0 \\
\hline & Centro-Oeste & 15 & 3,5 \\
\hline & Nordeste & 13 & 3,1 \\
\hline & Norte & 5 & 1,2 \\
\hline & Exterior & 4 & 0,9 \\
\hline & Não responderam & 2 & 0,5 \\
\hline
\end{tabular}

Notas: * A renda foi informada em salários mínimos. O salário mínimo de 2018 era R\$ 954,00. Fonte: Elaboração própria 
As crianças tinham idade média de 6,36 anos $(\mathrm{DP}=2,36$ anos, mín. $=4$ e máx. $=12)$. Para análise, a idade dos gêmeos foi agrupada em três faixas etárias, seguindo o ciclo escolar (ensino infantil, ensino fundamental $\mathrm{I}$ e anos iniciais do ensino fundamental II, respectivamente): 4-5 $\operatorname{anos}(\mathrm{N}=199), 6-9 \operatorname{anos}(\mathrm{N}=165)$ e $10-12 \operatorname{anos}(\mathrm{N}=58)$. Quanto a zigosidade, 44,8\% da amostra era composta de MZ, 30,3\% de DZ do mesmo sexo e 24,9\% de DZ do sexo oposto. A maioria dos gêmeos $(66,8 \%)$ estudavam juntos e 33,2\% estudavam separados.

\subsubsection{Instrumentos}

Questionário de Diagnóstico de Zigosidade

Utilizamos o questionário de zigosidade de Christiansen et al. (2003), que é composto por quatro questões e é adotado pelo Registro de Gêmeos da Dinamarca há mais de 50 anos, apresentando confiabilidade acima de $90 \%$ neste país. Entretanto, ele foi criado para ser respondido pelos próprios gêmeos. Por isso, o Painel USP de Gêmeos traduziu e adaptou o questionário para ser respondido pelos responsáveis de gêmeos (Apêndice A).

Os gêmeos foram classificados como MZ quando: a) a mãe os descrevia como "a cara de um, focinho do outro" e relatava que pessoas próximas aos gêmeos tinham dificuldade em diferenciá-los; e b) a mãe não os achava tão parecidos, mas relatava que eles eram confundidos por professores e familiares. É importante ressaltar que, para serem classificados como MZ, os gêmeos tinham que ser de mesmo sexo e ter as mesmas cores de olhos e de cabelos.

Os pares de gêmeos foram classificados como DZ quando: a) os sexos eram diferentes; b) a mãe os descrevia como "nada parecidos" e tinham o mesmo sexo; c) a mães os descrevia como "parecidos como dois irmãos que não são gêmeos", tinham o mesmo sexo e não tinham as mesmas cores de olhos e de cabelos; e c) tinham o mesmo sexo, a mãe os descrevia como "cara de um, focinho do outro", mas não eram confundidos por familiares e professores, além de não terem as mesmas cores de olhos e de cabelos.

Por fim, não foi possível identificar a zigosidade em dois casos: a) em que gêmeos eram do mesmo sexo, eram classificados por sua mãe como "a cara de um, focinho do outro", tinham as mesmas cores de olhos e de cabelos, mas não eram confundidos por professores e familiares; e b) em que gêmeos eram do mesmo sexo, eram classificados por sua mãe como "a cara de um, focinho do outro", eram confundidos, mas tinham cor de olhos e cabelos diferentes. 
Questionário de Relacionamento entre gêmeos

A versão original em inglês do Twin Relationship Questionnaire contém 22 itens desenvolvidos por Fortuna et al. (2010). O questionário foi traduzido para o português e passou pelo processo de back-translation por profissionais bilíngues (Apêndice C). Os itens foram respondidos pelas mães de acordo com a ordem de nascimento. A versão original mostrou evidência de validade para 5 fatores: dependência, proximidade, dominância, conflito e rivalidade. A tradução, adaptação e validação para a população brasileira está sendo realizada pelo Painel USP de Gêmeos.

Além disso, as mães responderam à seguinte pergunta aberta: "Em situação escolar: Quando um dos gêmeos vai para a escola e o outro não, como cada um deles reage à separação? E ao reencontro? Conte-nos qual foi o motivo da separação e indique se os seus filhos estudam juntos na mesma sala ou não”. Desta forma pudemos saber quais pares estudavam juntos e separados e a reação dos gêmeos à separação e ao reencontro sob o ponto de vista materno.

\subsubsection{Procedimentos}

Os participantes responderam a versão brasileira e online do Questionário de Relacionamento entre Gêmeos, divulgado em grupos de conversa do aplicativo Whatsapp, no site do Painel USP de Gêmeos e no site da MeTwo ${ }^{9}$. O estudo foi aprovado pelo comitê de ética do instituto de Psicologia da Universidade de São Paulo (CAAE: 79708517.8.0000.5561) (Anexo B).

\subsubsection{Análise de dados}

As estatísticas descritivas foram calculadas para as características sociodemográficas e a distribuição de MZ e DZ na amostra foi examinada. Para cada dimensão (proximidade,

\footnotetext{
${ }^{9}$ Disponível em: https://www.metwo.com.br
} 
dependência, rivalidade, conflito e dominância) foram calculados escores médios a partir das respostas das mães para cada gêmeo.

Considerando a importância da dinâmica da relação gemelar dentro de cada par (entre gêmeo 1 e gêmeo 2) e também entre os pares, utilizamos ANOVA mista para as análises. Cada dimensão foi considerada como uma variável dependente e as variáveis independentes selecionadas foram: zigosidade, faixa-etária e situação escolar (estudar juntos ou separados). O modelo foi montado da seguinte forma: 2 (par de gêmeo: gêmeo 1 e gêmeo 2) x 2 (zigosidade: MZ ou DZ) x 3 (idade: 4-6 ou 7-9 ou 10-12) x 2 (situação escolar: juntos ou separados). Para indicar a diferença entre duas médias, na comparação simples, o d de Cohen foi utilizado. O poder também foi estimado (a posteriori). As análises estatísticas foram feitas com o software SPSS versão 24.

Por fim, realizamos uma análise textual através do programa IRAMUTEQ, versão 0,7, alpha 2. O recurso usado foi a análise de similitude, que se baseia na teoria de grafos e possibilita identificar a co-ocorrência de palavras e a conexão entre elas (quanto mais espesso o nó, maior a co-ocorrência dos termos nos textos) (Camargo \& Justo, 2013). Para ilustrar, selecionamos algumas respostas que exemplificam cada categoria destacada.

\subsection{Resultados}

\section{Ordem de nascimento e relação gemelar}

Efeitos no nível intra-par foram avaliados de acordo com a ordem de nascimento (gêmeo 1 e gêmeo 2) e com a interação com a zigosidade. Foi encontrado um efeito principal para ordem de nascimento em relação a conflito $(\mathrm{F}(1,410)=3,842 ; \mathrm{p}=0,05)$ e dominância $(\mathrm{F}(1$, $410)=6,665 ; p=0,01)$. O gêmeo que nasceu por último foi apresentado pelas mães como mais conflituoso (Mgêmeo1 = 3,18; $\mathrm{SE}=0,055 ; \mathrm{CI}=[3,07$ - 3,29] e Mgêmeo2 = 3,28; $\mathrm{SE}=0,062$; 95\% CI $=[3,16-3,40])$ e menos dominante $(\mathrm{Mgêmeo1}=3,62 ; \mathrm{SE}=0,066 ; \mathrm{CI}=[3,50-3,75]$ e Mgêmeo2 = 3,31; $\mathrm{SE}=0,074 ; 95 \% \mathrm{CI}=[3,16-3,46])$. O poder observado para conflito e dominância foi de 0,49 e 0,73 , respectivamente. Não foram identificados efeitos significativos para a interação da ordem de nascimento com zigosidade e com a situação escolar.

\section{Zigosidade e Relação gemelar}


Encontrou-se efeito principal de zigosidade para dependência $(\mathrm{F}(1,410)=12,517$; $\mathrm{p}<$ 0,001 ; poder observado $=0.85$ ). Pares $\mathrm{MZ}$ foram reportados como sendo mais dependentes quando comparados a pares de $\mathrm{DZ}(\mathrm{MZ}=4,07 ; \mathrm{SE}=0,062 ; \mathrm{CI}=[3,94-4,19]$ e $\mathrm{DZ}=3,76 ; \mathrm{SE}$ $=0,058 ; 95 \% \mathrm{CI}=[3,65-3,88])$.

\section{Situação escolar e relacionamento entre gêmeos}

Encontrou-se efeito principal da situação escolar para rivalidade $(\mathrm{F}(1,410)=4,097 ; \mathrm{p}$ $=0.044$; poder observado $=0,52$ ). Pares que estudavam separados foram mais rivais do que pares que estudavam juntos $($ Juntos $=3,45 ; \mathrm{SE}=0,067 ; \mathrm{CI}=[3,32-3,58]$; separados $=3,67$; $\mathrm{SE}=0,085 ; 95 \% \mathrm{CI}=[3,50-3,84])$. Não houve interação entre situação escolar e zigosidade.

\section{Situação escolar, zigosidade, idade e relacionamento entre gêmeos}

Foi encontrado um efeito de interação para dependência $F(2,410)=3,300 ; p=0.043$; poder observado $=0,60)$ e dominância $\mathrm{F}(2,410)=3,158 ; \mathrm{p}=0.015$; poder observado $=0,74)$. Os testes a posteriori mostraram que DZ na faixa etária de 4 a 5 anos que estudam juntos são mais dependentes do que DZ que estudam separados nessa mesma idade ( $\mathrm{M}_{\text {diff }}=0,570 ; \mathrm{SE}=$ $0,176 ; d=0,001)$. Além disso, MZ na faixa etária de 6-9 anos que estudam separados são mais dominantes do que os que estudam juntos nesta mesma condição $\left(\mathrm{M}_{\text {diff }}=0,391 ; \mathrm{SE}=0,150 ; d=\right.$ 0,009) (Figura 4). 
Figura 4. Escores médios de dominância para gêmeos MZ que estudam juntos e separados de acordo com a faixa-etária

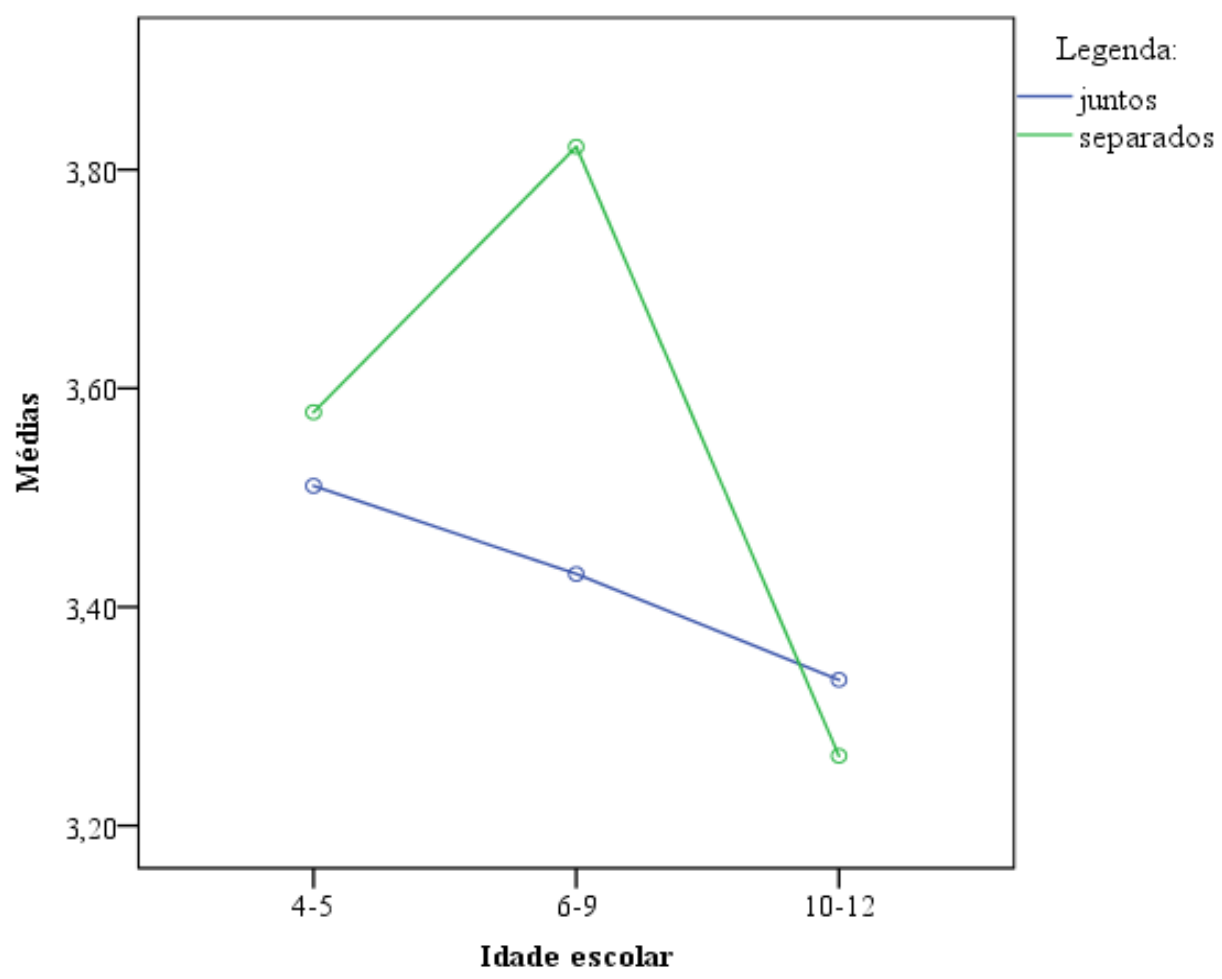

Fonte: Elaboração própria

\section{Como os gêmeos reagem à separação escolar?}

Realizamos análises de similitude para compreender as reações dos gêmeos à separação e ao reencontro $(\mathrm{N}=370)$. Para tanto, separamos dois grupos: a) percepção de mães de gêmeos que estudavam juntos $(\mathrm{N}=241)$; e b) percepção de mães de gêmeos que estudavam separados $(\mathrm{N}=129)$.

Dentre as mães de gêmeos que estudavam juntos, 25,3\% relataram que eles nunca ou raramente foram separados. Quando um dos gêmeos era impossibilitado de ir à escola (normalmente por problemas de saúde), o outro também não era levado.

Elas ficam doentes se separadas, portando se uma falta a outra não vai. Elas preferem ficar juntas (Respondente 465).

Nunca levei uma só para a escola [...] porque elas choram muito se separo, mesmo que seja uma na sala e a outra no quarto (Respondente 325).

Minhas gêmeas nunca vão à escola uma sem a outra, seja qual for o motivo [...] em hipótese alguma. Elas não se sentem seguras uma sem a outra (Respondente 508).

Considerando o restante das mães que separavam os gêmeos quando necessário (75,7\%), nossa amostra ficou dividida entre gêmeos que reagiam bem à separação e gêmeos que não 
aceitavam ou eram separados a contragosto (Figura 5). Neste último caso, reações como tristeza, saudade, preocupação e choro foram comuns.

Elas sempre reagiram muito bem à separação, mas desde sempre incentivei a individualidade delas. Durante a educação infantil estudaram separadas e nunca apresentaram sofrimento, pelo contrário amaram ter professoras e amigas diferentes. Hoje, no ensino fundamental, estudam juntas, mas sentam longe uma da outra e têm amigas diferentes, no entanto, brincam muito juntas e são confidentes [...] (Respondente 1235)

Em caso de doença quando tivemos que deixar um em casa e mandar o outro para escola ambos lidaram tranquilamente com a separação, mas no final do dia é perceptível a saudade que ambos sentem um do outro! Parece que ficaram meses separados! (Respondente 555)

Os dois acabam ficando em casa, porque não conseguem ficar separados... ficam infelizes e sofrem muito. Estão estudando na mesma sala, mantém amigos distintos, mas necessitam estar próximos, sempre, um do outro (Respondente 964).

Foram a contragosto nessas situações e por relato da prof. o que foi falava o tempo todo no irmão e o que não foi, da mesma forma, ficava narrando o que o irmão estaria fazendo na escola (Respondente 1220). 
Figura 5. Análise de similitude da reação à separação e ao reencontro de gêmeos que estudam juntos

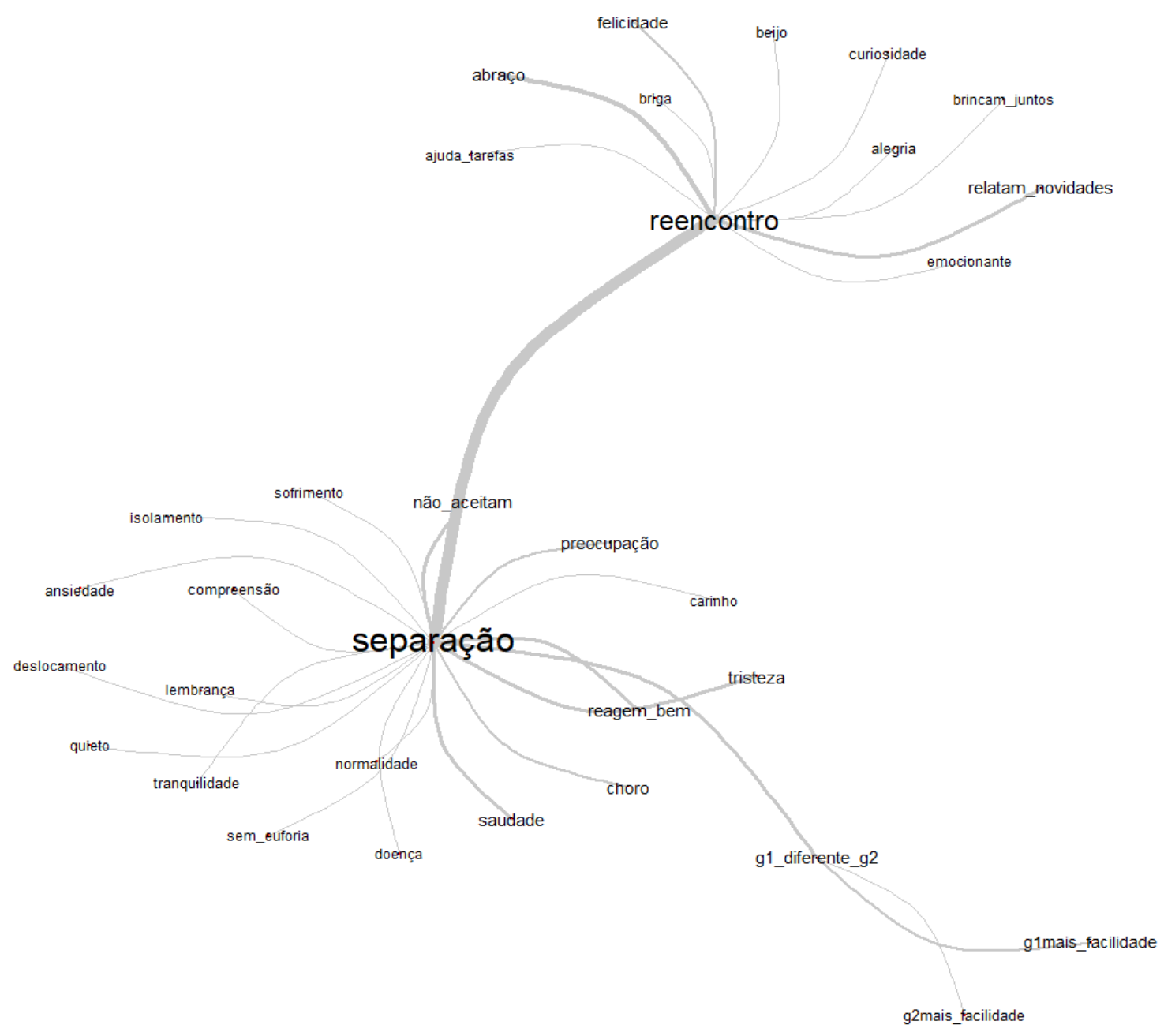

Fonte: Elaboração própria

As mães frequentemente ressaltavam a diferença de reações dentro do par de gêmeos: enquanto um dos gêmeos era caracterizado por lidar bem com a separação e até desejá-la, o outro apresentava comportamentos como tristeza, irritação e isolamento.

De forma geral, no reencontro, os gêmeos costumavam se abraçar, contar as novidades sobre o dia e se sentiam felizes.

Para o segundo grupo, a análise de similitude (Figura 6) mostrou que grande parte dos gêmeos reagiram bem à separação, apesar de reações como saudade, preocupação e tristeza ainda estarem presentes. Mesmo já estando "acostumados" com a separação, algumas mães 
relataram que os gêmeos não gostam de ir sem o irmão para a escola e, por isso, insistem para ficar em casa também. Mas, diferente do primeiro grupo, as motivações eram, de acordo com as mães, mais no sentido de ciúme/incômodo do irmão estar em casa do que por não conseguir ficar longe dele. Veja abaixo os trechos:

Elas não estudam na mesma sala desde que foram para a creche, então sempre agem de forma natural à separação e não sentem tanto quando uma ou outra não vai à escola [...] (Respondente 953).

Estudam em salas diferentes e quando uma falta a outra fica chateada. Aconteceu algumas vezes de uma ter consulta médica e a outra não, a que não foi ficou enciumada (Respondente 757).

Quando um dos gêmeos fica doente, aquele que está bem também não quer ir à escola, quer ficar em casa também, mas por ciúmes, de poder ficar com a mãe (Respondente 190). 
Figura 6. Análise de similitude da reação à separação e ao reencontro de gêmeos que estudam separados

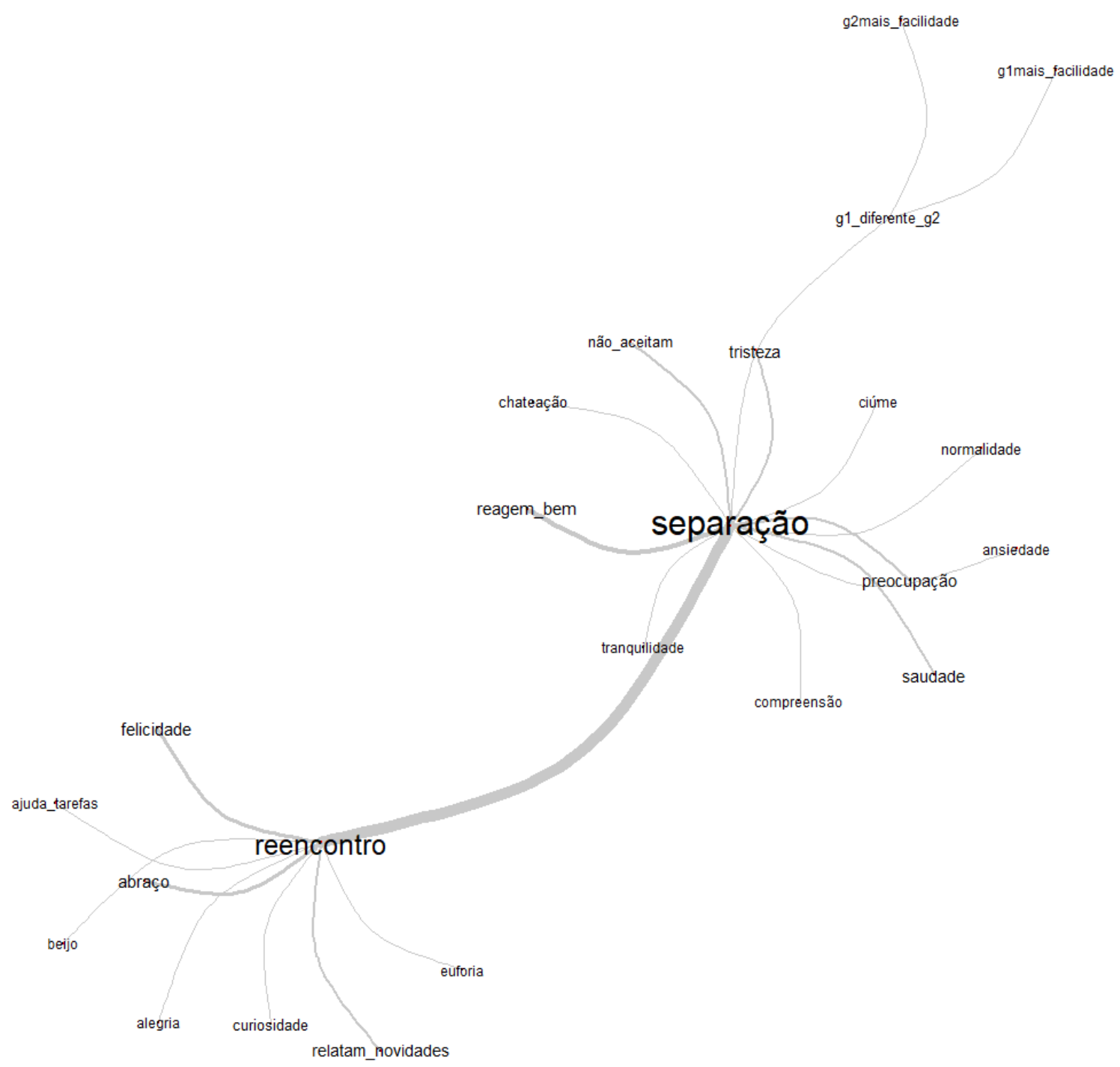

Fonte: elaboração própria

As reações ao reencontro são muito parecidas entre os dois grupos. Os gêmeos ficavam felizes, se abraçavam e relatavam as novidades do dia.

Como estão agora em salas separadas ambas ficam bem na escola por terem bastante amiguinhos, contudo o reencontro é uma euforia [...] é possível perceber o quanto sentiram falta uma da outra. Ficam sempre melancólicas e se beijam, se abraçam, a fala fica mais infantilizada... (Respondente 585).

[..] Elas trazem coisas da escola para a gêmea que não foi. Conversam com a professora da gêmea que não foi para explicar o motivo da ausência; quando 
se reencontram, vibram de felicidade.... para logo depois já discutirem por bobagem... (Respondente 710).

[...] O reencontro sempre é bem empolgante, eles gritam o nome um do outro e geralmente sorriem e se abraçam [...] (Respondente 38)

\subsection{Discussão}

No presente estudo, gêmeos MZ foram considerados por suas mães como mais dependentes do que DZ. Tal resultado está de acordo com os achados de Fortuna et al. (2010), H. Segal \& Knafo-Noam (2019) e Ferreira et al. (no prelo). O compartilhamento genético e ambiental propicia aos MZ uma maior semelhança em relação a interesses, empatia e aspectos psicológicos, o que intensifica suas interligações (Tancredy \& Fraley, 2006). Além disso, os gêmeos têm uma forte relação de apego entre si, desde a infância até a idade adulta. Um estudo conduzido pelo Painel USP de Gêmeos mostrou que MZ adultos eram tão apegados entre si quanto com suas mães, enquanto que para os DZ seu irmão era a segunda figura mais forte de apego, após a mãe (Landerbergen et al., em preparação), corroborando estudos anteriores (Fraley \& Tancredy, 2012). A explicação distal deste efeito de zigosidade para a dependência pode ser encontrada na Teoria de Seleção de Parentesco (Hamilton, 1964), mencionada anteriormente.

Ainda em relação à dependência, encontramos que durante a faixa etária de 4 a 6 anos gêmeos DZ que estudavam separados eram menos dependentes do que DZ que estudavam juntos. Uma possível explicação para esse fenômeno é o fato dessa co-dependência já ser menor nesse grupo, uma vez que apresentam menor semelhança de interesses e aspectos psicológicos. Com a separação de ambiente, as diferenças entre eles podem se intensificar e as experiências únicas podem tornar a relação ainda menos dependente. Aparentemente, a dependência de $\mathrm{MZ}$ não sofre interferência do ambiente escolar distinto, uma vez que, mesmo nessas condições, o irmão continua sendo reportado como o melhor amigo (N. Segal, 1999). Outra explicação plausível seria o receio das mães em separar as crianças nessa idade, especialmente aquelas com forte vínculo (Grime, 2008), pensando nisso, seria mais fácil para as mães separarem aqueles que já não são tão dependentes um do outro. 
Encontramos também que gêmeos que estudavam em salas distintas apresentavam maior rivalidade, independentemente da zigosidade. Neste modelo de análise não é possível saber a causalidade do resultado, ou seja, se os gêmeos já apresentavam maior rivalidade e, consequentemente, foram separados ou se por causa da separação desenvolveram maior rivalidade. Nós hipotetizamos que a rivalidade foi a causa para a separação. Isso porque, por terem a mesma idade, os gêmeos compartilham as mesmas necessidades físicas, emocionais e econômicas e, sob a perspectiva evolucionista, disputam os recursos limitados oferecidos pelos pais, especialmente na infância, onde são totalmente dependentes deles para sobreviver (Trivers, 1972). Em consequência, como uma tentativa de reduzir a rivalidade, os irmãos tendem a desenvolver papéis distintos e complementares no sistema familiar, criando assim “nichos familiares” únicos para si (H. Segal \& Knafo-Noam, 2018). Se os irmãos já apresentam maior rivalidade dentro de casa, ao começarem a estudar juntos irão compartilhar a mesma professora, os amigos e as experiências, de forma que a disputa entre eles pode se intensificar ainda mais. Logo, separar os gêmeos em salas distintas pode facilitar a construção do nicho único, tanto no ambiente escolar quanto no familiar, contribuindo para a redução da rivalidade a longo prazo.

No que tange a dominância, gêmeos MZ na faixa etária de 6 a 9 anos que estudavam separados apresentavam mais dominância do que aqueles que estudavam juntos. A dominância é uma dimensão diádica, que se manifesta nos dois gêmeos. Frequentemente um indivíduo adota o papel dominante, enquanto o outro apresenta atitudes mais submissas. Nesse estudo, ao explorar o nível intra-par, encontramos que o gêmeo mais velho normalmente é o mais dominante. Segundo o trabalho de Ebeling e colaboradores (2003), que explorou a assimetria da relação gemelar e suas consequências para o bem-estar, a dominância está mais presente em MZ. Na infância e no início da adolescência a assimetria (i. e. ser dominante ou submisso) decorre do processo de individualização e constituição do self, quando um gêmeo quer se diferenciar de seu irmão. Como os gêmeos MZ são constantemente confundidos por causa de sua semelhança física e psicológica, eles tendem a assumir papéis diferentes para facilitar o processo de individualização entre eles. Entretanto, de forma geral, o bem-estar do gêmeo submisso parece ser prejudicado pela dominância do irmão (Moilanen, 1987), apesar das consequências variarem a depender do sexo da dupla e do tipo de dominância. A dominância que parece causar prejuízos de forma mais direta, é a dominância psicológica. Esta costuma ser mais comum em pares de sexo oposto, onde o homem frequentemente é submisso e, em consequência, apresenta depressão, anedonia, baixa confiança e nervosismo (Ebeling, 2003). 
A dominância foi um fator bastante citado pelas mães do Estudo 1 a favor da separação e também foi uma motivação presente em outros trabalhos (e. g. Preedy, 1999; Staton et al., 2012). Mas por que só houve relação entre dominância e situação escolar e dominância na faixa etária de 6 a 9 anos? Nossa hipótese é que nesta faixa etária as mães já estão mais seguras para fazer a separação. Quatro anos é a idade mínima obrigatória para iniciar a jornada escolar no Brasil, sendo que com seis anos a criança faz a transição do Ensino Infantil para os anos iniciais do Ensino Fundamental (LDB, 2018). Mesmo que no Ensino Infantil um dos gêmeos já apresente dominância em relação ao outro, os pais podem ficar receosos em separar as crianças logo ao entrar na escola, pois este já é um momento difícil, envolvendo ausência dos responsáveis em um ambiente completamente desconhecido. Com a passagem para o Fundamental I, os pais podem se sentir mais seguros em realizar a separação, seja por aproveitarem a transição ou porque os gêmeos já estão mais adaptados ao ambiente escolar e com suas amizades melhor estabelecidas. Esses dados nos mostram o quanto o período do desenvolvimento pode influenciar o relacionamento entre os irmãos e também as práticas de separação.

É interessante ressaltar que, diferentemente do que esperávamos, não encontramos efeito de zigosidade em relação à proximidade. Outro estudo conduzido por nosso grupo mostrou que pares MZ na faixa-etária de 1 a 3 anos eram significativamente mais próximos do que pares DZ nesta mesma faixa etária, enquanto que nas demais idades essa diferença deixava de ser significativa (Ferreira et al., no prelo). Isso pode explicar o motivo da nossa hipótese não ser corroborada, já que as crianças deveriam ter no mínimo 4 anos para serem incluídas neste estudo.

Colocar os gêmeos em salas distintas requer cuidado e consulta aos pais, pois normalmente os gêmeos tiveram pouca ou nenhuma experiência com momentos de separação antes do início da escolarização (Hay \& Preedy, 2006), por isso realizamos uma análise qualitativa das reações à separação. Um quarto das duplas de nossa amostra, por opção materna, não haviam sido separadas em nenhuma instância e as justificativas mais comuns para tal prática eram a tristeza, desconforto e infelicidade dos gêmeos ao ficarem separados. Esses dados nos mostram as diferentes concepções sobre criação gemelar na prática e a literatura tem mostrado que enquanto algumas mães visam promover a independência e proporcionar experiências de socialização que não sejam acompanhadas do irmão, outras criam os gêmeos como unidades que não devem ser separadas (Koch, 1966; Robin, Corroyer \& Casati, 1996).

Ainda, algumas mães também relataram que os gêmeos reagiam de formas diferentes à separação. Era comum um dos gêmeos "reagir bem", enquanto o outro tinha dificuldades (i.e. 
ficar triste, isolado) ou não aceitava ser separado de seu irmão, independentemente de estudarem ou não na mesma sala. Apesar da mídia reforçar o estereótipo de que gêmeos são unidades idênticas que querem as mesmas coisas (Preedy, 1999), dados assim nos lembram que os indivíduos da dupla podem apresentar características, vontades e reações distintas e, por vezes, conflitantes e opostas. Através das análises intra-par do presente estudo pudemos verificar que a ordem de nascimento influencia o quanto um indivíduo é mais conflituoso e dominante do que o outro. A partir disso, somos indagados a pensar nos seguintes questionamentos: Como agir quando um gêmeo quer ser separado do irmão e o outro não? Quais as consequências psicológicas disso para os gêmeos?

De forma geral, sentimentos como tristeza, saudade e preocupação decorrentes da separação temporária foram frequentes, mesmo entre aqueles que estudavam em salas distintas e que, por isso, supostamente estivessem mais acostumados a estar longe do irmão. No reencontro, sentimentos positivos e demonstrações de afetos como abraços e beijos eram predominantes. Entender as reações e sentimentos ocasionados pela separação dos gêmeos e suas interfaces com a dinâmica de relacionamento das duplas é fundamental para que práticas melhor embasadas sejam realizadas, priorizando o bem-estar dos gêmeos e suas famílias. 


\section{ESTUDO 3 - Consequências da separação de gêmeos na escola sob a perspectiva materna}

\subsection{Introdução}

A escola é um ambiente importante para o desenvolvimento infantil e fundamental para a socialização neste período, principalmente considerando que é nesse espaço que a criança passa a maior parte do tempo e aprende a se relacionar com outras pessoas diferentes de sua família (Campos, 2018). Além disso, os ciclos escolares iniciais (Educação Infantil e Ensino Fundamental I) são etapas críticas, em que as crianças desenvolvem habilidades de leitura e escrita e iniciam sua jornada escolar (Caniato et al., 2010). A entrada da criança na escola é um evento que pode causar estresse e apreensão nos pais. No caso de pais de gêmeos há ainda preocupações adicionais como, por exemplo, se devem separar os gêmeos ou deixá-los na mesma sala de aula (N. Segal \& Russell, 1992). As decisões acerca da separação não tendem a ser realizadas pensando nos gêmeos como indivíduos únicos e sim centradas no relacionamento. Portanto, a questão chave é se a ausência ou presença do gêmeo no mesmo ambiente escolar seria problemática (Staton et al., 2012).

A literatura ressalta que as decisões sobre separar ou não têm que ser realizadas pelos pais, em conjunto com a escola e, quando possível, considerando a opinião dos próprios gêmeos (e.g. Hay \& Preedy, 2006; White et al., 2018). As principais motivações que levam os pais a separarem ou não os gêmeos são: desempenho escolar, desenvolvimento da individualidade e identidade, relacionamento, bem-estar dos gêmeos e sociabilidade (Gleeson et al., 1990; N. Segal \& Russell, 1992; Staton et al., 2012).

A maioria dos estudos existentes sobre o tema focam no desempenho escolar e em problemas comportamentais. Tully e colaboradores (2004) analisaram o comportamento escolar e o progresso de leitura de 878 pares de gêmeos em dois momentos: ao entrar na escola (cinco anos) e após 18 meses. Eles encontraram que os gêmeos que foram separados logo quando ingressaram na escola apresentaram mais problemas internalizantes quando comparados aos gêmeos que não foram separados e, em MZ, esses problemas persistiram após os 18 meses. Pesquisadores holandeses replicaram esse estudo e encontraram os mesmos resultados, entretanto os problemas internalizantes não persistiram a longo prazo (aos doze anos) e não diferiram em função da zigosidade. Esse estudo também verificou que grande parte 
dos gêmeos que foram separados com cinco anos já tinham problemas externalizantes aos 3 anos e tais problemas continuaram presentes posteriormente (van Leeuwen et al., 2005). É importante se atentar para o fato de que ambos os estudos relataram tamanhos de efeitos pequenos em seus resultados.

Dilalla e Mullineaux (2008) também apontaram que dificuldades emocionais e comportamentais prévias eram fatores importantes para as consequências da situação escolar dos gêmeos. Eles exploraram o comportamento de MZ que estudavam juntos e separados dos quatro aos sete anos $(\mathrm{N}=2022)$ na Inglaterra e no País de Gales. Gêmeos que foram colocados em salas de aula separadas apresentaram escores mais elevados no que diz respeito a dificuldades de conduta, problemas com colegas e problemas comportamentais gerais do que gêmeos que estudavam juntos. É possível que as crianças que foram colocadas em salas diferentes já tivessem problemas de conduta prévios, resultando nesta diferença encontrada entre os grupos.

Um estudo mais recente explorou o efeito cumulativo da situação escolar nos resultados acadêmicos (desempenho, motivação e habilidades cognitivas). A amostra foi de 9131 pares de gêmeos que moravam no Reino Unido e Canadá e os dados foram coletados quando os gêmeos tinham 7, 9, 10, 12, 14 e 16 anos de idade. Os resultados mostraram que gêmeos que estudavam juntos e separados não diferiram para nenhum dos parâmetros e não houve efeito cumulativo da separação ao longo dos anos de educação. Também não houve diferenças entre os dois países, nem entre sexo e zigosidade (White et al., 2018).

Em relação a individualidade, não há nenhuma evidência empírica que mostre que a prática de separação na escola contribui para o desenvolvimento desse aspecto (Staton et al., 2012). Para Nancy Segal (2000), a proximidade afetiva que alguns gêmeos apresentam, principalmente os MZ, não significa necessariamente perda de individualidade e autonomia. Pelo contrário, a presença do co-gêmeo parece ser um fator protetivo de saúde mental em um ambiente novo que provoca estresse, especialmente nos anos iniciais (Sandbank, 1999).

Espera-se que, devido à relação de apego entre os gêmeos, a presença do irmão facilite a exploração do novo ambiente e ajude o indivíduo a ser mais confiante no círculo social, facilitando a sociabilidade (Caya \& Liem, 1998). Por outro lado, aqueles que são separados de seu gêmeo podem sofrer estresse emocional e ter menos confiança para explorar o ambiente ao seu redor (N. Segal \& Russell, 1992). Ao testar isso, Goymour (2017) não encontrou nenhuma diferença nos níveis de competência social entre aqueles que estudavam juntos e separados, o autor ressalta que é preciso cautela na interpretação do resultado, uma vez que a pesquisa têm um tamanho amostral bastante reduzido. 
É necessário compreender as crianças como indivíduos biopsicossociais e não apenas focar na dimensão cognitiva do desenvolvimento. O bem-estar emocional e as relações interpessoais que as crianças estabelecem são de extrema importância para a qualidade de vida infantil (Verdugo \& Sabeh, 2002) e precisam ser levadas em conta no contexto escolar. No caso dos gêmeos, a relação com seu irmão influencia diretamente esses dois fatores e, por isso, compreender as consequências da separação e manutenção deles na mesma sala é fundamental. Estudar a percepção das mães quanto às diversas consequências da experiência de separar ou não pode ampliar a visão sobre o tema, embasar melhor as decisões e contribuir para o enriquecimento da literatura.

\subsection{Objetivos e Hipóteses}

O objetivo foi comparar a percepção materna quanto as consequências dos gêmeos estudarem juntos ou separados em relação aos seguintes parâmetros: satisfação materna e gemelar, bem-estar gemelar, individualidade, desenvolvimento da personalidade, desempenho escolar, sociabilidade e melhora no relacionamento.

As hipóteses foram:

a) não haverá diferença entre gêmeos que estudam juntos e separados no que tange o desenvolvimento da individualidade, mas os que estudam juntos apresentarão maior sociabilidade, satisfação e bem-estar;

b) não haverá diferença entre os grupos em relação ao desempenho escolar; 


\subsection{Material e Métodos}

\subsubsection{Participantes}

A amostra foi composta de $\mathrm{N}=285$ mães de gêmeos brasileiros predominantemente da região Sudeste. A idade média das mães foi de 37,14 anos (DP = 5,69; mín. = 22; máx. = 50). O perfil sociodemográfico está detalhado na Tabela 7.

Tabela 7. Dados sociodemográficos das respondentes do Estudo 3

\begin{tabular}{llrr}
\hline Variável & \multicolumn{1}{c}{ Categoria } & N & \% \\
\hline & Ensino Fundamental Completo & 10 & 3.5 \\
Nível de Educação & Ensino Médio Completo & 83 & 29,1 \\
$(\mathbf{N}=\mathbf{2 8 5})$ & Ensino Superior Completo & 72 & 25,3 \\
& Pós-graduação & 120 & 42,1 \\
\hline & Até 1 salário mínimo & 12 & 4,2 \\
& $1-3$ & 57 & 20,0 \\
& $3-6$ & 66 & 23,2 \\
Renda* & $6-9$ & 48 & 16,8 \\
$(\mathbf{N}=\mathbf{2 8 5})$ & $9-12$ & 33 & 11,6 \\
& +13 & 50 & 17,5 \\
& Omissos & 19 & 6,7 \\
\hline & Sudeste & 200 & 70,2 \\
& Sul & 62 & 21,8 \\
Região & Centro-Oeste & 12 & 4,2 \\
$(\mathbf{N}=\mathbf{2 8 5})$ & Nordeste & 9 & 3,1 \\
& Norte & 2 & 0,7 \\
\hline
\end{tabular}

Fonte: Elaboração própria

Notas: * A renda foi informada em salários mínimos. O salário mínimo brasileiro de 2018 era $\mathrm{R} \$ 954,00$.

A idade média das 285 crianças foi de 5,68 anos $(\mathrm{DP}=2,11$; mín $=1$; máx $=11)$, totalizando 570 gêmeos, sendo que $\mathrm{N}=59$ pares estudavam em creche, $\mathrm{N}=122$ na pré-escola e $\mathrm{N}=104$ no Fundamental I (Tabela 8). 
Tabela 8. Características dos pares de gêmeos do Estudo 3

\begin{tabular}{llrr}
\hline Variável & Categoria & $\mathbf{N}$ & \% \\
\hline Zigosidade & Monozigóticos & 126 & $44,2 \%$ \\
Diagnosticada & Dizigóticos & 159 & $55,8 \%$ \\
$(\mathbf{N}=\mathbf{2 8 5})$ & Particular & 154 & $46,0 \%$ \\
Tipo de escola & Pública & 131 & $54,0 \%$ \\
\hline
\end{tabular}

Fonte: Elaboração própria

\subsubsection{Instrumentos}

Dois questionários foram utilizados: 1) Questionário de Zigosidade de Christiansen et al. (2003); e 2) Questionário de Gêmeos na Escola (elaboração própria). Para mais detalhes, consultar a subseção "instrumentos” do Estudo 1 (pág. 45)

\subsubsection{Procedimentos}

Todas as mães que participaram da pesquisa assinaram o Termo de Consentimento Livre e Esclarecido aprovado pelo Comitê de Ética em Pesquisa com Seres Humanos ( $\mathrm{n}^{\circ}$ 2.606.770) (Anexo A).

Para coleta de dados foi feita divulgação do QGE através das redes sociais e convite por e-mail às integrantes do Painel USP de Gêmeos.

\subsubsection{Análises}

Examinamos inicialmente a normalidade da amostra, através da distribuição dos dados e do teste de Kolmogorov-Smirnov, em relação aos seguintes parâmetros: satisfação dos gêmeos [D (284)=0,322, p < 0,001], satisfação das mães [D (284)=0,337, p < 0,001], bem-estar dos 
gêmeos [D $(284)=0,314, p<0,001]$, relacionamento [D $(284)=0,272, p<0,001]$, individualidade $[\mathrm{D}(284)=0,218, \mathrm{p}<0,001]$, desenvolvimento da personalidade [D (284)= $0,228, \mathrm{p}<0,001]$, desempenho escolar $[\mathrm{D}(284)=0,231, \mathrm{p}<0,001]$ e sociabilidade [D (284)= $0,244, p<0,001]$. Dado que todos os resultados apresentaram nível de significância menor do que 0,05 , podemos considerar que a distribuição dos dados não era normal.

Considerando a não normalidade da distribuição dos dados realizamos o teste nãoparamétrico de Kruskal-Wallis para comparar a percepção das mães de gêmeos de: a) MZ que estudavam juntos $(\mathrm{N}=81)$; b) $\mathrm{MZ}$ que estudavam separados $(\mathrm{N}=45)$; c) DZ que estudavam juntos $(\mathrm{N}=104)$; e d) DZ que estudavam separados $(\mathrm{N}=55)$. Para comparações dois-a-dois subsequentes foram feitos testes post-hoc de Mann-Whitney, usando a correção de Bonferroni. As análises quantitativas foram feitas com o software SPSS versão 24.

Por fim, realizamos uma análise textual através do programa IRAMUTEQ, versão 0,7, alpha 2. O recurso usado foi a análise de similitude que se baseia na teoria de grafos e possibilita identificar a co-ocorrência de palavras e a conexão entre elas (quanto mais espesso o nó, maior a co-ocorrência dos termos nos textos). Para ilustrar, selecionamos algumas respostas que exemplificam cada categoria destacada (Camargo \& Justo, 2013).

\subsection{Resultados}

A partir do relato das mães, o teste de Kruskal-Wallis mostrou que os grupos diferiram significativamente entre si quanto à satisfação dos gêmeos $[H(3)=100,06, p<0,001]$, individualidade $[\mathrm{H}(3)=33,423, \mathrm{p}<0,001]$, desenvolvimento da personalidade $[\mathrm{H}(3)=11,318$, $\mathrm{p}<0,01]$, bem-estar [H (3) $=49,938, \mathrm{p}<0,001]$, relacionamento entre gêmeos $[\mathrm{H}(3)=25,956$, $\mathrm{p}<0,001]$ e satisfação materna [H (3) = 30,725, $\mathrm{p}<0,001]$.

Testes de Mann-Whitney post-hoc mostraram que gêmeos que estudavam juntos, tanto MZ quanto DZ, foram considerados pelas mães como mais satisfeitos em comparação com os que estudavam separados $\left(\mathrm{U}_{\mathrm{MZ}}=102,699, \mathrm{p}<0,001\right.$ e $\left.\mathrm{U}_{\mathrm{DZ}}=81,878, \mathrm{p}<0,001\right)$. Além disso, na perspectiva das mães, estudar na mesma sala contribuiu de forma mais positiva para o bemestar $\left(\mathrm{U}_{\mathrm{MZ}}=68,912, \mathrm{p}<0,001\right.$ e $\left.\mathrm{U}_{\mathrm{DZ}}=61,746, \mathrm{p}<0,001\right)$ (Figura 7) e para o relacionamento dos gêmeos $\left(U_{M Z}=51,169, p=0,002\right.$ e $\left.U_{D Z}=46,393, p=0,002\right)$. 
Figura 7. Percepção das mães quanto ao bem-estar de gêmeos MZ e DZ que estudam juntos e

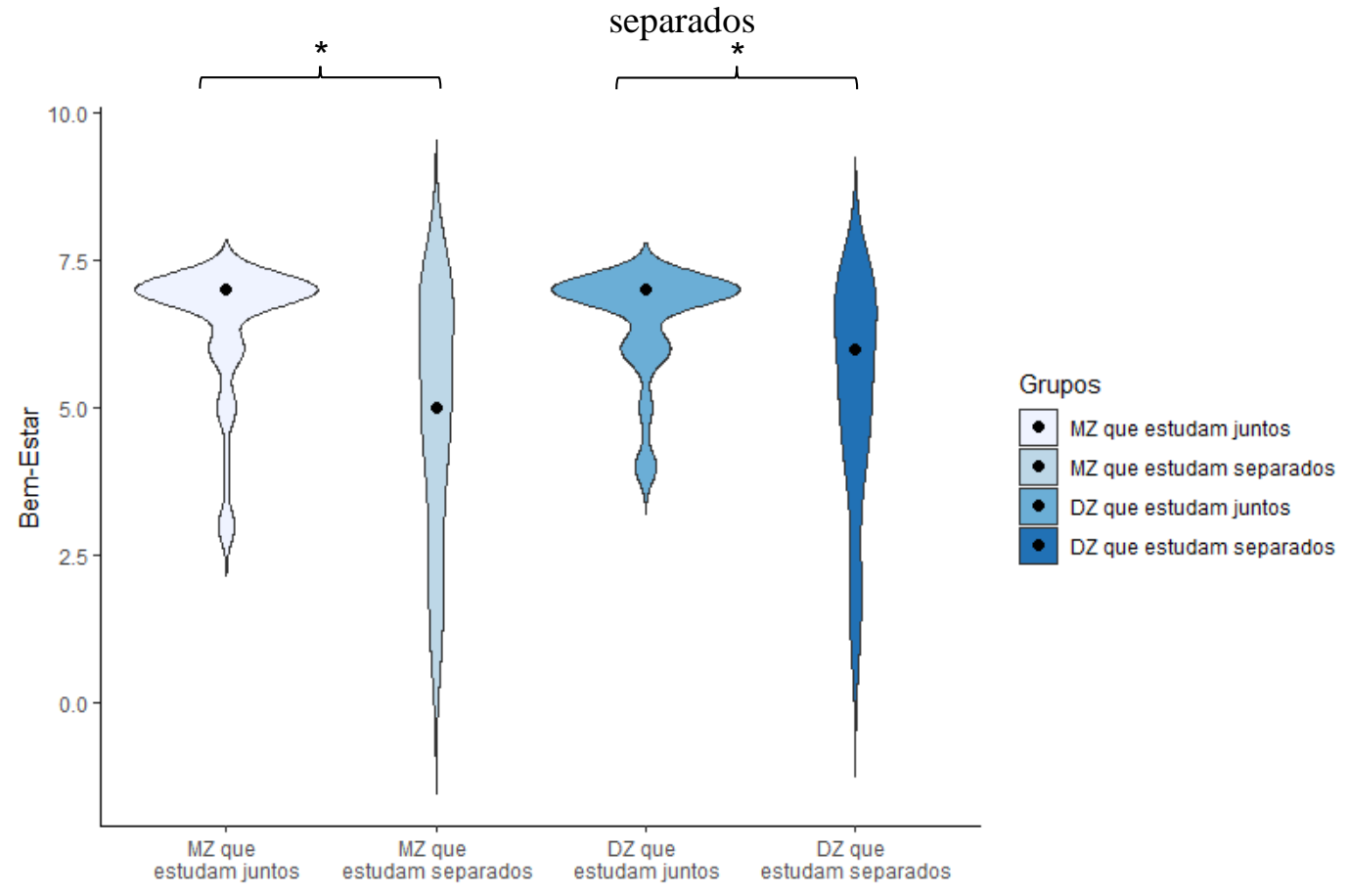

Fonte: Elaboração própria

Diferentemente dos outros parâmetros, a separação contribuiu significativamente para a individualidade dos gêmeos, independente da zigosidade $\left(\mathrm{U}_{\mathrm{MZ}}=47,432, \mathrm{p}=0,008\right.$ e $\mathrm{U}_{\mathrm{DZ}}=$ 62,673, $\mathrm{p}<0,001)$. Ainda, mães de DZ que estudavam separados perceberam uma maior diferenciação dos gêmeos quanto a personalidade, em comparação com as mães de DZ que estudavam juntos $(\mathrm{U}=38,455, \mathrm{p}=0,021)$. Entretanto, nenhuma diferenciação na personalidade foi percebida em MZ que estudavam juntos e separados $(U=18,211, p=0,214)$ (Figura 8).

Figura 8. Percepção das mães quanto ao desenvolvimento da personalidade de gêmeos MZ e DZ que estudam juntos e separados

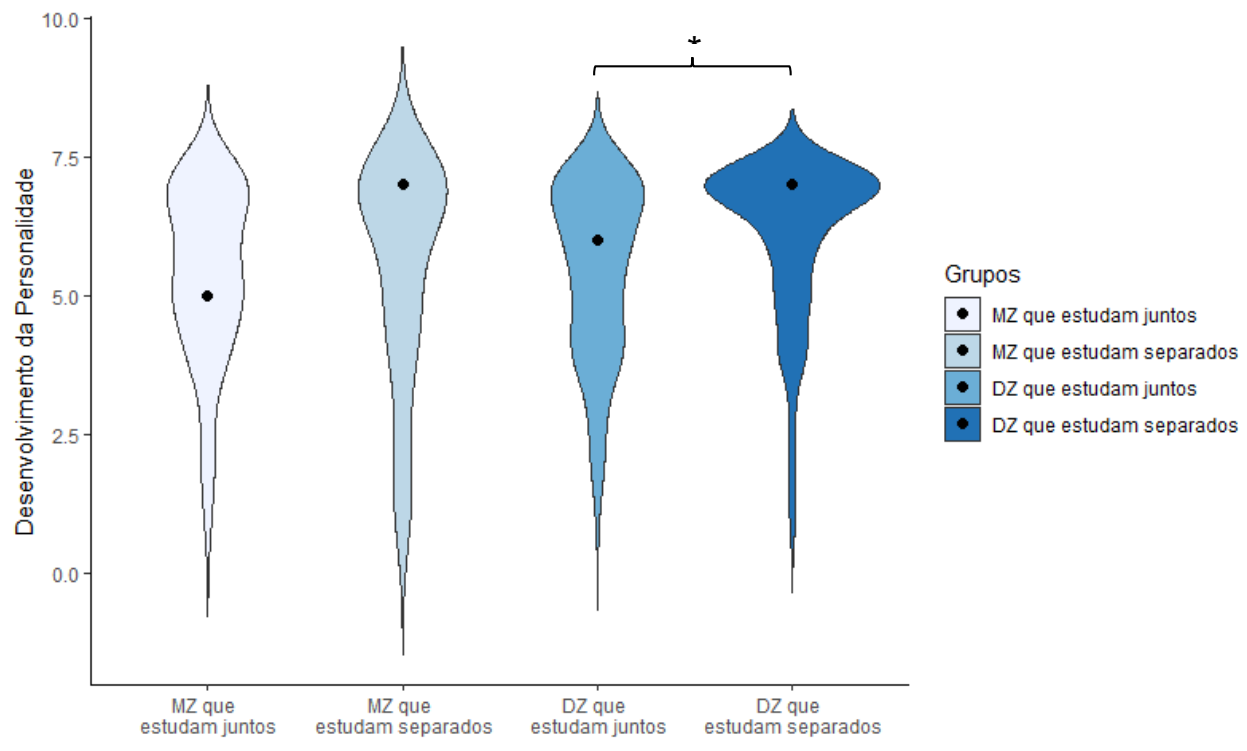


Fonte: Elaboração própria

Em relação a satisfação materna, mães de gêmeos que estudavam juntos estavam mais satisfeitas do que as mães dos que estudavam separados, independentemente da zigosidade $\left(\mathrm{U}_{\mathrm{MZ}}=51,76, \mathrm{p}=0,001\right.$ e $\left.\mathrm{U}_{\mathrm{DZ}}=47,886, \mathrm{p}=0,001\right)$.

Através dos testes post-hoc relatados acima, concluímos que a zigosidade parece não ter influência na maioria dos parâmetros, exceto no que diz respeito ao desenvolvimento da personalidade. Além disso, não houve diferença entre os grupos quanto à percepção materna de desempenho escolar $[\mathrm{H}(3)=0,929, \mathrm{p}=0,818]$ e sociabilidade $[\mathrm{H}(3)=3,255, \mathrm{p}=0,354]$.

Para verificar se havia outros aspectos positivos e negativos sobre a situação escolar, as mães responderam à seguinte pergunta aberta "Se você quiser compartilhar outros pontos positivos e negativos sobre gêmeos estudarem juntos/separados ou quiser fazer alguma observação sobre o tema, por favor, escreva abaixo". A partir da codificação das respostas realizamos duas análises de similitude, a primeira do grupo de mães de gêmeos que estudavam juntos e a segunda do grupo de mães dos que estudavam separados.

Para o primeiro grupo (Figura 9), os pontos positivos que mais se destacaram foi que estar ao lado do irmão(ã) propiciava maior segurança e apoio e que, mesmo estudando juntos, os gêmeos mantinham suas individualidades e seus amigos diferentes. A fim de ilustrar estas categorias selecionamos as respostas abaixo:

Meus gêmeos são um casal. $O$ fato de estarem juntos na mesma sala proporcionou segurança. [...] quando se sentem fragilizados buscam conforto no outro e muito rapidamente estão prontos para recomeçar sozinhos. Acho isso um grande ponto favorável. Eles conseguem desenvolver individualidade, pois se sentem seguros para isso (Respondente 847).

Acredito que estudar na mesma sala não se resume somente à questão da individualidade. Até porque, se for pensar por esse ângulo então eles não poderiam dormir juntos no mesmo quarto [...]. Trabalhar a individualidade delas começa em casa, com os pais, e continua com os familiares, amigos e escola. Cabe aos adultos que lidam com os gêmeos tratá-los como seres diferentes, individuais, em todos os sentidos (Respondente 1735). 
Figura 9. Análise de similitude dos pontos positivos e negativos de se estudar junto segundo a percepção materna

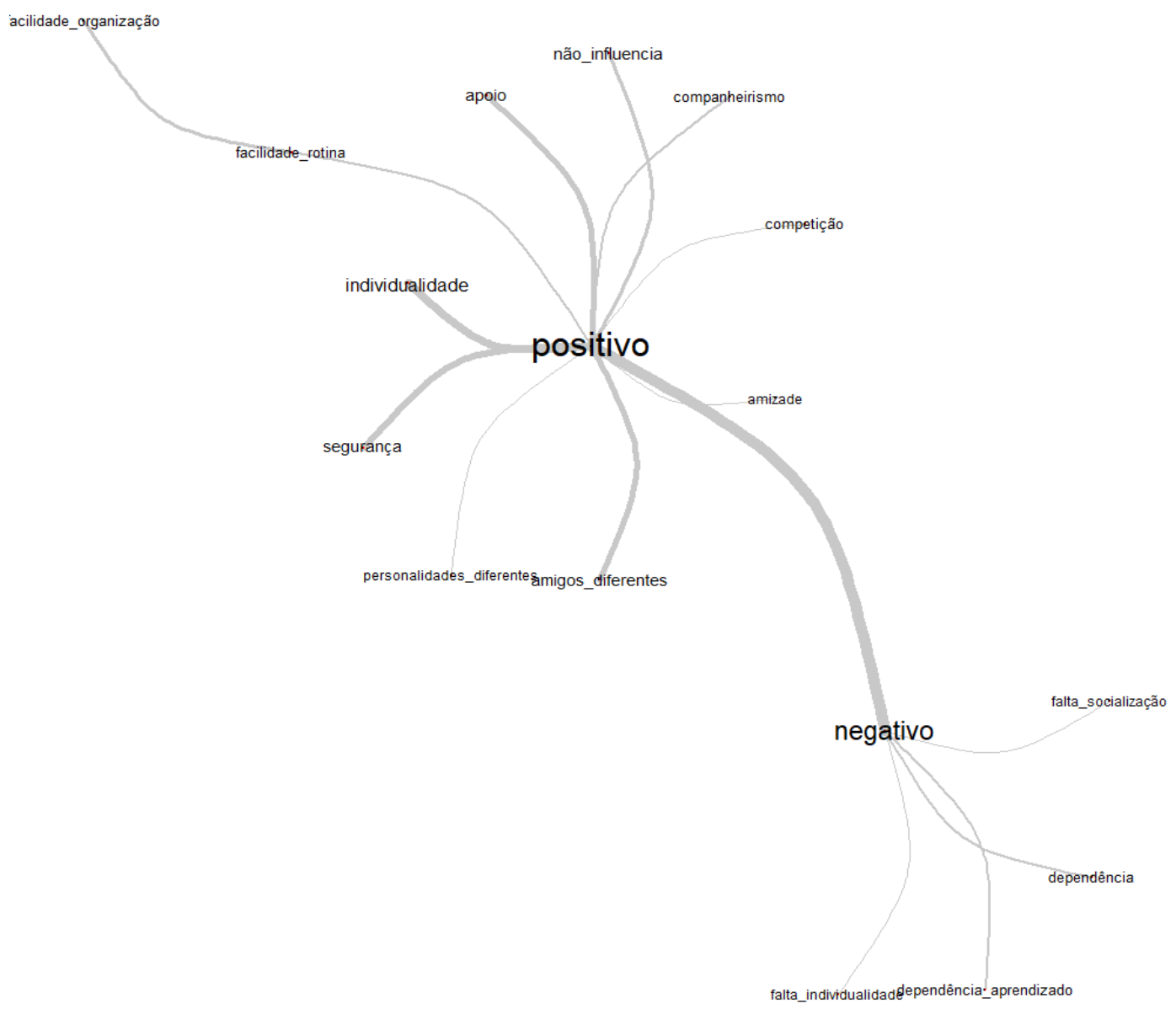

Fonte: elaboração própria

Além disso, as mães não tinham certeza se, de fato, estudar separado poderia contribuir para o desenvolvimento da individualidade e independência e, por isso, optaram por deixá-los juntos. A facilidade para os pais em relação a rotina e organização em termos escolares (lição de casa, participação de reunião, etc.) também foi citada.

No começo algumas pessoas me disseram que tinha que separar. Escolas que separavam impreterivelmente por motivos de individualidade e amigos diferentes. Discordei porque não vi base científica que comprove alterações justificáveis, cada um terá a sua conforme o desenvolvimento. [...] pesquisei e não tinha nenhuma pessoa gabaritada para me comprovar [...] então decidi que a escola não ia trazer isso para minha casa. Tinha uma escola que me disse que os gêmeos não se encontravam nem no intervalo do lanche, pensei: - será que ser gêmeos é uma doença? (Respondente 1347) 
Do ponto de vista dos pais, estudarem juntos facilita a organização do dia-adia dos gêmeos, uma vez que sendo a mesma professora, são os mesmos materiais, as mesmas lições, a mesma metodologia de ensino. [...]. No que tange à individualidade, personalidade, rendimento e boa relação entre eles não acredito que o fato de estudarem juntos influencie muito, pois observo que minhas filhas têm amigos diferentes, rendimentos diferentes e se comportam diferentemente, como qualquer outro indivíduo com suas características próprias e únicas [...] (Respondente 295).

Os principais pontos negativos destacados foram que estudar juntos intensifica a dependência dos gêmeos, tanto no relacionamento com o irmão quanto em situações de aprendizagem, além de prejudicar a individualidade. Os trechos a seguir ilustram esse ponto de vista:

Se a escola tivesse outra sala, talvez eu fizesse uma experiência de separá-las, elas têm um atraso muito grande de linguagem [...] e as vezes ao invés de ajudar, atrapalha. Um dia cheguei na sala e a professora disse que uma delas tinha feito a tarefa dela e da outra (Respondente 720)

Acredito e vejo na prática que juntos a adaptação sempre foi mais fácil e que ambos se sentem mais seguros [...]. Contudo, percebo que em muitos momentos o fato de estudarem na mesma sala acaba atrapalhando. Tendem ocorrer comparações, perda de autonomia e invasão do espaço alheio. Sendo assim a escola talvez seja o primeiro momento de fato onde a separação, embora dolorosa, ocorra. Isto trará futuramente aspectos positivos (Respondente 95)

Para o segundo grupo (Figura 10), estudar em salas distintas foi positivo para o desenvolvimento da individualidade, para a socialização e para um relacionamento mais saudável entre os gêmeos. Algumas mães disseram que os gêmeos tinham mais assuntos para conversar ao longo do dia, melhorando a interação quando se reencontravam. Os trechos abaixo ilustram essas categorias:

Observamos um "desabrochar" dos irmãos no ano em que foram separados de turma. Cada um definiu melhor seus interesses [...] sem perder a "parceria" de brincar e se defender característica de gêmeos. Além disso, a relação entre eles melhorou muito, na questão de conflitos no final do dia e respeito à vontade do outro. Estamos muito felizes com a decisão de separá-los na escola (Respondente 25).

Quando separaram a primeira vez, eu fiquei preocupada e as meninas aceitaram bem [...] vejo que foi a melhor escolha que fiz, pois elas têm coisas para contar uma para a outra, tem amigos distintos [...] as professoras ajudam muito, pois sabem que são gêmeas e sempre que fazem presentes uma professora faz para a outra (Respondente 483). 
A questão do controle mútuo entre gêmeos extrapola a escola, pois continua em casa. [...] O fato de estudarem separadamente é uma oportunidade de buscarem seus próprios amigos e até de conhecerem seus próprios limites e se conhecerem melhor (Respondente 767).

Figura 10. Análise de similitude dos pontos positivos e negativos de se estudar separado segundo a percepção materna

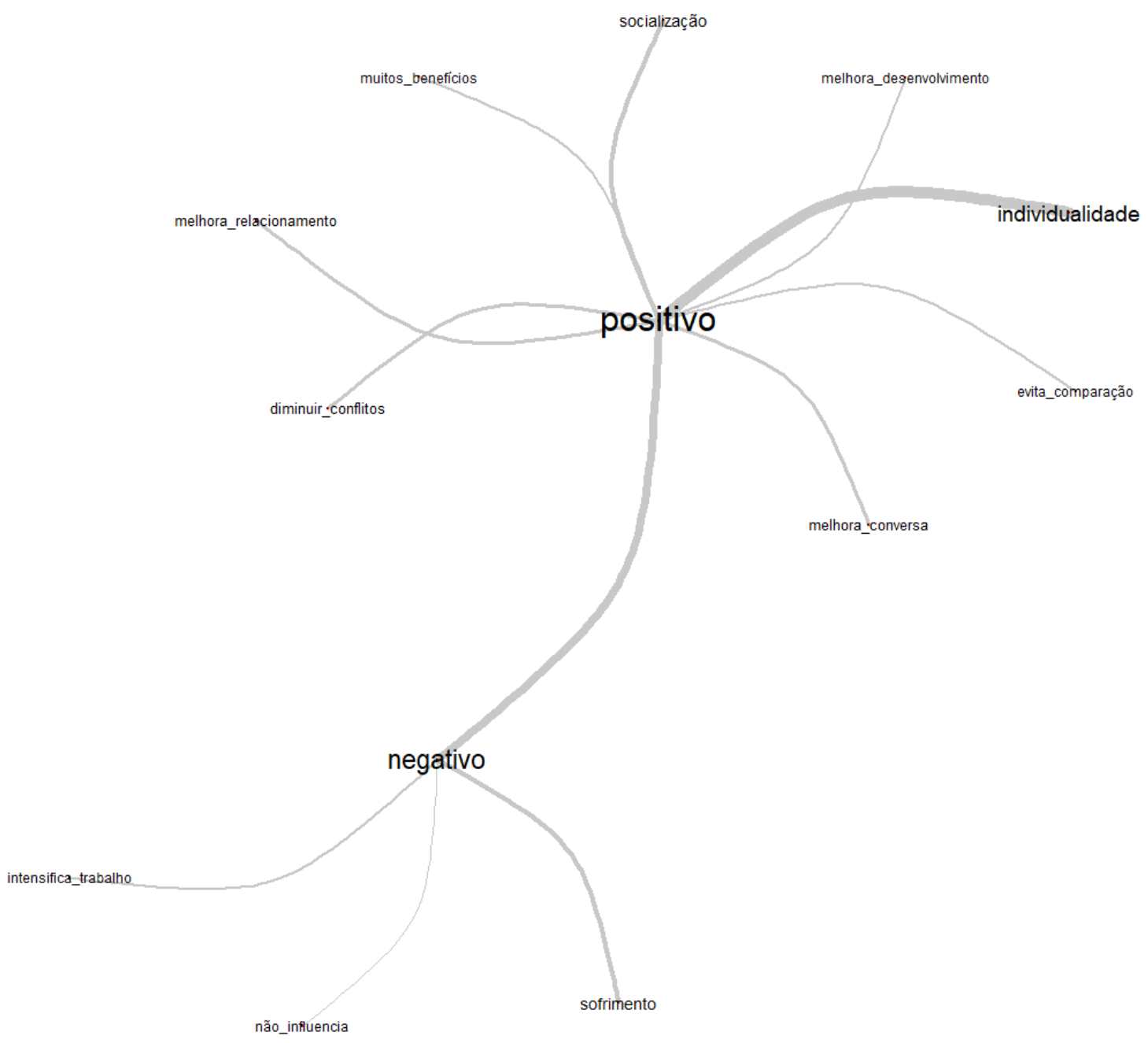

Fonte: Elaboração própria

A dificuldade inicial da separação, decorrente do sofrimento dos gêmeos, foi um dos pontos negativos mais citados. Além disso, estudar em salas distintas parece intensificar o trabalho materno em relação a rotina dos filhos.

[...] agora meus gêmeos já foram separados com apenas 4 anos e estão sofrendo muito com a separação acho que a mãe deveria escolher quando separar os filhos e não a escola, acho eles muito novinhos para a separação. 
Tá doendo neles e em mim... e ainda mais que são univitelinos... (Respondente 257).

É difícil participar das reuniões de pais por serem no mesmo dia e horário. Às vezes, as crianças fazem passeios e as outras não, sempre gera um desconforto (Respondente 478).

É importante, na hora de separar as crianças de sala, fazer uma preparação, com a ajuda da escola. No meu caso, não fiz, e a adaptação de uma delas foi bem difícil. A que parecia ser mais segura, colocamos em outra sala, mas na verdade ela era totalmente dependente de cuidar da irmã e sofreu bastante. Mas depois da adaptação feita, com certeza, considero uma decisão acertada (Respondente 1583).

\subsection{Discussão}

Ainda que nenhuma medida psicométrica tenha sido utilizada para verificar o bem-estar e só tenhamos considerado a percepção materna, nossos resultados mostraram que gêmeos que estudavam juntos tinham melhor bem-estar e eram mais satisfeitos com a situação escolar, independente da zigosidade. Gêmeos procuram seu irmão como apoio em momentos de estresse e como uma base de segurança, por isso, tendem a preferir ficar juntos (Fraley \& Tancredy, 2012; Tancredy \& Fraley, 2006). Ao serem separados de forma precoce podem apresentar sentimentos como tristeza, raiva, solidão (Grime, 2008), podem se sentir incompletos e ansiosos com o paradeiro de seu irmão (Ainslie, 1997) e, por isso, seu bem-estar pode ser prejudicado com a separação. Portanto, o co-gêmeo parece ser um fator protetivo de saúde mental em um ambiente que provoca estresse (Sandbank, 1999).

Para as mães, estudar junto também contribuiu positivamente para o relacionamento entre os filhos. A consequência disso pode ser interessante, já que a qualidade do relacionamento gemelar é importante para os pais. Quando há a possibilidade de escolha, mães optam por separá-los apenas quando há risco prévio (i.e., brigas frequentes, estarem tão apegados a ponto de não procurarem outros amigos, um dos gêmeos apresentar submissão e/ou timidez extrema) (Staton et al., 2012). Por isso, acreditamos que os gêmeos que estudavam juntos em nossa amostra, provavelmente, já tinham uma relação considerada boa e aqueles que foram separados já apresentavam alguma dificuldade em se relacionar um com o outro.

O desenvolvimento do indivíduo e a construção do self estão intimamente ligados com o quanto os próprios gêmeos e os outros em seu entorno os percebem como uma unidade ou como 
seres únicos (Hay \& Preedy, 2006), assim, eles podem experienciar ambiguidade e confusão em relação a identidade (Ainslie, 1997). Por isso, o desenvolvimento da individidualidade costuma ser a principal preocupação levantada por pais e educadores. Entretanto, ainda não há evidências científicas sobre práticas pedagógicas especificas que promovam a individualidade dos gêmeos (Staton et al., 2012), nem de que a separação escolar ajude a desenvolvê-la. O presente estudo verificou que, sob a perspectiva materna, gêmeos que estudavam separados apresentaram maior individualidade do que aqueles que estudavam juntos e este ponto também foi o principal aspecto positivo da separação relatado pelas mães nas respostas abertas. Estudar separado evita comparações por parte de professores e colegas, além de proporcionar amizades e experiências diferentes para ambas as crianças da dupla (Hay \& Preedy, 2006), o que pode contribuir para a individualidade.

Além disso, de acordo com as mães, DZ que estudavam separados desenvolveram mais a sua personalidade única do que DZ que estudavam juntos, entretanto este efeito não foi encontrado para MZ. Um estudo recente mostra que a herdabilidade da personalidade é em média 40\%, ou seja, há pronunciada influência genética em seu desenvolvimento (Vukasović \& Bratko, 2015), o que pode explicar o efeito diferente para MZ. É importante salientar que este estudo não quer dizer que a criação familiar não importa e sim que não é só o ambiente compartilhado que torna os gêmeos parecidos. Na verdade, o compartilhamento de genes é um fator bastante decisivo para a personalidade ser semelhante (N. Segal \& Russell, 1992). Isso pode explicar o porquê de a separação escolar não ter contribuído para o desenvolvimento de personalidades distintas em gêmeos MZ. Já a personalidade de DZ tende a ser mais diferente devido seu menor compartilhamento genético, portanto, separá-los de ambiente intensificaria diferenças já existentes.

Uma outra explicação possível para o achado da personalidade é que mães de MZ acham seus filhos mais parecidos e ressaltam as características que eles têm em comum, o chamado efeito de assimilação, enquanto mães de DZ tendem a focar nas diferenças entre os gêmeos (Plomin et al., 1990; Saudino, Cherny \& Plomin, 2000). Isso pode influenciar a percepção materna em relação a personalidade, enviesando a real consequência da separação e influência da zigosidade. É importante ressaltar que, neste estudo, não fornecemos nenhuma definição de personalidade para as mães e nem foi perguntado a elas o que entendiam por personalidade.

Apesar dos estudos terem como foco as consequências para os gêmeos, é interessante e necessário entendermos as consequências da situação escolar para as mães. A satisfação das mães dos que estudavam juntos foi maior do que as dos gêmeos que estudavam separados. Este resultado pode ser justificado pela facilidade na organização e participação escolar das mães, 
assim como ressaltado nas respostas abertas. Em 2012, Staton e colegas verificaram que mães de gêmeos apontavam a praticidade como um importante fator na decisão de mantê-los juntos. Uma revisão da literatura realizada em 2014 mostrou que mães de gêmeos enfrentam mais estresse e uma rotina mais intensa do que mães de singulares (Andrade et al., 2014). Por isso ter uma rotina escolar mais prática pode ser de grande ajuda para elas. Quando os filhos estudam na mesma sala, as mães podem participar de forma mais frequente das reuniões e de eventos escolares, ao invés de terem que se dividir, e podem organizar melhor as demandas da professora. Além disso, estudar na mesma sala pode tranquilizar as mães em relação a entrada das crianças na escola, uma vez que um gêmeo estaria apoiando o outro e a conexão gemelar não estaria sendo rompida (Staton et al., 2012).

Assim como em estudos anteriores (e.g van Leuween et al., 2005; White et al., 2018), não houve diferença no desempenho acadêmico de gêmeos que estudavam juntos ou separados, segundo a percepção das mães. Além do desempenho acadêmico, outros estudos também não encontraram diferenças nas habilidades cognitivas entre os dois grupos, nem interferência da zigosidade e sexo da dupla (Polderman et al., 2010; White et al., 2018).

Em relação a sociabilidade, achávamos que o gêmeo propiciaria um contexto de apoio para o irmão explorar novas amizades, especialmente em MZ (Goymour, 2017), por isso a sociabilidade seria maior naqueles que estudavam juntos. Entretanto, para a nossa amostra, não houve diferença de sociabilidade entre os grupos. Nós hipotetizamos que a gemelaridade é benéfica para a competência social, independentemente da presença do gêmeo no mesmo ambiente. Gêmeos tem que negociar e compartilhar desde o início da vida, o que contribui para o aprendizado social (Thorpe \& Dunby, 2006). Além disso, crescer com um irmão auxilia no desenvolvimento da Teoria da Mente, habilidade que promove a compreensão da perspectiva do outro (Cassidy et al., 2005). Crianças que têm uma alta competência em habilidades sociais, como negociação e compreensão do outro, provavelmente construirão uma rede de amizade que fornece apoio e se desenvolverão positivamente (Dunn, 2018).

O presente estudo trouxe importantes contribuições no sentido de compreender qual a percepção das mães sobre as consequências da separação ou manutenção de gêmeos na mesma sala de aula. Nossos resultados mostraram que separar os gêmeos pode ser benéfico para desenvolver a individualidade, ao passo que mantê-los juntos pode contribuir para o bem-estar e para a satisfação deles. Entretanto, os efeitos da situação escolar dependem das características individuais dos gêmeos e das diferentes percepções sobre a experiência em sala de aula, seja das mães, dos filhos ou dos próprios professores. Por isso, é necessário considerar caso a caso, estabelecer um diálogo entre os envolvidos e fazer um monitoramento constante para verificar 
o que está funcionando bem ou piorando com a situação escolar, a fim de realizar mudanças quando necessário.

\section{DISCUSSÃO GERAL}

O presente trabalho é pioneiro no Brasil ao realizar um estudo sobre as causas e consequências da separação escolar de gêmeos sob a perspectiva materna. Dado que a maioria das pesquisas sobre relacionamento entre gêmeos e gêmeos na escola foi realizada na Europa, América do Norte e Oceania (e.g. Gordon, 2014; Gleeson et al., 1990; Preedy, 1999), nossos resultados acrescentam à literatura a visão da cultura latino-americana, especificamente a brasileira, sobre o contexto escolar de gêmeos.

A maioria das escolas do nosso estudo é caracterizada pelas mães como flexível em relação a separá-los ou não, apesar de $25 \%$ relatarem que as escolas tinham uma prática rígida de separação. De forma geral, a maioria dos gêmeos estudavam juntos, resultado do modelo mais autônomo-relacional (Seidl-de-Moura et al., 2008) que o Brasil apresenta, sendo que as mães participaram ativamente da decisão, especialmente em instituições particulares.

O presente estudo também abordou a situação escolar dos gêmeos como parte da expressão das crenças e práticas maternas de criação. Em relação as crenças maternas, as mães consideraram o relacionamento como o fator de maior importância para a tomada de decisão e, nas respostas abertas, elas complementaram que o conflito e a dominância são os aspectos que mais contribuem para a decisão a favor da separação. De fato, foi encontrado que os gêmeos que apresentavam maior rivalidade entre si eram mais separados. Sob a perspectiva evolucionista, ter a mesma idade significa compartilhar as mesmas necessidades em relação aos recursos limitados oferecidos pelos pais e, consequentemente, algumas formas de conflito podem ocorrer (Trivers, 1972). Por isso, conflito e rivalidade são dimensões muito interligadas (H. Segal \& Knafo-Noam, 2019). Logo, as mães podem optar por separar os gêmeos esperando que a rivalidade e o conflito diminuam. Além disso, MZ na faixa etária de 6-9 anos que estudavam separados também apresentaram maior dominância, provavelmente em uma tentativa de estabelecer uma assimetria na relação a fim de conquistar sua individualidade, entretanto o bem-estar do indivíduo mais submisso pode ser prejudicado (Ebeling et al., 2003). 
Hipotetizamos que nessa faixa etária as mães já se sentem mais seguras em realizar a separação, pois os filhos estariam no mínimo há dois anos na escola e mais acostumados com o ambiente.

As mães relataram que a idade da dupla é o segundo fator que mais influencia a decisão, seguido de zigosidade e sexo. Na prática, gêmeos mais novos eram menos separados do que o esperado, provavelmente por conta do relacionamento proporcionar suporte emocional facilitando assim a adaptação ao novo ambiente escolar nos anos iniciais (Staton et al., 2012). Corroborando a argumentação, no Estudo 3, o apoio emocional foi considerado o principal benefício pelas mães de gêmeos que estudavam juntos. A zigosidade e o sexo da dupla pareceram realmente não exercer influência na prática de separação dentro da nossa amostra.

Sabe-se que as crenças e práticas de criação são pautadas pela cultura na qual a mãe está inserida (Oliva et al., 2017) e sofrem influências de fatores como, por exemplo, o tamanho da cidade e o status socioeconômico (Seidl-de-Moura et al., 2008). Encontramos que mães de cidades grandes e com maior renda separavam mais seus gêmeos e que estas características estão relacionadas com a valorização de autonomia e individualidade que elas esperam garantir ao separar seus filhos.

Somando-se à estas análises, exploramos e comparamos, sob a percepção materna, as consequências da decisão de separar ou manter os gêmeos na mesma sala. Gêmeos que estudavam juntos apresentaram maior bem-estar, uma melhora na relação e maior satisfação com a situação escolar. A relação gemelar fornece suporte emocional e um porto seguro para os indivíduos explorarem o ambiente, o que pode servir como fator protetivo de saúde mental no ambiente escolar (Sandbank, 1999). Entretanto, os que estudavam separados apresentaram maior individualidade do que aqueles que estudavam juntos, provavelmente porque a separação proporciona experiências únicas, amigos diferentes e evita comparação com o irmão (Hay \& Preedy, 2006). No que tange o desenvolvimento da personalidade única, encontramos diferença apenas para DZ que estudam separados.

Não tivemos a pretensão de responder à pergunta "gêmeos devem estudar juntos ou separados? ", uma vez que já é consenso de pesquisas anteriores que essa é uma resposta que não deve ser generalizada. Existem muitos mitos sobre o relacionamento entre gêmeos $(\mathrm{N}$. Segal, 2017) e, frequentemente, as pessoas os encaram como um grupo homogêneo (Beauchamp \& Brooks, 2003). Nosso estudo mostrou que apesar de haver alguns padrões, as motivações maternas são baseadas em crenças distintas e influenciadas por fatores diversos, os gêmeos têm relacionamentos únicos e que mesmo no nível intra-par pode haver discordâncias, onde um quer ficar junto e o outro separado. Por isso, enfatizamos aqui a importância de educadores e responsáveis realizarem a decisão com base em evidências e não em "achismos". 
É necessário considerar as peculiaridades de ser gêmeo, conhecer a dinâmica de relacionamento da dupla, mas sem esquecer dos indivíduos únicos que a compõem. Por fim, é importante também levar em consideração o bem-estar emocional da família, verificar se estão enfrentando estresse em relação à rotina, à saúde e necessidades educacionais especiais da dupla.

\subsection{Limitações dos estudos}

Cuidados com a generalização dos resultados devem ser tomados, uma vez que a amostra é altamente escolarizada e predominantemente da região Sudeste e Sul, portanto, não é representativa da população brasileira como um todo.

Além disso, no Estudo 2, não foi perguntado às mães quem foi o autor da decisão de separar ou não os gêmeos na escola. Essa informação poderia nos dar um melhor parâmetro do quanto, de fato, o relacionamento influenciou na decisão de separação.

\subsection{Futuros estudos}

Para compreender melhor a percepção de educadores brasileiros (professores, coordenadores e diretores) sobre a separação escolar de gêmeos, futuras pesquisas devem ser realizadas com esse público. Ainda, estudos têm mostrado que a opinião dos gêmeos é pouco ouvida (Gordon, 2014; Staton et al., 2012), por isso, levar em conta a perspectiva deles é fundamental. Neste caso, diferenças em função de zigosidade, sexo e idade poderiam ser exploradas.

Em relação às causas de separação escolar, mais estudos podem ser realizados para comparar as práticas e crenças maternas e paternas de diferentes regiões brasileiras sobre a separação de gêmeos na escola, correlacionando até mesmo com questionários sobre estilos e etnoteorias parentais. Dado que o relacionamento entre gêmeos está diretamente associado com bem-estar, seria interessante realizar estudos longitudinais sobre o bem-estar emocional de gêmeos que estudam juntos e separados. 


\section{CONCLUSÃO}

Diferentemente do encontrado em países como os EUA, a maioria dos gêmeos brasileiros da nossa amostra estudavam juntos, interpretamos que isto aconteça por diferenças culturais em relação a valorização da autonomia e individualidade. As escolas costumam ser flexíveis quanto à pratica de separação e a maioria das mães participam da decisão de separar ou não os gêmeos, especialmente em escolas particulares. Esse estudo foi o primeiro, a nível internacional, em considerar a decisão sobre a situação escolar como reflexo das crenças parentais e encontrou que mães que moravam em cidades grandes e tinham maior renda separavam mais os seus filhos como um meio de estimular a individualidade e independência. Ainda, elas preferem que os gêmeos estudem juntos nos primeiros anos escolares, provavelmente para garantir suporte emocional e segurança no novo ambiente.

Nosso estudo mostrou que gêmeos que apresentavam mais rivalidade eram mais separados, independente da zigosidade. Gêmeos MZ que eram mais dominantes também eram mais separados na faixa etária de 6 a 9 anos, provavelmente porque nessa idade as mães já se sentem mais seguras em realizar a separação com o objetivo de que ela melhore o relacionamento de seus filhos. Além disso, observamos que as reações dos gêmeos à separação podem ser diferentes. Dentro de um mesmo par, um gêmeo pode querer ou gostar de ficar separado de seu irmão, enquanto o outro pode não aceitar. Estes achados contribuem para a desconstrução de estereótipos que consideram os gêmeos como unidades que têm sentimentos, vontades e interesses idênticos e também reforçam que o tipo de relacionamento é um dos fatores que mais influencia as decisões maternas.

Como consequências da situação escolar, segundo a percepção materna, gêmeos que estudavam separados desenvolviam melhor sua individualidade que os demais, uma vez que o ambiente distinto proporciona amigos e experiências diferentes. Entretanto, os relatos das mães mostraram que o bem-estar, a satisfação dos gêmeos, a satisfação materna e a qualidade do relacionamento foram maiores naqueles que estudavam juntos, demonstrando que o co-gêmeo pode ser um fator protetivo de saúde mental e que a rotina da mãe pode ser facilitada quando os filhos estudam juntos. Por fim, não houve diferença entre a sociabilidade e desempenho escolar de gêmeos que estudavam juntos e separados, indo ao encontro dos achados internacionais. 
Esperamos que o presente trabalho seja um importante instrumento de reflexão e consulta para responsáveis e professores, e um ponto de partida para futuras pesquisas sobre o tema. Nossos resultados sugerem que as escolhas das mães em relação a separar ou não os filhos podem ser informativos para políticas e práticas educacionais para gêmeos. É necessária uma atenção e sensibilidade cada vez maior para esse público, considerando as consequências psicológicas e educacionais que práticas mal embasadas podem acarretar. 


\section{REFERÊNCIAS BIBLIOGRÁFICAS}

Ainslie, R. C. (1997). The psychology of twinship 2.ed.. Maryland/USA: Jason Aronson.

Ainsworth, M. D. S. (1991). Attachments and other affectional bond across the life cycle. In C.M Parkes, J. Stevenson- Hinde \& P. Marris (Eds.), Attachments across the life cycle. New York, USA: Routledge.

Anderson, D. J. (1990). On the evolution of human brood size. Evolution, v. 44(2), 438-440. doi: $10.2307 / 2409420$

Andrade, L., Martins, M. M., Angelo, M., \& Martinho, J. (2014). Families with twins-a systematic review. Texto \& Contexto-Enfermagem, 23(3), 758-766. doi: 10.1590/010407072014002950013

Bacon, K. (2010). Twins in Society: Parents, Bodies, Space and Talk. England: Palgrave Mcmillan.

Beauchamp, H. M., \& Brooks Jr, L. J. (2003). The perceptions, policy, and practice of educating twins: A review. Psychology in the Schools, 40(4), 429-438. doi: 10.1002/pits.10097

Beiguelman, B. (2008). O Estudo de Gêmeos. Ribeirão Preto, SP/Brazil: SBG.

Benute, G. R.G., Nozzella, D. C. R., Prohaska, C., Liao, A., de Lucia, M.C.S., \& Zugaib, M. (2013). Twin Pregnancies: Evaluation of Major Depression, Stress, and Social Support. Twin Research and Human Genetics, 16(2), 629-633. doi: 10.1017/thg.2012.153.

Blinckstein, I., \& Keith, L. G. (2007). On the possible cause of monozygotic twinning: lessons from the 9-banded armadillo and from assisted reproduction. Twin Research and Human Genetics, 10 (2), 394-399. doi: 10.1375/twin.10.2.394

Bowlby, J. (1969). Attachment and loss: Vol I. Attachment. 2 a ed. New York, USA: Basic Books.

Camargo, B. V. \& Justo, A. M. (2013). IRAMUTEQ: Um software gratuito para análise de dados textuais. Temas em Psicologia, 21(2), 513-518. doi: 10.9788/TP2013.2-16

Campbell, A. (2008). Attachment, aggression and affiliation: the role of oxytocin in female social behavior. Biological psychology, 77(1), 1-10.

Campos, C. R. (2018). Qualidade de vida infantil e sua influência no contexto escolar. In: T.C Nakano (Org.). Psicologia Positiva Aplicada à Educação. São Paulo, SP/Brazil: Vetor Editora.

Caniato, R. N., Alvarenga, M.E., Stich, H.L., Jansen, H., \& Baune, B.T. (2010). Kindergarten attendance may reduce developmental impairments in children: Results from the Bavarian Pre-School Morbidity Survey. Scandinavian Journal of Public Health, 38, 580-586. doi: $10.1177 / 1403494810376558$

Cardoso-dos-Santos, A. C., Boquett, J. A., Oliveira, M. Z. D., Callegari-Jacques, S. M., Barbian, M. H., Sanseverino, M. T. V., ... \& Faccini, L. S. (2018). Twin peaks: a spatial and temporal study of twinning rates in Brazil. PLOS ONE. 13 (7), 14. doi: 10.1371/journal.pone.0200885 
Carlo, G., Koller, S., Raffaelli, M., \& Guzman, M. R.T. (2007) Culture-Related Strengths Among Latin American Familie. Marriage \& Family Reviews, 41, 3-4, 335-360. doi: 10.1300/J002v41n03_06, 2007.

Cassidy, K., Fineburg, D., Brown, K., \& Perkins, A. (2005). Theory of mind may be contagious, but you don't catch it from your twin. Child Development, 76, 97-106. doi: 10.1111/j.14678624.2005.00832.x

Caya, M. L., Liem, J. H. (1998). The role of sibling conflict in high-conflict families. America Journal of Orthopsychiatry, 68, 327-333. doi: 10.1037/h0080342

Chapman, C.A., Walker, S., \& Lefebre, L. (1990). Reproductive strategies of primates: The influence of body size and diet on litter size. Primates, 31(1), 1-13. Recuperado de: https://www.researchgate.net/profile/Colin_Chapman8/publication/225691028_Reproducti ve_strategies_of_primates_The_influence_of_body_size_and_diet_on_litter_size/links/0c9 6052ac6ef1c079e000000.pdf

Christiansen, L., Frederiksen, H., Schousboe, K., Skytthe, A., Von Wurmb-Schwark, N., Christensen, K., \& Kyvik, K. (2003). Age- and sex-differences in the validity of questionnaire-based zygosity in twins. Twin Research, 6, 275-258. doi: $10.1375 / 136905203322296610$.

DiLalla, L. F., \& Mullineaux, P. Y. (2008). The effect of classroom environment on problem behaviors: A twin study. Journal of School Psychology, 46(2), 107-128. Doi: 10.1016/j.jsp.2007.02.001

Dorneles, C.P., \& Schimdt, V.Z. (2015). Relação materna na construção de Identidade de Gêmeos. Revista de Psicologia da IMED, 7(2), 48-57. doi: 10.18256/2175-5027/psicoimed.v7n2p48-57

Douglas, M. (1957). Animals in Lele religious thought. In: J, MIDDLETON. Myth and Cosmos (pp. 46-58). New York, USA: The Natural History Press.

Dumontheil, I., Apperly, I. A., \& Blakemore, S. J. (2010). Online usage of theory of mind continues to develop in late adolescence. Developmental science, 13(2), 331-338. doi: 10.1111/j.1467-7687.2009.00888.x

Dunn, J. (2018). Sibling relationships across the life-span. In D. Hindle \& S. Sherwin-White (Eds.), Sibling Matters: A Psychoanalytic, Developmental, and Systemic approach (pp. 6981). Abingdon, UK: Routledge.

Dunn, J., Deater-Deckard, K., \& Pickering, K. (1999) Siblings, parents, and partners: Family relationships within a longitudinal community study. Journal of Child Psychology and Psychiatry, 40, 1025-1037. doi: 10.1017/S0021963099004369

Dunn, J., Stocker, C., \& Plomin, R. (1990). Assessing the relationship between young siblings: A research note. Journal of Child Psychology and Psychiatry, 31, 983-991. doi: 10.1111/j.1469-7610.1990.tb00839.x

Ebeling, H., Porkka, T., Penninkilampi-Kerola, V., Berg, E., Järvi, S., \& Moilanen, I. (2003). Inter-twin relationships and mental health. Twin Research and Human Genetics, 6(4), 334343. doi: 10.1375/twin.6.4.334 
Ely, J. J., Frels, W.L., Howell, S., Izard, M. K., Keeling, M.E., \& Lee, D.R. Twinning and heteropaternity in chimpanzees (Pan troglodytes). (2006). American Journal of Physical Anthropology, 130 (1), 96-102, 2006. doi: 10.1002/ajpa.20310

Ferreira, I.F, Short P.C.A., Lucci, T.K., Crispim, A.C., Reali, T., Marty, E.S., Rocha, V., Grinberg, A., Segal, N., Segal, H., Knafo-Noam, A., Otta, E. (no prelo). Twin relationships from infancy to preadolescence: Influence of zygosity, sex and age in Brazilian twins. Journal of Family Psychology.

Forbes, L.S. The evolutionary biology of spontaneous abortion in humans. (1997). Trend Ecology and Evolution, 12 (11), 446-450. doi: 10.1016/s0169-5347(97)01179-8

Fortuna, K., Goldner, I., \& Knafo-Noam, A. (2010). Twin relationships: A comparison across monozygotic twins, dizygotic twins, and nontwin siblings in early childhood. Family Science, 1, 205-211. doi: 10.1080/19424620.2010.569367

Fraley, R. C., \& Davis, K. E. (1997). Attachment formation and transfer in young adults' close friendships and romantic relationships. Personal Relationships, 4, 131-144. doi: 10.1111/j.1475-6811.1997.tb00135.x

Fraley, R. C., \& Tancredy, C. M. (2012). Twin and sibling attachment in a nationally representative sample. Personality and Social Psychology Bulletin, 38(3), 308-316. doi: $10.1177 / 0146167211432936$

Gatz, M., Harris, J.R., Kaprio, J., McGue, M., Smith, N.L., Snieder, H., ... \& Butler, D.A. (2015). Cohort Profile: The National Academy of Sciences-National Research Council Twin Registry (NAS-NRC Twin Registry). Internacional Journal of Epidemiology, 44 (3), 819825. doi: 10.1093/ije/dyu181

Gleeson, C. Hay, D.A., Johnston, C.J., \& Theobald, T.M. (1990). "Twins in school": An Australia-wide program. Acta Geneticae Medicae et Gemellologiae, 39, 231-244. doi: $10.1017 / \mathrm{s} 0001566000005468$

Goossens, B., Kapar, M. D., Kahar, S., \& Ancrenaz, M. (2012). First sighting of Bornean orangutan twins in the wild. Asian Primates Journal, 2(1), 12-14.

Gordon, L. M. Twins and Kindergarten Separation: Divergent Beliefs of Principals, Teachers, Parents and Twins. (2014). Educational Policy, 29 (4), 583-616. doi: $10.1177 / 0895904813510778$

Goymour, K.L. (2017). The Impact of Same and Separate Classroom Placements on the Social Adjustment of Identical and Non-Identical Same-Sex Twins at School Entry (Tese de Doutorado, University of Southampton, UK). Recuperado de: https://eprints.soton.ac.uk/415977/

Grime, J.J. (2008). The Educational Effect of Forced Separation on Twins (Tese de Doutorado, The University of Toledo, Ohio). Recuperado de http://rave.ohiolink.edu/etdc/view?acc_num=toledo1224685321

Guffler, H. (1996). Yamba twin ritual. Anthropos, 91, 33-51. Recuperado de: https://www.jstor.org/stable/40465271?seq=1 
Hamilton, W.D. (1964). The genetical evolution of social behavior. Journal of Theoretical Biology, 7, 1-52. doi: 10.1016/0022-5193(64)90039-6

Harkness, S., \& Super, C. M. (1986) The Developmental Niche: A Conceptualization at the Interface of Child and Culture. International Journal of Behavior Development, 9, 545 569. doi: 10.1177/016502548600900409

Harlow, H. F.\& Zimmermann, R. R. (1959). Affectional responses in the infant monkey. Science, 130 (3373), 421-432. doi: 10.1126/science.130.3373.421

Hay, D. A., Preedy, P. (2006). Meeting de educational needs of multiple birth children. Early Human Development, 82, 397-403. doi: 10.1016/j.earlhumdev.2006.03.010

Hrdy, S. B. (2011). Mothers and others. Cambridge, MA: Harvard University Press.

Huang, T., Gao, W., Lv, J., Yu, C., Wu, T., Wang, S., .. \& Li, L. (2019). The Chinese National Twin Registry: A Unique Data Source for Systems Epidemiology of Complex Disease. Twin Research and Human Genetics, 1-4. doi: 10.1017/thg.2019.85

Izar, P. (2018). Fundamentos da evolução do comportamento. In M. E, Yamamoto \& J.V Valentova (Orgs.), Manual de psicologia evolucionista (pp. 56-61). Natal, RN/Brazil: EDUFRN.

Kağitçibași, Ç. (1996). Family and human development across countries: A view from the other side. Hillsdale, NJ: Erlbaum

Kağitçibași,, C. (2005). Autonomy and relatedness in cultural context: Implications for self and family. Journal of cross-cultural psychology, 36(4), 403-422.

Kağitçibași,, Ç. (2007) Family, Self, and Human Development Across Cultures: Theory and Applications. Mahwah, NJ: Lawrence Erlbaum Associates.

Keller, H. \& Kartner, J. (2013). Development: The cultural solution of universal development tasks. In M. Gelfand, C.Y Chiu \& Y.Y. Hong (Eds.) Advance in culture and psychology. (pp. 63-116). New York, NY/USA: Oxford University Press.

Keller, H. (2007) Cultures of Infancy. Mahwah, NJ: Lawrence Erlbaum.

Keller, H. (2018). Parenting and socioemotional development in infancy and early childhood. Developmental Review, 50, 31-41.

Klein, B. (2003). Not All Twins are Alike. Westport, CT: Praeger.

Knafo-Noam, A., Vertsbergez, D. \& Israel, S. (2018). Genetic and environmental contributions to children's prosocial behavior: brief review and new evidence from a reanalysis of experimental twin data. Current Opinion in Psychology, 20, p. 60-65. doi: 10.1016/j.copsyc.2017.08.013

Koch, H. L. (1996). Twins and twin relations. Chicago: University of Chicago Press.

LDB (Lei de diretrizes e bases da educação nacional) 2a ed. (2018). Brasília: Senado Federal, Coordenação de Edições Técnicas. Recuperado de: https://www2.senado.leg.br/bdsf/bitstream/handle/id/544283/lei_de_diretrizes_e_bases_2e d.pdf 
Ligthart, L., van Beijsterveldt, C. E. M., Kevenaar, S. T., de Zeeuw, E., van Bergen, E., Bruins, S., Pool, ... \& Boomsma, D. I. (2019). The Netherlands Twin Register: Longitudinal Research Based on Twin and Twin-Family Designs. Twin Research and Human Genetics, 1-14. doi: https://doi.org/10.1017/thg.2019.93

Lytton, H. (1977). Do parents create, or respond to, differences in twins? Developmental Psychology, 13, 456-459. doi: 10.1037/0012-1649.13.5.456

Mark, K. M., Pike, A., Latham, R. M., \& Oliver, B. R. (2017). Using twins to better understand sibling relationships. Behavior genetics, 47(2), 202-214.

Mendelson, M.J., Aboud, F.E., \& Lanthier, R.P. (1994). Kindergartner's relationships with siblings, peers, and friends. Merrill-Palmer Quarterly, 40 (3), 416-435. Recuperado de: https://www.jstor.org/stable/23087353?seq=1

Moilanen, I. (1987). Dominance and submissiveness between twins. II. Consequences for mental health. Acta Geneticae Medicae et Gemellologiae, 36, 257-265. Doi: $10.1017 / \mathrm{S} 0001566000004499$

Murphy, K., Lam, J., Cutler, T., Tyler, J., Calais-Ferreira, L., Li, S., .. \& Hopper, J. L. (2019). Twins Research Australia: A New Paradigm for Driving Twin Research. Twin Research and Human Genetics, 1-8. doi: 10.1017/thg.2019.101

Nilsson, J., Leonard, L., Barazanji, D., \& Simone, R. (2010). Placement of Twins and Multiples in the Classroom: A Brief Survey of School Counselors' Knowledge and Attitudes. Journal of School Counseling, 8(16), 1-18.

Noble, N., Bradley, L., Parr, G., \& Duemer, L. (2017). Fostering twins' identity development: A family issue. The Family Journal, 25(4), 345-350. doi: 10.1177/1066480717731239

Oliva, A.D., Vieira, M.L., Mendes, D.M.F., Martins, G.D.F. (2017). Aspectos biológicos e culturais sobre o desenvolvimento infantil e cuidados parentais. In M.L. Vieira \& A. D. Oliva (Orgs.). Evolução, Cultura e Comportamento humano. Florianópolis, SC/Brazil: Edições do Bosque.

Otta, E., Fernandes, E.S., Acquaviva, T.G., Lucci, T.K., Kiehl, L.C., Varella, M.A., Segal, N.L., \& Valentova, J.V. (2016). Twinning and Multiple Birth Rates According to Maternal Age in the City of São Paulo, Brazil: 2003-2014. Twin Research and Human Genetics, 19, 6, 679-686. doi: 10.1017/thg.2016.75

Otta, E., Fernandes, E.S., Bueno, J., dos Santos, K., Segal, N., Lucci, T., Ferreira, I.F., ... \& Ribeiro, F.J.L. (2019). The University of São Paulo Twin Panel: Current Status and Prospects for Brazilian Twin Studies in Behavioral Research. Twin Research and Human Genetics, 1-8. doi: 10.1017/thg.2019.34

Penninkilampi-Kerola, V., Moilanen, I., \& Kaprio, J. (2005). Co-twin dependence, social interactions, and academic achievement: A population-based study. Journal of Social and Personal Relationships, 22, 4, 519-541, 2005. doi: 10.1177/0265407505054521

Pison, G., \& D'addato, A. V. (2006). Frequency of twin births in developed countries. Twin Research and Human Genetics, 9, 250-259. doi: 10.1375/183242706776382338 
Pison, G., Monden, C., \& Smits, J. (2015). Twinning Rates in Developed Countries: Trends and Explanations. Population and Development Review, 41, 4, 629-649. doi: 10.1111/j.1728-4457.2015.00088.x

Plomin, R., Chipuer, H.M., \& Loehlin, J.C. (1990). Behavioral genetics and personality. In L.A. Pervin (Ed.), Handbook of personality: theory and research. New York, USA: The Guliford Press.

Polderman, T. J. C., Benyamin, B., de Leeuw, C.A., Sullivan, P. F., van Bochoven, A., Visscher, P.M., \& Posthuma, D. (2015). Meta-analysis of the heritability of human traits based on fifty years of twin studies. Nature Genetics, 47, 702-709. doi: 10.1038/ng.3285

Polderman, T. J., Bartels, M., Verhulst, F. C., Huizink, A. C., van Beijsterveldt, C. E., \& Boomsma, D. I. (2010). No effect of classroom sharing on educational achievement in twins: A prospective, longitudinal cohort study. Journal of Epidemiology \& Community Health, 64, 36-40. doi: 10.1136/jech.2009.091629

Pollard, R. (1995). Ethnic comparison of twinning rates in California. Human Biology, 67, 21931. Recuperado de: https://www.jstor.org/stable/41465442?seq=1

Preedy, P. (1999). Meeting The Educational Needs Of Preschool And Primary Aged Twins And Higher Multiples. In: A.C. SANDBANK (Ed.), Twin and Triplet Psychology (pp. 7099). Londres/England: Routledge.

Resende, B.D., Ripardo, R. \& Oliva, A.D. (2018). Psicologia Evolucionista e Algumas Contribuições para o Comportamento Humano. In M. E. Yamamoto \& J.V. Valentova (Orgs.), Manual de psicologia evolucionista (pp. 56-61). Natal, RN/Brazil: EDUFRN.

Reynolds, M. A., Schieve, L.A., Martin, J.A., Jeng, G., \& Macaluso, M. et al. (2003). Trends in multiple births conceived using assisted reproductive technology, United States, 19972000. Pediatrics, 111, 1159-1162. Recuperado de: https://www.ncbi.nlm.nih.gov/pubmed/12728130

Robin, M., Corroyer, D., \& Casati, I. (1996). Childcare patterns of mothers of twins during the first year. Journal of Child Psychology and Psychiatry, 37, 453-460. doi: 10.1111/j.14697610.1996.tb01426.x

Rodrigues, G. A. (2014). Percepções de gêmeos acerca de estudar ou não na mesma turma (Trabalho de Conclusão de Curso, Faculdade de Educação da Universidade Federal do Rio Grande do Sul, Porto Alegre). Recuperado de: https://lume.ufrgs.br/bitstream/handle/10183/115812/000963592.pdf?sequence=1\&isAllo wed $=\mathrm{y}$

Rosen, S. I. (1972). Twin gorilla fetuses. Folia Primatologica, 17(1-2), 132-141.

Rutter, M., \& Redshaw, J. (1991). Annotation: Growing up as a twin: twin-singleton differences in psychological development. Journal of Child Psychology and Psychiatry, and Allied Disciplines, 32 (6), 885-895. doi: 10.1111/j.14697610.1991.tb01916.x

Sandbank, A. C. (1999). Personality, identity and family relationships. In A.C Sandbank (Ed.), Twin and triplet psychology: A professional guide to working with multiples (pp.167-184). Londres/England: Routledge.. 
Saudino, K. J., Cherny, S. S., \& Plomin, R. (2000). Parent ratings of temperament in twins: explaining the 'too low'DZ correlations. Twin Research and Human Genetics, 3(4), 224233. doi: 10.1375/twin.3.4.224

Sear, R., Mace, R., Shanley, D., \& Mcgregor, M. (2001). The Fitness of twin mothers: evidence from rural Gambia. Journal of Evolutionary Biology, 14 (3), 433-443. doi: 10.1046/j.14209101.2001.00287.x

Segal, H., \& Knafo-Noam, A. (2019). The Twin Relationship Questionnaire: Testing a FiveFactor Model From Early to Middle Childhood. European Journal of Psychological Assessment. doi: 10.1027/1015-5759/a000504

Segal, H., Knafo-Noam, A. (2018). Twin Rivalry in Childhood. In S. L. Hart \& A. Jones (Eds.), The Psychology of Rivalry (pp. 112-129). New York, USA: Nova Science Publishers, Inc.

Segal, N. L. (1984). Cooperation, competition, and altruism within twin sets: A reappraisal. Ethology and Sociobiology, 5, 163-177. doi: 10.1016/0162-3095(84)90021-9

Segal, N. L. (2017). Twin Mythconceptions: False Beliefs, Fables, and Facts about Twins. Cambridge, Massachusetts: Academic Press.

Segal, N. L., \& Hershberger, S. L. (1999). Cooperation and competition in adolescent twins: Findings from a prisoner's dilemma game. Evolution and Human Behavior, 20, 29-51. doi: 10.1016/S1090-5138(98)00039-7

Segal, N. L., \& Russell, J. M. (1992). Twins in the classroom: school policy issues and recommendations. Jornal of Educational and Psychological Consultation, 3, 69- 84. doi: 10.1207/s1532768xjepc0301_5

Segal, N. L., Blozis, S. A., Sussman, L. (2001). When twins lose twins: Implications for Theory and Practice. Twin Research and Human Genetics, 4 (3).

Segal, N.L. (1990). Importance of Twin Studies for Individual Differences Research. Journal of Counseling and Development, 68. doi: 10.1002/j.1556-6676.1990.tb01425.x

Segal, N.L. (1999). Entwined Lives: Twins and What They Tell Us About Human Behavior. Nova York: Penguin Putnam Inc.

Seidl-de-Moura, M. L., Lordelo, E. R., Vieira, M. L., Piccinini, C. A., Siqueira, J. O., Magalhães, C. M. C, Pontes, F. A. R., ... \& Rimoli, A. Brazilian mothers' socialization goals: Intracultural differences in seven Brazilian cities. International Journal of Behavioral Development, 32(6), 465-472, 2008. doi: 10.1177/0165025408093666

Sharpsteen, D. J., \& Kirkpatrick, L. A. (1997). Romantic Jealousy and Adult Romantic Attachment. Journal of Personality and social Psychology, 72 (3), 627- 640. doi: 10.1037//0022-3514.72.3.627

Sharrow, D. J., \& Anderson, J. J. (2016). A twin protection effect? Explaining twin survival advantages with a two-process mortality model. PloS one, 11(5). doi: 10.1371/journal.pone.0154774

Smits, J., \& Monden, C. (2009). Twinning across the Developing World. Plos One, 6 (9). doi: 10.1371/journal.pone.0025239 
Staton, S., Thorpe, K., Thompson, C., \& Danby, S. (2012). To separate or not to separate? Parental decision-making regarding the separation of twins in the early years of schooling. Journal of Early Childhood Research, 10, 196-208. doi: 10.1177/1476718X11430076

Sugiyama, Y., Kurita, H., Matsui, T., \& Shimomura, T. (2011). Twinning frequency of Japanese macaques (Macaca fuscata) at Takasakiyama. Primates, 52(1), 19-23.

Tancredy, C. M., \& Fraley, R. C. (2006). The nature of adult Twin Relationship: An Attachment - Theoretical Perspective. Journal of Personality and social Psychology, 90, 78-93. doi: 10.1037/0022-3514.90.1.78

Tellegen, A., Lykken, D. T., Bouchard, T. J., Wilcox, K. J., Segal, N. L., \& Rich, S. (1988). Personality similarity in twins reared apart and together. Journal of personality and social psychology, 54(6), 1031. doi: 10.1037/0022-3514.54.6.1031

Thorpe, K., \& Danby, S. (2006) Compromised or competent: Analysing twin children's social worlds. Twin Research and Human Genetics, 9(1), 90-94. Doi: 10.1375/twin.9.1.90

Thorpe, K., Golding, J., Macgilivray, I., \& Greenwood, R. (1991). Comparison of prevalence of depression in mothers of twins and mothers of singletons. BMJ, 302 (6781), 875-878. doi: 10.1136/bmj.302.6781.875

Tinbergen, N. (1963). On aims and methods of ethology. Zeitschrift für tierpsychologie, 20 (4), 410-433.

Triandis, H.C. (1989). The self and social behavior in different cultural contexts. Psychological Review, 96, 506-520. doi: 10.1037/0033-295X.96.3.506

Trivers, R. L. (1972). Parental investment and sexual selection. In B. Campbell (Eds.), Sexual Selection \& the Descent of Man (pp. 136-179). Chicago: Aldine

Tully, L. A., Moffitt, T.E., Caspi, A., Taylor, A., Kiernan, H., \& Andreou, P. (2004). What effect does classroom separation have on twins Behavior, Progress at school, and reading abilities? Twin Research, 7 (2), 115-124, 2004. doi: 10.1375/136905204323016087

van Leeuwen, M., van den Berg, S. M., van Beijsterveldt, T. C. E. M., \& Boomsma, D. I. (2005). Effects of twin separation in primary school. Twin Research Human Genetic, 9, 38491. doi: $10.1375 /$ twin.8.4.384

Varella, M. A. C, Fernandes, E. S, Arantes, J., Acquaviva, T., Lucci, T., Hsu, R., David, V., Bussab, V., Valentova, J.V, Segal, N., \& Otta, E. (2018). Twinning as an evolved agedependent physiological mechanism: Evidence from large Brazilian samples. In J. Elito Jr. (Ed.), Multiple pregnancies. New challenges (pp. 28-46). IntechOpen. Recuperado de: https://www.intechopen.com/books/multiple-pregnancy-new-challenges/twinning-as-anevolved-age-dependent-physiological-mechanism-evidence-from-large-brazilian-samples

Varella, M. A. C. (2018). Mal-entendidos sobre a Psicologia Evolucionista. Fundamentos da evolução do comportamento. In M. E. Yamamoto \& J.V. Valentova (Orgs.), Manual de psicologia evolucionista. Natal, RN: EDUFRN.

Verdugo, M. A., \& Sabeh, E.N. (2002). Evaluación de la percepción de calidad de vida em la infância. Psicothema, 14 (1), 86-91. Recuperado de: http://www.psicothema.com/psicothema.asp?id=690 
Volling, B.L., \& Blandon, A.Y. (2003). Positive Indicators of Sibling Relationship Quality: Psychometric Analyses of The Sibling Inventory of Behavior (SIB). In University of Michigan For Indicators of Positive Development Conference (pp. 12-13). Michigan, USA.

Vukasović, T., \& Bratko, D. (2015). Heritability of personality: a meta-analysis of behavior genetic studies. Psychological bulletin, 141(4), 769. doi: 10.1037/bul0000017

Westphal, J. P., Vieira, V., Vieira, M. L., \& Prado, A. B. (2010). O que mães pensam sobre seus filhos em três regiões distintas do Estado de Santa Catarina. Psicologia Argumentativa, 28 (62), 235-246. doi: 10.7213/rpa.v28i62.19897

White, E. K., Garon-Carrier, G., Tosto, M. G., Malykh, S. B., Li, X., Kiddle, B., ... \& Vitaro, F. (2018). Twin classroom dilemma: To study together or separately? Developmental psychology, 54(7), 1244. doi: 10.1037/dev0000519

Woodward, J. (1998). The lone twin: Understanding twin bereavement and loss. London: Free Association Books.

Yamamoto, M. E., Alencar, A. I., \& Lacerda, A.R. (2018). Competição e Cooperação. In M. E. Yamamoto \& J.V. Valentova (Orgs.), Manual de psicologia evolucionista (pp. 56-61). Natal, RN: EDUFRN.

Yoon-Mi-Hur, Y., Jeong, H., Kang, M. C., Ajose, F., Kim, J.W., Beck, J.J., ... \& Bates, T. (2019). The Nigerian Twin and Sibling Registry: An Update. Twin Research and Human Genetics, 1-4. doi: 10.1017/thg.2019.110 


\section{APÊNDICE A - Questionário de zigosidade adaptado para responsáveis de gêmeos baseado em Christiansen et al. (2003)}

1. Seus/suas filhos/as gêmeos/as:

a. Não são muito parecidos/as fisicamente

b. São parecidos/as fisicamente quanto dois/duas irmãos/irmãs que não são gêmeos/as

c. São tão parecidos/as físicamente como duas gotas de água, ou como diz o ditado popular "a cara de um, focinho do outro"

2. Na escola, é difícil para os professores e amigos dos/as gêmeos/as distinguirem um/uma do/a outro/a?

a. $\mathrm{Sim}$

b. Não

3. É difícil para sua família ou amigos diferenciarem os/as gêmeos/as um/a do/a outro/a?

a. $\operatorname{Sim}$

b. Não

4. Os/as gêmeos/as têm a mesma cor de olhos e a mesma cor de cabelo?

a. $\operatorname{Sim}$

b. Não

\section{Autorrelato Zigosidade}

6. Você sabe se seus/suas filhos/as são gêmeos/as idênticos/as?

a. Com certeza são idênticos (Monozigóticos)

b. Com certeza não são idênticos (Dizigóticos ou fraternos)

c. Não sei/não tenho certeza 


\section{APÊNDICE B - Questionário de gêmeos na escola para responsáveis}

\section{Sessão 1}

1. Em qual cidade seus/suas gêmeos/as estudam atualmente?

2. Em qual estado seus/suas gêmeos/as estudam atualmente?

3. Em qual série estão seus/suas gêmeo/as?

a. Creche

b. Pré-escola

c. $1^{\circ}$ ano do fundamental I

d. $2^{\circ}$ ano do fundamental I

e. $3^{\circ}$ ano do fundamental I

f. $4^{\circ}$ ano do fundamental I

g. $5^{\circ}$ ano do fundamental II

h. $6^{\circ}$ ano do fundamental II

i. $7^{\circ}$ ano do fundamental II

j. $8^{\circ}$ ano do fundamental II

k. $9^{\circ}$ ano do fundamental II

4. A escola em que seus gêmeos estudam é:

a. Particular

b. Pública

\section{Sessão 2: Sobre os seus gêmeos estudarem juntos ou separados}

5. Seus gêmeos:

a. Sempre estudaram juntos (Encaminhado para sessão 4)

b. Sempre estudaram separados (Encaminhado para sessão 3)

c. Estudavam juntos, mas hoje estudam separados (Encaminhado para sessão 3 )

d. Estudavam separados, mas hoje estudam juntos (Encaminhado para sessão 4)

6. Esta foi uma decisão dos responsáveis ou da escola?

a. Decisão feita pelos responsáveis

b. Decisão feita pela escola

c. Decisão conjunta entre responsáveis e escola

d. Não sei informar

e. Outro

7. Quais foram os motivos para esta decisão?

8. Você está feliz com esta decisão?

a. Sim

b. Não

c. Indiferente

9. A escola em que seus gêmeos estudam: 
a. Insiste que gêmeos devem estudar na mesma sala

b. Insiste que gêmeos devem estudar em salas distintas

c. É bastante flexível e aberta a opinião dos pais

d. Não sei

e. Outros:

\section{Sessão 3: Sobre gêmeos estudarem em salas distintas}

Tendo a escala de 1 a 7 como base, indique seu posicionamento em relação as perguntas abaixo.

10. Quanto você considera que os/as gêmeos/as gostam de estudar separados/as?

Ancoras: 1. Detestam totalmente e 7. Gostam totalmente

11. Quanto você considera que estudar em salas diferentes contribui para o desempenho escolar dos/das gêmeos/as?

Ancoras: 1. Não contribui nada e 7. Contribui totalmente

12. Quanto você considera que estudar em salas diferentes contribui para a sociabilidade dos/as gêmeos/as?

Ancoras: 1. Não contribui nada e 7. Contribui totalmente

13. Quanto você considera que estudar em salas diferentes contribui para a individualidade dos/as gêmeos/as?

Ancoras: 1. Não contribui nada e 7. Contribui totalmente

14. Quanto você considera que estudar em salas diferentes contribui para o desenvolvimento da personalidade dos/as gêmeos/as?

Ancoras: 1. Não contribui nada e 7. Contribui totalmente

15. Quanto você considera que estudar em salas diferentes contribui para o bemestar dos/as gêmeos/as?

Ancoras: 1. Não contribui nada e 7. Contribui totalmente

16. Quanto você considera que estudar em salas diferentes contribui para uma boa relação entre os/as gêmeos/as?

Ancoras: 1. Não contribui nada e 7. Contribui totalmente

17. Quanto você gosta que seus/suas gêmeos/as estudem separados/as?

Ancoras: 1. Detesto totalmente e 7. Gosto totalmente

18. Se você quiser compartilhar outros pontos positivos e negativos sobre gêmeos/as estudarem separados/as ou quiser fazer alguma observação sobre o tema, por favor, escreva abaixo.

\section{Sessão 4: Sobre gêmeos estudarem na mesma sala}

Tendo a escala de 1 a 7 como base, indique seu posicionamento em relação as perguntas abaixo. 
19. Quanto você considera que os/as gêmeos/as gostam de estudar juntos/as?

Ancoras: 1. Detestam totalmente e 7. Gostam totalmente

20. Quanto você considera que estudar na mesma sala contribui para o desempenho escolar dos/das gêmeos/as?

Ancoras: 1. Não contribui nada e 7. Contribui totalmente

21. Quanto você considera que estudar na mesma sala contribui para a sociabilidade dos/as gêmeos/as?

Ancoras: 1. Não contribui nada e 7. Contribui totalmente

22. Quanto você considera que estudar na mesma sala contribui para a individualidade dos/as gêmeos/as?

Ancoras: 1. Não contribui nada e 7. Contribui totalmente

23. Quanto você considera que estudar na mesma sala contribui para o desenvolvimento da personalidade dos/as gêmeos/as?

Ancoras: 1. Não contribui nada e 7. Contribui totalmente

24. Quanto você considera que estudar na mesma sala contribui para o bem-estar dos/as gêmeos/as?

Ancoras: 1. Não contribui nada e 7. Contribui totalmente

25. Quanto você considera que estudar na mesma sala contribui para uma boa relação entre os/as gêmeos/as?

Ancoras: 1. Não contribui nada e 7. Contribui totalmente

26. Quanto você gosta que seus/suas gêmeos/as estudem juntos/as?

Ancoras: 1. Detesto totalmente e 7. Gosto totalmente

27. Se você quiser compartilhar outros pontos positivos e negativos sobre gêmeos/as estudarem juntos/as ou quiser fazer alguma observação sobre o tema, por favor, escreva abaixo.

\section{Sessão 5: De forma geral}

28. Na sua opinião, gêmeos devem:

a. Estudar na mesma sala

b. Estudar em salas diferentes

c. Indiferente

d. Depende

29. Explique os motivos para sua opinião.

30. O quanto você acha que o sexo dos gêmeos influencia na decisão de separá-los ou não em salas distintas?

Ancora: 1. Não tem influência nenhuma e 7. Influencia totalmente 
31. O quanto você acha que a idade dos gêmeos influencia na decisão de separálos ou não em salas distintas?

Ancora: 1. Não tem influência nenhuma e 7. Influencia totalmente

32. O quanto você acha que o sexo dos gêmeos influencia na decisão de separá-los ou não em salas distintas?

Ancora: 1. Não tem influência nenhuma e 7. Influencia totalmente

33. O quanto você acha que a semelhança dos gêmeos influencia na decisão de separá-los ou não em salas distintas?

Ancora: 1. Não tem influência nenhuma e 7. Influencia totalmente

34. O quanto você acha que a relação dos gêmeos influencia na decisão de separálos ou não em salas distintas?

Ancora: 1. Não tem influência nenhuma e 7. Influencia totalmente

35. Na sua opinião, existe algum outro fator que influencia na decisão de separar ou não os gêmeos em salas distintas? 


\section{APÊNDICE C - Twin Relationship Questionnaire criado por Fortuna, Goldner e Knafo (2010), traduzido e adaptado para o português}

Leia cada afirmativa e responda a que melhor se aplica ao comportamento do gêmeo. Para isso, você deve assinalar um dos cinco números apresentados ao lado de cada afirmativa. Um (1) significa que o comportamento citado é NADA CARACTERÍSTICO do gêmeo e cinco (5) significa que o comportamento é MUITO CARACTERÍSTICO do gêmeo. Os valores intermediários indicam gradações entre esses extremos, isto é, à medida que os valores aumentam, aumenta a chance de o gêmeo apresentar o comportamento ${ }^{10}$.

\begin{tabular}{|c|c|c|c|c|c|}
\hline Afirmações & \multicolumn{5}{|c|}{ Escala de 1 a 5} \\
\hline O Gêmeo 1 gosta de estar com o(a) irmão(ã) gêmeo(a) & 1 & 2 & 3 & 4 & 5 \\
\hline 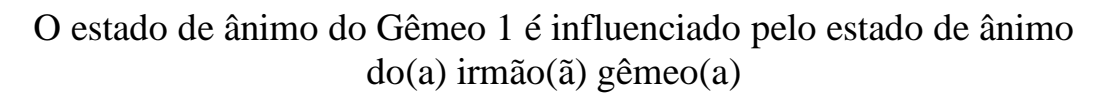 & 1 & 2 & 3 & 4 & 5 \\
\hline $\begin{array}{l}\text { O Gêmeo } 1 \text { fica infeliz quando a outra pessoa responsável por ele passa } \\
\text { tempo fazendo coisas com o(a) irmão(ã) gêmeo(a) }\end{array}$ & 1 & 2 & 3 & 4 & 5 \\
\hline $\begin{array}{l}\text { O Gêmeo } 1 \text { sente falta do(da) irmão(ã) gêmeo(a) quando não estão } \\
\text { juntos }\end{array}$ & 1 & 2 & 3 & 4 & 5 \\
\hline O Gêmeo 1 gosta de dizer para o(a) irmão(ã) gêmeo(a) o que fazer & 1 & 2 & 3 & 4 & 5 \\
\hline O Gêmeo 1 fere os sentimentos do(a) irmão(ã) gêmeo(a) & 1 & 2 & 3 & 4 & 5 \\
\hline $\begin{array}{l}\text { \O Gêmeo 1, em geral, fica zangado quando é separado(a) do(a) } \\
\text { irmão(ã) gêmeo(a) }\end{array}$ & 1 & 2 & 3 & 4 & 5 \\
\hline O Gêmeo 1 reclama e discute com o(a) irmão(ã) gêmeo(a) & 1 & 2 & 3 & 4 & 5 \\
\hline $\begin{array}{l}\text { O Gêmeo 1, em geral, decide pelo(a) irmão(ã) gêmeo(a) sobre o que } \\
\text { vão brincar }\end{array}$ & 1 & 2 & 3 & 4 & 5 \\
\hline O Gêmeo 1 fica zangado(a) com o(a) irmão(ã) gêmeo(a) & 1 & 2 & 3 & 4 & 5 \\
\hline O Gêmeo 1 se interessa pelo(a) irmão(ã) gêmeo(a) & 1 & 2 & 3 & 4 & 5 \\
\hline O Gêmeo 1 é muito competitivo(a) em relação ao(à) irmão(ã) gêmeo(a) & 1 & 2 & 3 & 4 & 5 \\
\hline $\begin{array}{l}\text { O Gêmeo } 1 \text { é afetado quando o(a) irmão(ã) gêmeo(a) fica doente ou } \\
\text { chateado(a) }\end{array}$ & 1 & 2 & 3 & 4 & 5 \\
\hline $\begin{array}{l}\text { O Gêmeo } 1 \text { luta fisicamente com o(a) irmão(ã) gêmeo(a) (não apenas } \\
\text { por divertimento) }\end{array}$ & 1 & 2 & 3 & 4 & 5 \\
\hline O Gêmeo 1 quer brincar com o(a) irmão(ã) gêmeo(a) & 1 & 2 & 3 & 4 & 5 \\
\hline O Gêmeo 1 , muitas vezes, tende a ser o(a) gêmeo(a) dominante & 1 & 2 & 3 & 4 & 5 \\
\hline O Gêmeo 1 provoca ou irrita o(a) irmão(ã) gêmeo(a) & 1 & 2 & 3 & 4 & 5 \\
\hline $\begin{array}{l}\text { O Gêmeo 1, em geral, compreende o(a) irmão(ã) gêmeo(a) da melhor } \\
\text { forma possível }\end{array}$ & 1 & 2 & 3 & 4 & 5 \\
\hline $\begin{array}{c}\text { O Gêmeo } 1 \text { acusa o(a) irmão(ã) gêmeo(a) quando alguma coisa sai } \\
\text { errada }\end{array}$ & 1 & 2 & 3 & 4 & 5 \\
\hline $\begin{array}{l}\text { Gêmeo } 1 \text { fica chateado(a) quando é separado(a) do(a) irmão(ã) } \\
\text { gêmeo(a) }\end{array}$ & 1 & 2 & 3 & 4 & 5 \\
\hline $\begin{array}{c}\text { O Gêmeo } 1 \text { fica infeliz ou ciumento(a) quando você faz coisas com o } \\
\text { irmão(ã) gêmeo(a). }\end{array}$ & 1 & 2 & 3 & 4 & 5 \\
\hline O Gêmeo 1 diverte-se muito com o(a) irmão(ã) gêmeo(a) & 1 & 2 & 3 & 4 & 5 \\
\hline
\end{tabular}

10 O mesmo questionário será respondido para o Gêmeo 2 
ANEXO A - Parecer Consubstanciado do CEP (Gêmeos na escola)

\section{USP- INSTITUTO DE \\ PSICOLOGIA DA \\ UNIVERSIDADE DE SÃO}

\section{PARECER CONSUBSTANCIADO DO CEP}

\section{DADOS DO PROJETO DE PESQUISA}

Título da Pesquisa: Gêmeos na escola: Perspectiva de pais, gêmeos e professores

Pesquisador: Emma Otta

Área Temática:

Versão: 1

CAAE: 86600718.9 .0000 .5561

Instituição Proponente: UNIVERSIDADE DE SAO PAULO

Patrocinador Principal: UNIVERSIDADE DE SAO PAULO

\section{DADOS DO PARECER}

Número do Parecer: 2.606 .770

Apresentação do Projeto:

Mães, pais e professores de crianças gêmeas monozigóticas (MZ) e dizigóticas (DZ), em início de escolarização (3-10 anos), irão responder um questionário sobre separação de gêmeos na escola, baseado no instrumento desenvolvido por Nancy Segal e Jean Russell (1992). Além disso, gêmeos irão responder a um questionário simples sobre serem separados ou mantidos na mesma sala de aula com seus irmãos. Iremos comparar as respostas de cada grupo e verificar se há diferenças entre as respostas. Além disso, as mães e os pais trarão, eventualmente, vídeos, na medida em que disponham, para ilustrar reações dos gêmeos à decisão de separação.

Objetivo da Pesquisa:

Realizar um survey com mães, pais e professores de gêmeos em início de escolarização (3-10 anos), em relação a separar gêmeos em classes diferentes ou mantê-los na mesma classe, e as razões para isto. Além de verificar de que modo os gêmeos reagem frente a essa decisão.

1) Coletar informações por meio de vídeos e relatos dos pais das reações de irmãos gêmeos frente a situações de separação escolar.

2) Aplicar o questionário em pais e mães de gêmeos. Verificar se há diferença entre as respostas de pais e de mães;

3) Verificar se há diferença entre as respostas de pais e mães de gêmeos monozigóticos e dizigóticos;

4) Verificar se há diferença de respostas e reações de gêmeos monozigóticos e dizigóticos frente a

Endereço: Av. Prof. Mello Moraes,1721 - Bl. "G" sala 27

Bairro: Cidade Universitária CEP: $05.508-030$

UF: SP Município: SAO PAULO

Telefone: (11)3091-4182

E-mail: ceph.ip@usp.br 


\section{USP- INSTITUTO DE PSICOLOGIA DA UNIVERSIDADE DE SÃO}

Continuação do Parecer: 2.606 .770

separação escolar;

5) Comparar e verificar se há diferença de respostas e crenças de pais, mães e professores frente ao tema de separação de gêmeos na escola.

Avaliação dos Riscos e Benefícios:

Conforme a pesquisadora,

"Riscos:

Os questionários serão preenchidos pelos pais, mães e professores por meio de um questionário online. Caso haja algum inconveniente eles serão informados que poderão interromper a pesquisa a qualquer momento. Os pais serão convidados a enviar relatos e vídeos de situações que envolvem o assunto de separação de gêmeos na escola.

Benefícios:

Os participantes irão contribuir para o desenvolvimento de pesquisa sobre gêmeos no Brasil, especificamente sobre a questão do impacto da separação de gêmeos no ingresso escolar. $\bigcirc$ grupo de pesquisa tem interesse em divulgar os resultados em revistas científicas e não científicas, pois este trabalho pretende ser um importante instrumento de consulta e reflexão para pesquisadores, professores e pais."

Este CEPH aponta para o fato de que, na Resolução 466/12, toda pesquisa com seres humanos envolve algum tipo de risco, ainda que mínimo.

\section{Comentários e Considerações sobre a Pesquisa:}

Cronograma de Execução: Coleta de dados 20/04/2018 01/11/2018

$\mathrm{N}^{\circ}$ de participantes da pesquisa: 300

ID Grupo $N^{\circ}$ de Indivíduos Intervenções a serem realizadas

- Gêmeos 50 De 3 a 10 anos, irão responder a um questionário sobre separação escolar e se possível

filmados pelos pais, a fim de observar a reação deles frente ao tema de

separação escolar

- Professores 50 Irão responder a um questionário sobre separação de gêmeos na escola

- Pais 100 Irão responder a um questionário sobre zigosidade e separação de gêmeos na escola

- Mães 100 Irão responder a um questionário sobre zigosidade e separação de gêmeos na escola

Irão participar da pesquisa 100 pais e 100 mães de gêmeos ou múltiplos (N=200), 50

Endereço: Av. Prof. Mello Moraes, 1721 - BI. "G" sala 27

Bairro: Cidade Universitária CEP: $05.508-030$

UF: SP Município: SAO PAULO

Telefone: (11)3091-4182

E-mail: ceph.ip@usp.br 


\section{USP- INSTITUTO DE PSICOLOGIA DA UNIVERSIDADE DE SÃO}

Continuação do Parecer: 2.606 .770

gêmeos/múltiplos e 50 professores. Eles serão convidados a participar por meio da divulgação da pesquisa por e-mail e em grupos de pais de gêmeos na rede social como por exemplo: Facebook, Instagram, e pelo aplicativo WhatsApp no celular. A pesquisa será feita online.

Instrumentos - Serão utilizados os seguintes instrumentos:

1) Para a avaliação da zigosidade dos irmãos, será usada uma adaptação da escala criada pelo Registro de Gêmeos da Dinamarca de Christiansen et al. (2003).

2) Para o survey feito com as mães, pais e professores será utilizado o questionário de Segal e Russel (1992) com as devidas adaptações feitas para cada grupo.

\section{Considerações sobre os Termos de apresentação obrigatória:}

No TCLE consta:

"5. Há algum risco ou custo em participar?

Não há risco algum. Se você sentir algum desconforto ou incômodo com alguma parte da pesquisa, você pode interromper sua participação a qualquer momento e seus dados não serão analisados."

Conclusões ou Pendências e Lista de Inadequações:

O projeto está aprovado.

Considerações Finais a critério do CEP:

No sentido de facilitar e agilizar a apreciação da resposta a ser apresentada pelo(a) pesquisador(a) responsável à(s) pendência(s) apontadas neste parecer consubstanciado, esta resposta deverá ser dada da seguinte forma:

- nos novos documentos anexados sejam destacados em vermelho as modificações realizadas;

- as respostas e modificações realizadas devem ser sumariadas em uma carta ao $\mathrm{CEPH}$, anexada à Plataforma Brasil, abordando item a item das recomendações;

- não deixar de consultar todos os itens constantes à página do CEPH-IPUSP: http://www.ip.usp.br/portal/index.php?option=com_content\&view=article\&id=312\&ltemid=283\&lang=pt

Este parecer foi elaborado baseado nos documentos abaixo relacionados:

\begin{tabular}{|l|l|c|c|c|}
\hline \multicolumn{1}{|c|}{ Tipo Documento } & \multicolumn{1}{|c|}{ Arquivo } & Postagem & Autor & Situação \\
\hline Informações Básicas & PB_INFORMAÇÕES_BÁSICAS_DO_P & $26 / 03 / 2018$ & & Aceito \\
do Projeto & ROJETO 1070396.pdf & $13: 18: 55$ & & Aceito \\
\hline Informações Básicas & PB_INFORMAÇÕES_BÁSICAS_DO_P & $26 / 03 / 2018$ & & \\
do Projeto & ROJETO 1070396.pdf & $13: 08: 26$ & & \\
\hline
\end{tabular}

Endereço: Av. Prof. Mello Moraes,1721 - Bl. "G" sala 27

Bairro: Cidade Universitária CEP: $05.508-030$

UF: SP Município: SAO PAULO

Telefone: (11)3091-4182

E-mail: ceph.ip@usp.br 


\section{USP- INSTITUTO DE \\ PSICOLOGIA DA UNIVERSIDADE DE SÃO}

Continuação do Parecer: 2.606.770

\begin{tabular}{|c|c|c|c|c|}
\hline $\begin{array}{l}\text { Declaração de } \\
\text { Pesquisadores }\end{array}$ & $\begin{array}{l}\text { declaracao_pesquisador_Gemeos_na_e } \\
\text { scola.pdf }\end{array}$ & $\begin{array}{c}26 / 03 / 2018 \\
13: 07: 47 \\
\end{array}$ & Emma Otta & Aceito \\
\hline Folha de Rosto & Folha_Rosto_Gemeos_na_Escola.pdf & $\begin{array}{c}26 / 03 / 2018 \\
13: 05: 42\end{array}$ & Emma Otta & Aceito \\
\hline $\begin{array}{l}\text { Projeto Detalhado / } \\
\text { Brochura } \\
\text { Investigador }\end{array}$ & $\begin{array}{l}\text { Projeto_de_Pesquisa_Gemeos_na_Esc } \\
\text { ola.pdf }\end{array}$ & $\begin{array}{c}02 / 02 / 2018 \\
19: 29: 10\end{array}$ & Emma Otta & Aceito \\
\hline $\begin{array}{l}\text { TCLE / Termos de } \\
\text { Assentimento / } \\
\text { Justificativa de } \\
\text { Ausência } \\
\end{array}$ & TALE_Gemeos_na_Escola.pdf & $\begin{array}{l}02 / 02 / 2018 \\
19: 28: 17\end{array}$ & Emma Otta & Aceito \\
\hline $\begin{array}{l}\text { TCLE / Termos de } \\
\text { Assentimento / } \\
\text { Justificativa de } \\
\text { Ausência }\end{array}$ & TCLE_Gemeos_na_Escola.pdf & $\begin{array}{c}02 / 02 / 2018 \\
19: 27: 46\end{array}$ & Emma Otta & Aceito \\
\hline $\begin{array}{l}\text { Declaração de } \\
\text { Instituição e } \\
\text { Infraestrutura }\end{array}$ & Infraestrutura_Gemeos_na_Escola.pdf & $\begin{array}{c}02 / 02 / 2018 \\
19: 12: 59\end{array}$ & Emma Otta & Aceito \\
\hline
\end{tabular}

Situação do Parecer:

Aprovado

Necessita Apreciação da CONEP:

Não

SAO PAULO, 18 de Abril de 2018

Assinado por:

Helena Rinaldi Rosa

(Coordenador)

Endereço: Av. Prof. Mello Moraes, 1721 - BI. "G" sala 27

Bairro: Cidade Universitária

CEP: $05.508-030$

Telefone: (11)3091-4182

E-mail: ceph.ip@usp.br 


\section{ANEXO B - Parecer consubstanciado do CEP (Relacionamento entre gêmeos e reações à separação)}

\section{USP- INSTITUTO DE PSICOLOGIA DA UNIVERSIDADE DE SÃO}

\section{PARECER CONSUBSTANCIADO DO CEP}

\section{DADOS DO PROJETO DE PESQUISA}

Título da Pesquisa: Relacionamento entre Gêmeos e reações à separação

Pesquisador: Emma Otta

Área Temática:

Versão: 1

CAAE: 79708517.8 .0000 .5561

Instituição Proponente:UNIVERSIDADE DE SAO PAULO

Patrocinador Principal: UNIVERSIDADE DE SAO PAULO

\section{DADOS DO PARECER}

Número do Parecer: 2.380 .097

Apresentação do Projeto:

Mães e pais de crianças gêmeas monozigóticas (MZ) e dizigóticas (DZ), na primeira infância, irão responder o Twin Relationship Questionnaire (TRQ) desenvolvido por Fortuna, Goldner e Knafo (2010). Iremos verificar se a análise fatorial da escala irá reproduzir a estrutura de dois domínios encontrada no Longitudinal Israeli Study of Twins (LIST): proximidade/dependência versus conflito/rivalidade. Além disso, as mães e os pais trarão

relatos e, eventualmente, também vídeos, na medida em que disponham, para ilustrar reações à separação e ao reencontro dos irmãos gêmeos.

Objetivo da Pesquisa:

Verificar se as reações de irmãos gêmeos frente a situações de separação cotidiana e frente à separação escolar diferem em relação ao tipo de gemelaridade (zigosidade) e tipo de relacionamento entre eles.

\section{Avaliação dos Riscos e Benefícios:}

Conforme a pesquisadora,

Riscos:

"O questionário sobre relacionamento entre os irmãos gêmeos será preenchido pelos pais e mães por meio de um questionário online. Caso haja algum inconveniente os pais serão informados que poderão interromper a pesquisa a qualquer momento. Com relação às situações de separação entre os irmãos gêmeos, os pais serão convidados a enviar relatos e vídeos de situações que

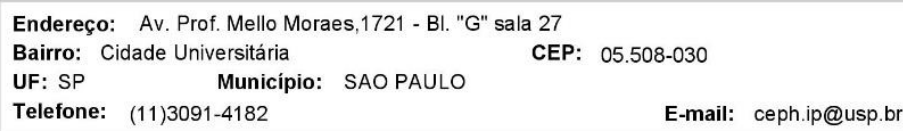




\section{USP- INSTITUTO DE PSICOLOGIA DA UNIVERSIDADE DE SÃO}

Continuação do Parecer: $2,380.097$

acontecem cotidianamente e, portanto, não haverá intervenção dos pesquisadores.

Benefícios:

Os participantes irão contribuir para o desenvolvimento de pesquisa sobre gêmeos no Brasil, especificamente sobre a questão sobre o impacto da separação de gêmeos no ingresso escolar e outros momentos da vida. O grupo de pesquisa tem interesse em divulgar os resultados em revistas científicas e não científicas para que os resultados possam ser conhecidos pela população em geral."

\section{Comentários e Considerações sobre a Pesquisa:}

Critério de Inclusão:

Ser pai ou mãe de gêmeos ou múltiplos monozigóticos ou dizigóticos, com filhos em idade entre 1 e 6 anos. Critério de Exclusão:

Ser menor de idade, não ser pai/mãe de gêmeos ou múltiplos.

\section{Considerações sobre os Termos de apresentação obrigatória:}

No TCLE, item 5. "Há algum risco ou custo em participar?

Não há risco algum. Se você sentir algum desconforto ou incômodo com alguma parte da pesquisa, você pode interromper sua participação a qualquer momento e seus dados não serão analisados. Não existe qualquer custo associado à sua participação. Não irá receber qualquer pagamento por fazer parte neste estudo."

Conforme a Resolução 466/12, toda pesquisa com seres humanos envolve riscos, ainda que mínimos, assim a primeira frase deve ser retirada.

Conclusões ou Pendências e Lista de Inadequações:

O projeto está aprovado.

Considerações Finais a critério do CEP:

Se o projeto prevê aplicação de TCLE, todas as páginas do documento deverão ser rubricadas pelo pesquisador e pelo voluntário e a última página assinada por ambos, conforme Carta Circular no 003/2011 da CONEP/CNS.

Salientamos que o pesquisador deve desenvolver a pesquisa conforme delineada no protocolo aprovado. Eventuais modificações ou emendas ao protocolo devem ser apresentadas ao CEPH de forma clara e sucinta, identificando a parte do protocolo a ser modificada e suas justificativas. Lembramos que esta modificação necessitará de aprovação ética do CEPH antes de ser implementada. De acordo

Endereço: Av. Prof. Mello Moraes, 1721 - BI. "G" sala 27

Bairro: Cidade Universitária CEP: 05.508-030

UF: SP Município: SAO PAULO

Telefone: (11)3091-4182

E-mail: ceph.ip@usp.br 


\section{USP- INSTITUTO DE PSICOLOGIA DA UNIVERSIDADE DE SÃO}

Continuação do Parecer: $2,380.097$

com a Res. CNS 466/12, o pesquisador deve apresentar a este CEP/SMS o relatório final do projeto desenvolvido, conforme preenchimento de Protocolo disponível na página do Comitê de Ética em Pesquisa com Seres Humanos do IPUSP, do site do IPUSP. Em seguida, o protocolo preenchido deverá ser enviado ao CEPH pela Plataforma Brasil, ícone Notificação, logo que o mesmo estiver concluído.

Este parecer foi elaborado baseado nos documentos abaixo relacionados:

\begin{tabular}{|c|c|c|c|c|}
\hline Tipo Documento & Arquivo & Postagem & Autor & Situação \\
\hline $\begin{array}{l}\text { Informações Básicas } \\
\text { do Projeto }\end{array}$ & $\begin{array}{l}\text { PB_INFORMAÇÕES_BÁSICAS_DO_P } \\
\text { ROJETO 1023569.pdf }\end{array}$ & $\begin{array}{c}08 / 11 / 2017 \\
09: 46: 50 \\
\end{array}$ & & Aceito \\
\hline $\begin{array}{l}\text { Projeto Detalhado / } \\
\text { Brochura } \\
\text { Investigador }\end{array}$ & Projeto_Separacao_Gemeos_final.pdf & $\begin{array}{c}08 / 11 / 2017 \\
09: 46: 29\end{array}$ & Emma Otta & Aceito \\
\hline Folha de Rosto & folha_rosto_separacao_assinado.pdf & $\begin{array}{c}06 / 11 / 2017 \\
17: 44: 40\end{array}$ & Emma Otta & Aceito \\
\hline $\begin{array}{l}\text { Declaração de } \\
\text { Pesquisadores }\end{array}$ & declaracao_separacao.pdf & $\begin{array}{c}06 / 11 / 2017 \\
17: 44: 30 \\
\end{array}$ & Emma Otta & Aceito \\
\hline $\begin{array}{l}\text { Declaração de } \\
\text { Instituição e } \\
\text { Infraestrutura }\end{array}$ & infraestrutura_separacao.pdf & $\begin{array}{c}06 / 11 / 2017 \\
17: 44: 12\end{array}$ & Emma Otta & Aceito \\
\hline $\begin{array}{l}\text { TCLE / Termos de } \\
\text { Assentimento / } \\
\text { Justificativa de } \\
\text { Ausência }\end{array}$ & TCLE_gemeos_online_separacao.pdf & $\begin{array}{c}01 / 11 / 2017 \\
15: 48: 34\end{array}$ & Emma Otta & Aceito \\
\hline
\end{tabular}

Situação do Parecer:

Aprovado

Necessita Apreciação da CONEP:

Não

SAO PAULO, 13 de Novembro de 2017

Assinado por:

Helena Rinaldi Rosa

(Coordenador)

Endereço: Av. Prof. Mello Moraes, 1721 - BI. "G" sala 27

Bairro: Cidade Universitária CEP: $05.508-030$

UF: SP Município: SAO PAULO

Telefone: (11)3091-4182

E-mail: ceph.ip@usp.br 